\title{
Vegetation, Substrate, and Eolian Sediment Transport at Teesto Wash, Navajo Nation, 2009-2012
}

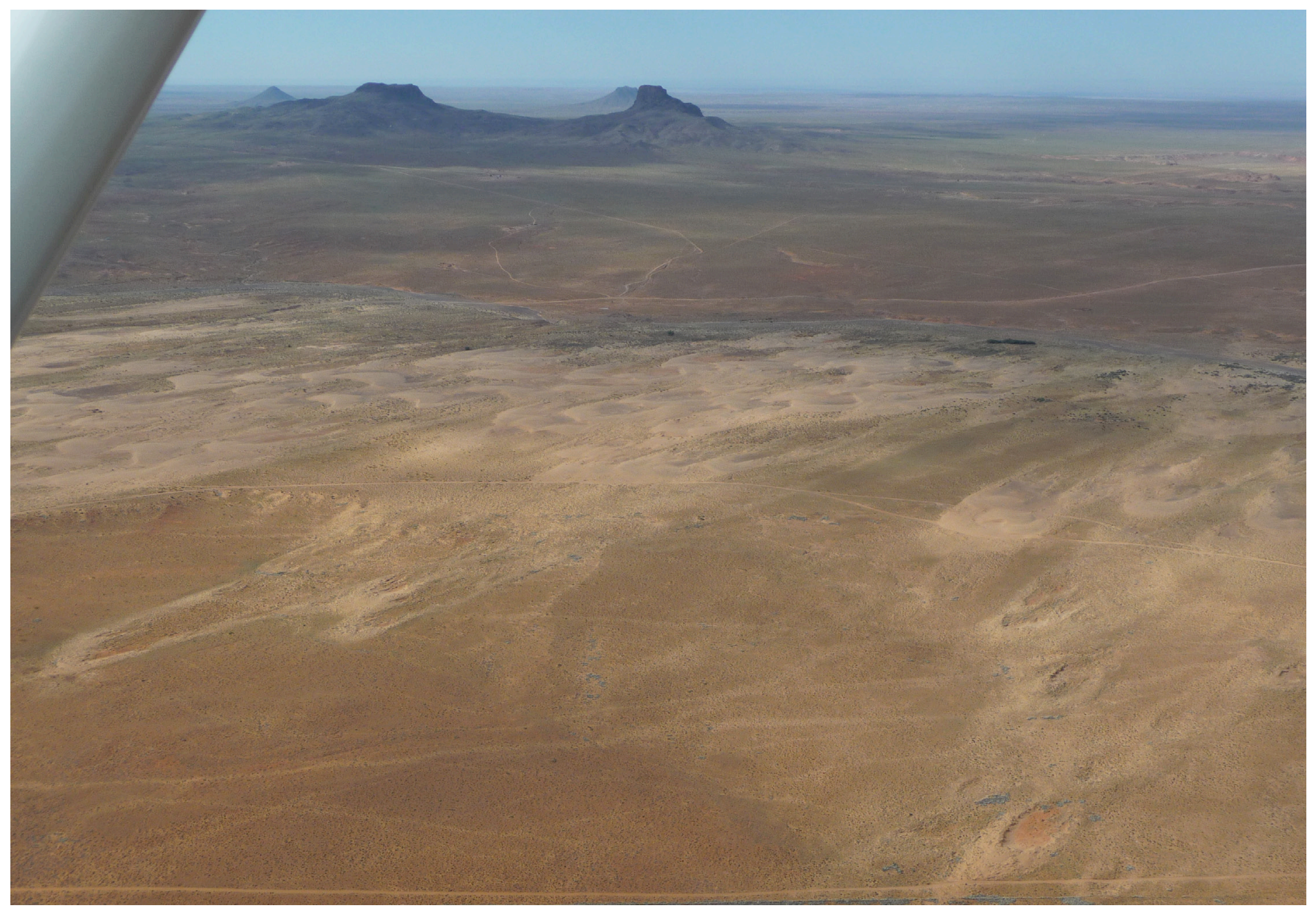

Scientific Investigations Report 2012-5095 
FRONT COVER:

Aerial photograph taken in April 2012 of Teesto Wash, Navajo Nation, approximately 45 miles north of Winslow, Arizona. View is to the southeast. Photo by Jon Mason, USGS. 


\section{Vegetation, Substrate, and Eolian Sediment Transport at Teesto Wash, Navajo Nation, 2009-2012}

By Amy E. Draut, Margaret Hiza Redsteer, and Lee Amoroso

Scientific Investigations Report 2012-5095

U.S. Department of the Interior

U.S. Geological Survey 


\section{U.S. Department of the Interior \\ KEN SALAZAR, Secretary \\ U.S. Geological Survey \\ Marcia K. McNutt, Director}

U.S. Geological Survey, Reston, Virginia: 2012

For product and ordering information:

World Wide Web: http://www.usgs.gov/pubprod

Telephone: 1-888-ASK-USGS

For more information on the USGS-the Federal source for science about the Earth, its natural and living resources, natural hazards, and the environment:

World Wide Web: http://www.usgs.gov

Telephone: 1-888-ASK-USGS

Suggested citation:

Draut, A.E., Redsteer, M.H., and Amoroso, L., 2012, Vegetation, substrate, and eolian sediment transport at Teesto Wash, Navajo Nation, 2009-2012: U.S. Geological Survey Scientific Investigations Report 2012-5095, 71 p.

Any use of trade, product, or firm names is for descriptive purposes only and does not imply endorsement by the U.S. Government.

Although this report is in the public domain, permission must be secured from the individual copyright owners to reproduce any copyrighted material contained within this report. 


\section{Contents}

Abstract
Introduction.
Methods.
Vind, Precipitation, and Sediment-Transport Measurements
Results
Discussion
Implications for the Rocky Mountains Snowpack and Substrate Measurements
References Cited.
Appendix 1. Supplementary Information

\section{Figures}

1. Map of the Southwestern United States, showing the location of the study area ...................2

2. Trends in precipitation and temperature on the Navajo Nation.............................................

3. Photographs of wind-dominated landscapes on the southern Navajo reservation near the study area in October 2008............................................................................

4. Photographs of the weather station, sand traps, and vicinity of study site 7 ..........................5

5. Scale diagram of "pod" configuration used to measure vegetation and substrate .................6

6. Eolian sediment mobility and transport, wind speed, and rainfall measured at study site 7 in 2009 and 2010...................................................................................

7. Eolian sediment mobility and transport, wind speed, and rainfall measured

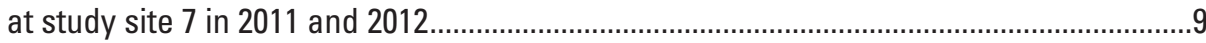

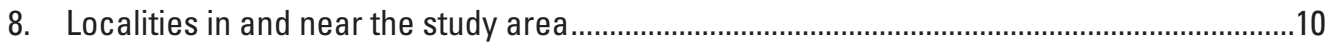

9. Variations in vegetation abundance and species assemblage .............................................10

10. Vegetation cover by study site, showing abundance in March and August

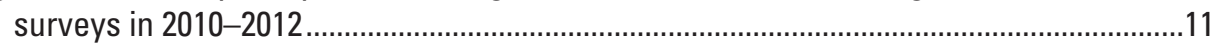

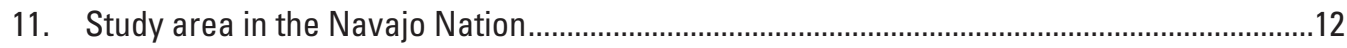

12. Substrate composition within circular plots of each pod in March 2010-March 2012.........14

13. MODIS (Moderate Resolution Imaging Spectroradiometer) satellite image, showing eolian dust plumes that originated in northeastern Arizona, within the Navajo Nation, on the afternoon of May 29, 2011...

14. Particle-size data for 24 selected samples collected in Big Spring Number Eight

(BSNE) sediment traps within the study area. 


\section{Tables}

1. Plant varieties identified in the study area near Teesto Wash, Navajo Nation, Arizona.........13

2. Summary of major site characteristics measured in the study area near Teesto Wash, Navajo Nation, Arizona.

3. Vegetation cover and substrate measured in March 2010 in the study area near Teesto Wash, Navajo Nation, Arizona.

4. Vegetation cover and substrate measured in August 2010 in the study area near Teesto Wash, Navajo Nation, Arizona ...

5. Vegetation cover and substrate measured in March 2011 in the study area near Teesto Wash, Navajo Nation, Arizona

6. Vegetation cover and substrate measured in August 2011 in the study area near Teesto Wash, Navajo Nation, Arizona

7. Vegetation cover and substrate measured in March 2012 in the study area near Teesto Wash, Navajo Nation, Arizona 


\title{
Vegetation, Substrate, and Eolian Sediment Transport at Teesto Wash, Navajo Nation, 2009-2012
}

\author{
By Amy E. Draut, ${ }^{1}$ Margaret Hiza Redsteer, ${ }^{2}$ and Lee Amoroso ${ }^{2}$
}

\section{Abstract}

On the Navajo Nation, southwestern United States, warming temperatures and recent drought have increased eolian (windblown) sediment mobility such that large, migrating sand dunes affect grazing lands, housing, and road access. We present an assessment of seasonal variations in sand transport, mobility, and ground cover (vegetation and substrate) within a $0.2-\mathrm{km}^{2}$ study area near Teesto Wash, southern Navajo Nation, as part of a multiyear study measuring the effects of drought on landscape stability. Sand mobility in the study area decreased substantially as one year (2010) with near-normal monsoon rainfall somewhat abated a decade-long drought, temporarily doubling vegetation cover. The invasive annual plant Russian thistle (Salsola sp.), in particular, thrived after the monsoon rains of 2010. Vegetation that grew during that year with adequate rain died off rapidly during drier conditions in 2011 and 2012, and the proportion of bare, open sand area increased steadily after summer 2010. We infer that isolated seasonal increases in rainfall will not improve landscape stability in the long term because sustained increase in perennial plants, which are more effective than annual plants at stabilizing sand against wind erosion, requires multiple consecutive seasons of adequate rain. On the basis of climate projections, a warmer, drier climate and potentially enhanced sediment supply from ephemeral washes may further increase eolian sediment transport and dune activity, worsening the present challenges to people living in this region. Connections between climate, vegetation cover, and eolian sediment erodibility in this region also are highly relevant for studies in other regions worldwide with similar environmental characteristics.

\section{Introduction}

The Navajo Nation, comprising the largest tribal reservation within the United States (fig. 1), is presently restricted to arid and semiarid lands within the Navajo ancestral homeland.
These lands have been stressed by drought, land-use practices, and rapid population growth during the 20th century. As in many other Native American communities, the Navajo people face economic disadvantages and, owing to livestock-management regulations and cultural ties, cannot readily relocate either their grazing lands or settlements (Redsteer and others, 2010a). Among the environmental challenges to the Navajo Nation are shifting vegetation patterns, including the spread of invasive species, and eolian (windblown) sediment mobility. Warming temperatures and[recent drought (fig. 2) have contributed to reduced streamflow and vegetation loss. These factors have increased eolian sediment mobility such that regional duststorms are common and large, migrating sand dunes now affect grazing lands, housing, and transportation (Redsteer and others, 2011). This report presents recent sediment-transport and vegetation measurements in order to elucidate and quantify some of the factors affecting landscape stability and sand mobility on the Navajo Nation, as part of a study of the effects of drought in this region. In addition to affecting the quality of life for regional residents, eolian sediment mobility in this part of the Colorado Plateau also has important implications for the longevity of the Rocky Mountains snowpack and thus for regional water supply in the western United States.

With an area of $67,000 \mathrm{~km}^{2}$ spanning parts of Arizona, New Mexico, and Utah (fig. 1), Navajo reservation lands range in elevation from 1,200 to $3,000 \mathrm{~m}$, with a regional average annual rainfall ranging from 100 to $300 \mathrm{~mm}$. As of 2010, more than 169,000 of the 332,000 Navajo tribal members were living on the reservation (Norris and others, 2010). The population grew substantially in the late 20th century; in 2000, the median age of the Navajo reservation population was 24 years, in comparison with 35.3 years for the general U.S. population (U.S. Census Bureau, 2000). The Navajo lifestyle and economy historically have been tied closely to livestock production and husbandry, but for more than a century it has been recognized that livestock populations can overgraze Navajo lands to a degree that reduces native vegetation substantially (Bailey and Bailey, 1986). Around the turn of the 20th century, regional vegetation communities began to be affected not only

\footnotetext{
${ }^{1}$ U.S. Geological Survey, Pacific Coastal and Marine Science Center, Santa Cruz, CA 95060.

${ }^{2}$ U.S. Geological Survey, Flagstaff Science Center, Flagstaff, AZ 86001.
} 
by overgrazing but also by the Eurasian annual plant Russian thistle (Salsola spp.), which spreads quickly on loose, sandy soils such as those that occur over much of the Navajo Nation. In its dry form known as tumbleweed, Russian thistle disperses great distances aided by wind and is one of the most widespread invasive plants on Navajo lands today.

Precipitation occurs bimodally in the southwestern United States, during winter storms (December-March) and the North American monsoon season (July-September), with 45 percent of annual precipitation on Navajo lands falling during the summer monsoon (Redsteer and others, 2010a). These two wet seasons are separated by a dry, windy spring (for example, Hack, 1941; Draut and Rubin, 2006; Jewell and Nicoll, 2011; Munson and others, 2011). For most of the past century precipitation has been declining in Navajo lands (fig. 2) and climate has been warming more rapidly in the southwestern United States than in many other regions of North America, resulting in associated ecologic changes (Westerling and others, 2006; Seager, 2007a; Weiss and others, 2009). Declining precipitation, a shift from snowfall to rainfall, and increased potential evapotranspiration have contributed to a reduction in surface water on Navajo lands. At least 30 streams and lakes that were perennial in the 1920s are now dry or ephemeral (Redsteer and others, 2010a). Climate models project increasingly drier and warmer conditions throughout the southwestern United States for the coming decades (Seager and others, 2007b; Solomon and others, 2007; Dominguez and others, 2010).

Eolian sand covers much of the Navajo lands (Hack, 1941). Nearly a third of the Navajo reservation has loose, sandy soil that the wind winnows and shapes into dunes; the Four Corners region of the Colorado Plateau contains the largest area of eolian sand dunes within the southwestern United States (Muhs and others, 2003; Muhs and Been, 2004; Redsteer and others, 2010a). New sand dunes have formed and enlarged substantially on Navajo lands since the mid-20th century in areas with sandy soils and sparse vegetation (Redsteer and others, 2011). Particularly after a 1950s drought, loss of perennial streamflow left riverbeds dry, providing a source from which the wind mobilizes sediment (Redsteer and others, 2010b). Aerial photographs show evidence for eolian sand transport downwind of many streambeds in the Navajo Nation, commonly forming well developed dune fields (fig. $1 B$ ) similar to the so-called "source-bordering dunes" that occur

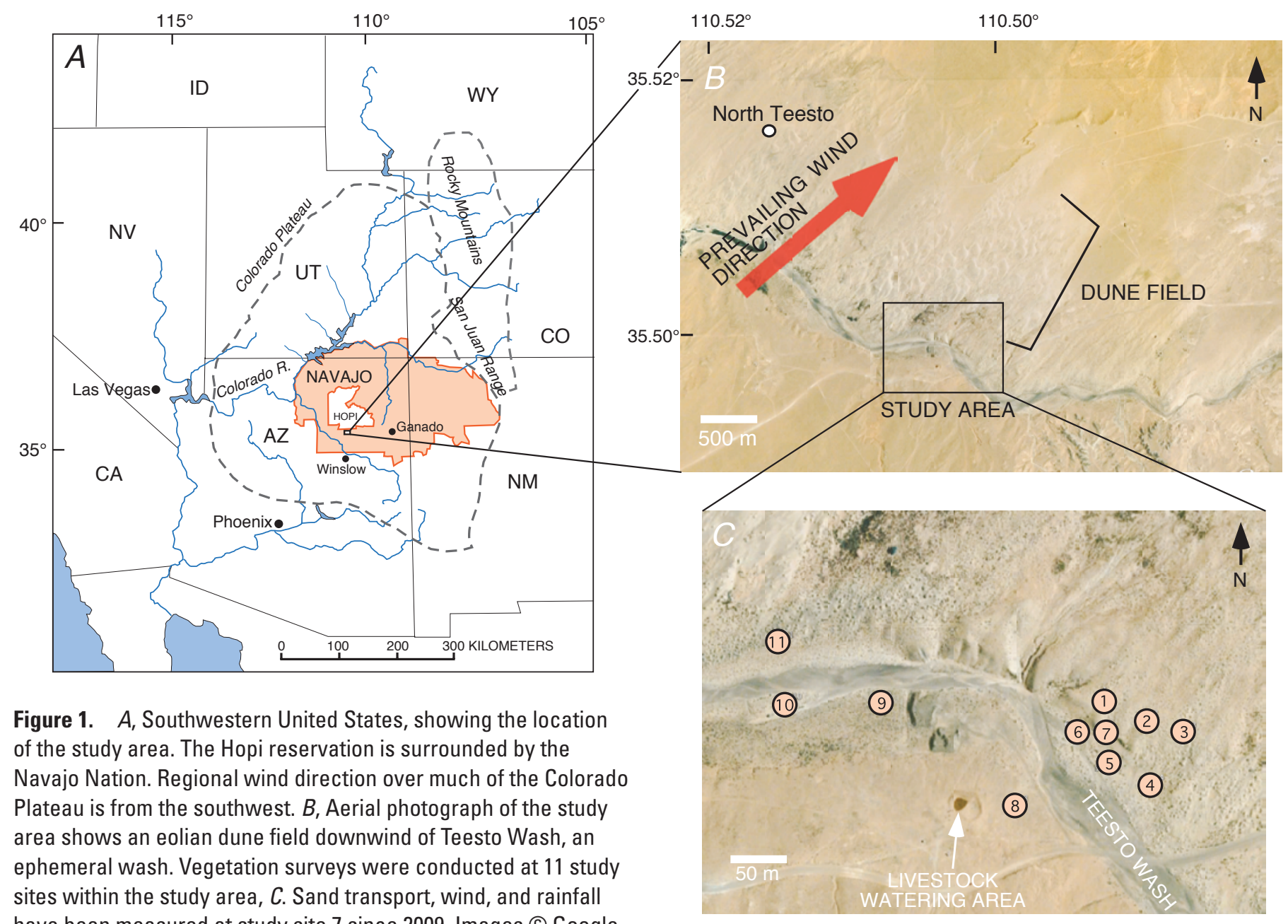

have been measured at study site 7 since 2009. Images (C) Google Earth, 2007. 

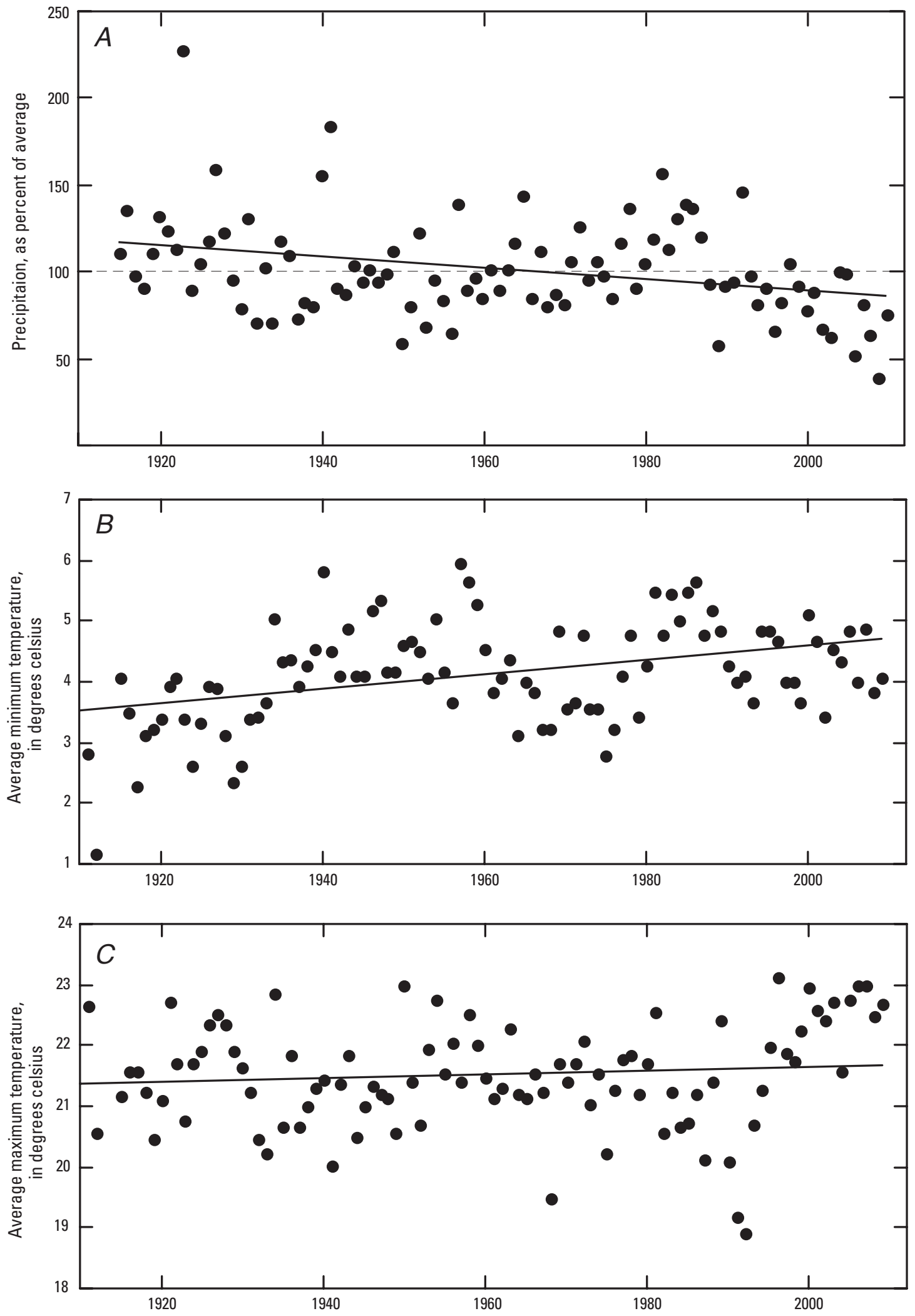

Figure 2. Trends in precipitation and temperature on the Navajo Nation. $A$, Rainfall on the southern Navajo reservation, as a percentage of the 1915-2010 average, using combined data from Winslow and Ganado, Arizona, the two weather stations nearest the study area with long-term records (see fig. $1 A$ for locations). $B$, Average monthly minimum temperature measured at Winslow, Arizona, from 1915 to 2010. C, Average monthly maximum temperature measured at Winslow, Arizona, from 1915 to 2010 . Best-fit linear regressions are shown. 
immediately downwind of desert streambeds in other dryland regions globally (Bullard and McTainsh, 2003). Eolian sediment mobilization and dune activation commonly occur in response to climatic change, not only on Navajo lands but also in other field settings (Muhs and Holliday, 1995; Lancaster, 1997; see reviews by Bullard and Livingstone, 2002, Bullard and McTainsh, 2003; and Cornelis, 2006). The environmental effects of increased eolian sediment mobility and transport
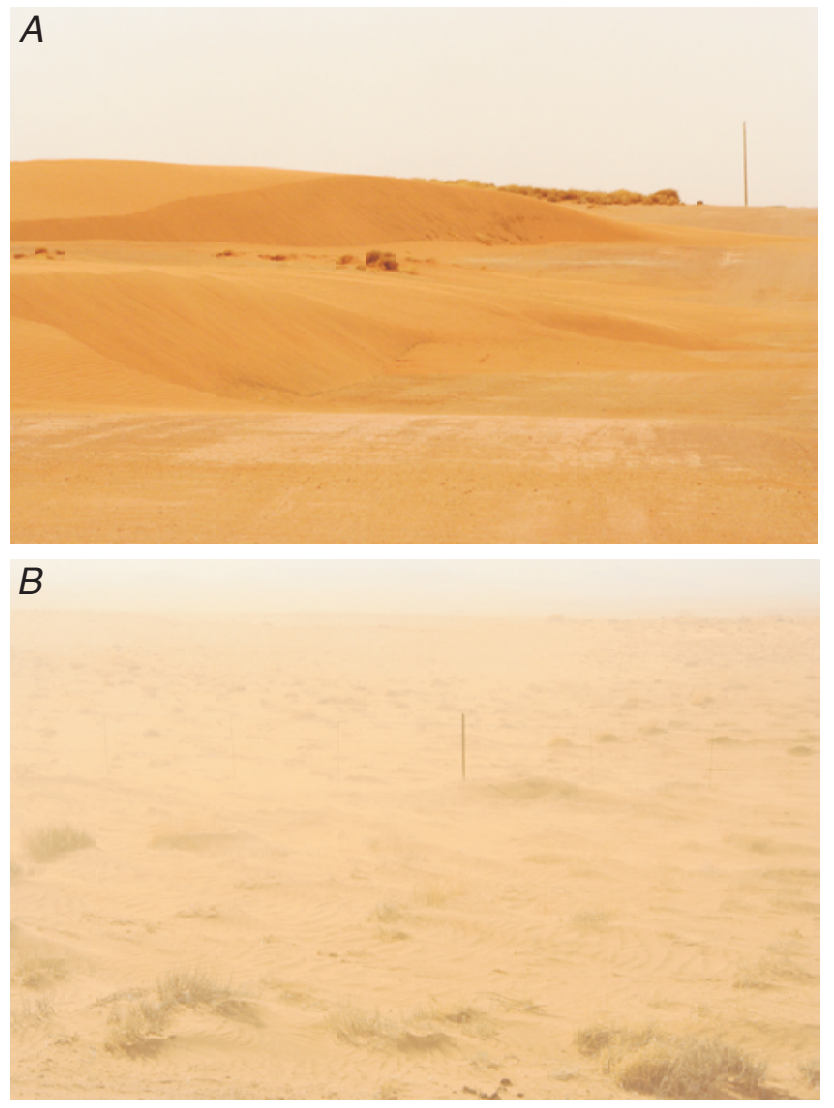

C

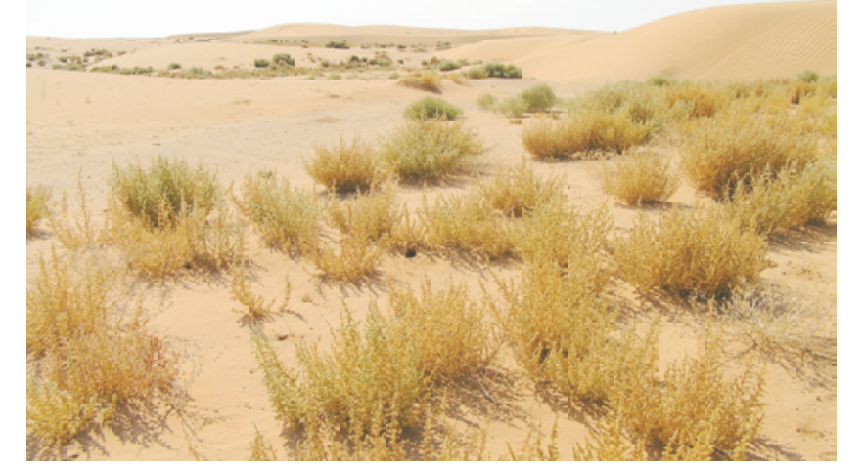

Figure 3. Wind-dominated landscapes on the southern Navajo reservation near the study area (fig. 1) in 0ctober 2008. $A$, Dunes migrating from left to right across a road. $B$, Haze from airborne dust in an area where sandy soils are readily mobilized by wind. Fencepost in center of photograph is $1 \mathrm{~m}$ high. $C_{\text {, }}$ Nonnative Russian thistle plants dominating vegetation in an eolian dune field. during dry intervals are substantial and affect many residents of the Navajo Nation - airborne dust reduces air quality, causing health risks, and sand dunes that can migrate as fast as tens of meters per year frequently impede road access and have even destroyed houses (fig. 3; Redsteer and others, 2010a, b).

Because the Navajo lands are fairly remote, quantitative measurements of environmental parameters are scarce. The U.S. Geological Survey (USGS) began a pilot drought-monitoring program there in 2005 that deployed new weather stations. Several years later, this study was expanded to measure eolian sediment transport and vegetation. We present some results of this monitoring study, with the goal of understanding the influence of seasonal weather patterns on eolian sediment mobility, and vegetation type and abundance. Eolian sediment mobility is a useful indicator of dryland environmental conditions - the air-quality and landscape-stability issues it represents are vital to evaluating the habitability of the Navajo reservation and the longevity of the Rocky Mountains snowpack as the 21 st-century climate becomes warmer and drier.

\section{Methods}

Wind, rainfall, eolian sediment transport, and ground cover (vegetation and substrate) were measured between 2009 and 2012 in a study area that, though small in comparison with the vast size of the Navajo Nation, is representative of where many settlements are situated. Some 15,000 to 20,000 Navajo people reside on landscapes with ground cover similar to that of the $0.2-\mathrm{km}^{2}$ study area - sandy soils on and near dune fields and an ephemeral wash, in an area with livestock use and occasional offroad-vehicle traffic (fig. 1C).

\section{Wind, Precipitation, and Sediment-Transport Measurements}

Wind velocity, precipitation, and eolian sediment transport were measured beginning in March 2009 at the site marked "7" in figure 1C. A weather station and sand traps were deployed approximately $10 \mathrm{~m}$ apart, each surrounded by fenced enclosures to prevent damage by livestock; the instrument deployments are shown in figure 4 . The weather station included an Onset wind speed and direction sensor (spinningcup anemometer with wind vane) mounted on a tripod at a height of $2 \mathrm{~m}$ above the bed. This anemometer measured wind speed with $0.2-\mathrm{m} / \mathrm{s}$ resolution, and wind direction as vector components with a resolution of $1.4^{\circ}$ and an accuracy range of $\pm 5^{\circ}$. An Onset tipping-bucket rain gage measured precipitation with a resolution of $0.2 \mathrm{~mm}$ and an accuracy of \pm 1 percent. Wind and precipitation measurements were recorded on an Onset ${ }^{\mathrm{TM}}$ digital datalogger. Precipitation was recorded as 4-minute total rainfall amounts, and wind speed and wind direction every 4 minutes as 4-minute averages using a 3-s sampling interval. 
Windblown sediment was collected in four passivesampling Big Spring Number Eight (BSNE) traps (Fryrear, 1986) mounted on a vertical pole $10 \mathrm{~m}$ upwind of the weather station (fig. 4). Each trap was equipped with a vane that turned the sampler into the wind. The bases of the 5-cm-tall trap orifices were set at heights of $0.1,0.4,0.7$, and $1.0 \mathrm{~m}$ above the ground, so placed because most eolian sediment transport occurs within $1 \mathrm{~m}$ of the bed (Anderson and Hallet, 1986; Sterk and Raats, 1996; Zobeck and others, 2003). Wind-tunnel studies (Goossens and others, 2000) indicate a BSNE sand-trap efficiency range of 70-130 percent for the wind velocities and sediment grain sizes measured at this study site. An efficiency less than 100 percent indicates that airflow is directed away from the orifice, such that the trap undersamples windblown sediment, whereas an efficiency greater than 100 percent indicates that air flow is directed into the trap, over sampling windblown sediment. A conservative efficiency range of 70-130 percent was used to estimate error in the sand-transport data reported here because it is the best available for this type of bulk sand-transport data.

Approximately every 4 weeks, sediment was emptied from the traps, oven-dried overnight at $65^{\circ} \mathrm{C}$ in the USGS laboratory in Santa Cruz, California, and then weighed. Organic matter was not removed from sediment samples before weighing, because the organic-matter proportion of the sample was negligible. Sediment-transport rates were calculated by dividing the total mass of sediment in the traps by the number of days over which it accumulated. To avoid introducing uncertainty, measured sediment fluxes were not extrapolated down to the bed; thus, although measurements do not account for the absolute total mass flux, trends in relative amounts of transport over time still are apparent. Sediment-transport rates were normalized to show sediment mobility without the effects of varying wind speed over different time intervals; to normalize the data, each sediment-flux measurement was divided by the cumulative flux predicted for that interval by the Dong and others (2003) transport equation. This formulation, a modification of that proposed by O'Brien and Rindlaub (1936), was chosen because it treats wind strength as a function of velocity rather than shear velocity; to extrapolate shear velocity from wind velocity measured at only one height would introduce additional, unwanted uncertainty.

Particle-size analysis was performed on 24 sediment samples that were selected because they represented eolian sediment transport during the spring windy seasons of 2009, 2010, and 2011. Samples were analyzed at the U.S. Geological
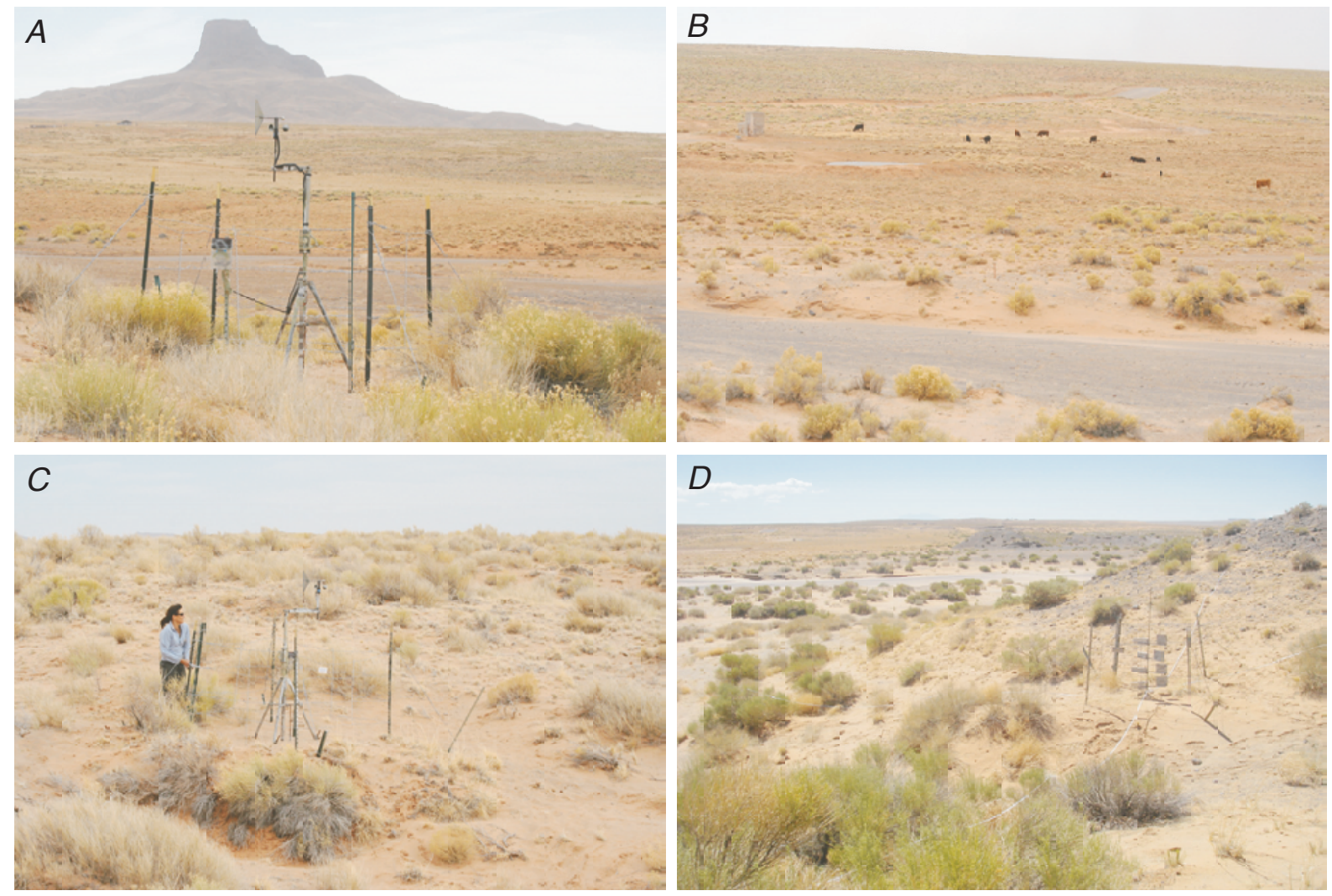

Figure 4. Weather station, sand traps, and vicinity of study site 7 (see fig. $1 C$ for location). $A$, Weather station, with anemometer and wind-direction sensor mounted on instrument tripod $2 \mathrm{~m}$ above ground. The rain gage is on the left; fenced enclosure surrounds the station. View is southeastward across Teesto Wash. $B$, Cistern and cattle near study site 8, viewed from study site 7 across Teesto Wash. C, Weather station at study site 7. View northeastward. D, Sand-trap deployment at study site 7. Four Big Spring Number Eight (BSNE) sand traps were mounted on a vertical pole and surrounded by a fenced enclosure. White measuring tape along ground was used to measure gap length during ground-cover surveys. View southwestward. 
Survey's Geology and Environmental Change Science Center laboratory in Denver, Colorado. Bulk samples were split with a chute splitter and treated with 30 percent aqueous hydrogen peroxide to remove organic matter. Sodium hexametaphosphate was added to all samples as a deflocculant, and the samples were shaken on a shaker table for 4 hours to ensure deflocculation of clay material. Grain size was determined by using a Malvern Mastersizer 2000 laser analyzer. Each sample was introduced into an aqueous medium and pumped through the laser analyzer for particle-size measurements.

\section{Vegetation and Substrate Measurements}

Vegetation and substrate cover were measured once at each of the 11 study sites (fig. $1 C$ ) during each of five surveys, in spring and fall 2010, spring and fall 2011, and spring 2012, in a layout of circles and linear transects referred to here as a "pod" (Draut and Gillette, 2010; Draut, 2011). As shown in figure 5, each pod consisted of two orthogonal transects marked out with measuring-tape reels (one oriented parallel and another oriented perpendicular to the prevailing wind direction) and five 3-m-radius circles outlined in the sand (one in the center of the pod and another at the end of each of the four transects).
Along each of the transects within a pod, gap lengths were measured where the measuring tape crossed bare, open sand without rocks, biologic soil crust, leaf litter, or overhanging plant canopy. Biologic soil crust, a common component of desert ecosystems, consists of cyanobacteria living symbiotically with lichen, mosses, fungi, and algae (Belnap and others, 2001; Belnap and Lange, 2003). This method of measuring gap length was modified from that used by Herrick and others (2005), with their criteria to define plant-canopy gaps, as a means to measure the spacing and abundance of roughness elements, vegetation, and patches of biologic crust that could reduce eolian sediment mobility (Ash and Wasson, 1983; Leys and Eldridge, 1998; Belnap and Lange, 2003; Goossens, 2004). The proportion of bare, open sand in the dune field then was estimated for each of the 11 study sites by adding all the measured gap lengths from each transect to compile a cumulative gap-length measurement representing total gap length as a percentage of total transect length. Gap lengths between plant bases (basal gap length; Herrick and others, 2005) also were measured.

Within each of the five circles in a pod, the percentage of vegetation cover was measured, as were the types of substrate in which the plants were growing. Vegetation was identified to species level wherever possible, using the names and

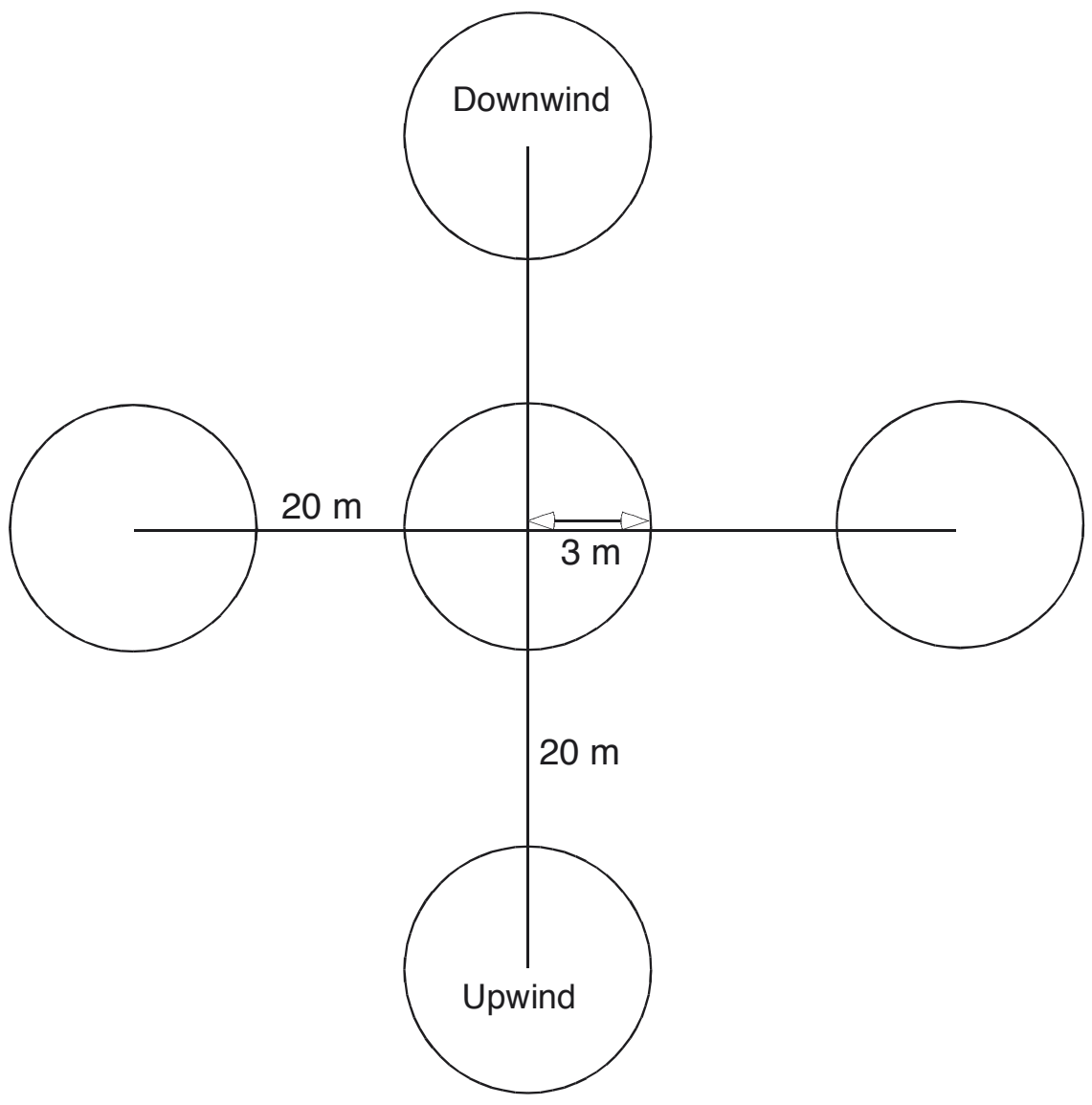

Figure 5. Scale diagram of "pod" configuration used to measure vegetation and substrate. 
descriptions provided by Taylor (1992), Williams (2000), and Huisinga and others (2006), supplemented with identifications made by experts on plant communities of the Navajo Nation area (L. Begay and A. Clifford, oral commun., 2009) and maintaining consistency with the U.S. Department of Agriculture plant database (http://plants.usda.gov, accessed June 20, 2012). Where species identification was uncertain, plants were identified by their family or genus, or by designation as annual or perennial grass, forb, or shrub. Substrates were divided into four categories: open sand, biologic soil crust, leaf litter, and rock. To estimate the percentage of cover of both plants and substrate, a disc of known size was compared with the area covered by a plant, rock, patch of soil crust, or other object of interest. The disc (20-cm radius) has an area $\left(0.13 \mathrm{~m}^{2}\right)$ approximately 0.5 percent of the circle size studied $\left(28.3 \mathrm{~m}^{2}\right)$. By holding a disc of known radius above plants or patches of biologic crust to estimate their size and percentage of cover, researchers avoided disturbing the ground surface unnecessarily, as would happen from handling plants or placing measuring devices directly on sensitive, soil-encrusted ground. The uncertainty in this method of ground-cover measurement is estimated conservatively to be no more than 5 percent, on the basis of the consistency of measurements made during repeated visits, within the same season, to several test circles. Annual variations in plant cover were minimized by repeating the surveys of each season within a week of the dates on which the survey had been conducted in the previous year; thus, the three March surveys (2010, 2011, and 2012) were conducted between March 12 and 19, and the two August surveys on August 8 and 9 (2010 and 2011).

Vegetation that appeared to be dead but that was still rooted in the ground was included in the category of vegetation cover, whereas dead vegetation no longer rooted in the ground was classified as litter substrate. Vegetation cover was considered to be dead if one specimen of a particular plant remained brown and did not bloom during the time when other plants of its species were green and blooming, or if some part of a shrub was seen to be brown while another part of the same shrub was green. With those two exceptions of circumstance, vegetation cover was assumed to be living; especially during winter, perennial grasses and shrubs are dormant and so do not appear green.

\section{Results}

Seasonal patterns in wind, precipitation, and sediment transport varied substantially throughout the study interval (figs. 6, 7). Because the anemometer and datalogger deployed in the study area malfunctioned several times during 2009 and 2010 , two intervals during those years are represented in figure 6 by using data collected $1.5 \mathrm{~km}$ northwest of the study site at another weather station with a configuration similar to that at the study site (North Teesto, fig. 1B). Wind and rain data from North Teesto are plotted for year days 202-314 (July 21 to Nov. 10) in 2009, and North Teesto wind data for year days 91-219 (Apr. 1 to Aug. 7) in 2010, in figure 6.

As is common in this region, wind velocity (accompanied by dry conditions) and corresponding eolian sediment transport were greatest during spring. Sediment-transport rates in spring 2009 and 2010 were approximately 10 times higher than in other seasons, and springtime sand mobility in those years was approximately 10 to 100 times greater than in other seasons (fig. 6). Sediment transport and mobility in 2011 were markedly lower than in the preceding 2 years, particularly during spring (fig. 7), observations consistent with a large increase in vegetation cover during 2010, as discussed below.

During the study interval, hydrologic conditions in the southwestern United States spanned several years in the La Niña phase of the El Niño-Southern Oscillation (ENSO) cycle $(2009,2011,2012)$ and one weak El Niño year (2010). In 2009, Arizona recorded its fourth-driest year in 117 years, and the preceding 3 years also had been abnormally dry (National Climatic Data Center, 2012). Several wetter seasons followed in 2010, which was Arizona's 85th-driest year on record with above-normal rainfall state wide, although northeastern Arizona received below-average rainfall (fig. 2). Dry conditions returned again in 2011, a year that received below-average rainfall and was the $23 \mathrm{~d}$ driest on record in Arizona. Rainfall in the study area occurred predominately during the summer monsoon and winter storm seasons, although, unusual for that time of year, $15 \mathrm{~mm}$ of rain also fell on May 21, 2009. The largest rain event measured during the study interval was an intense monsoon storm on the evening of July 31, 2010, that delivered $38 \mathrm{~mm}$ of rain, $29 \mathrm{~mm}$ of which fell within 20 minutes. That rain event produced the only known discharge in Teesto Wash during the study interval. Using the slopearea method retroactively to gage discharge in Teesto Wash within the study area, we estimated the flow from that event to have been approximately $10 \mathrm{~m}^{3} / \mathrm{s}$. Runoff caused by the July 31,2010 , storm incised more than $1 \mathrm{~m}$ into nearby graded gravel roads and formed gullies within eolian sand (fig. 8) that remained visible for several months.

Vegetation abundance and species assemblage varied substantially between 2010 and 2012, both seasonally and longer term (figs. 9-11; tables 1-7). Vegetation assemblages at the study sites typically contained from 5 to 15 different plant species (tables 1,3-7). Native plants that commonly occur in the study area included perennial bunchgrasses, such as Indian ricegrass (Oryzopsis hymenoides, also known as genus Achnatherum), sandhill muhly (Muhlenbergia pungens), galleta grass (Pleuraphis jamesii), and several species of dropseed (Sporobolus spp.). Common native shrubs and forbs included rabbitbrush (Ericameria nauseosus), snakeweed (Gutierrezia sarothrae), Mojave indigobush (Psorothamnus arborescens), globemallow (Sphaeralcea sp.), and stickleaf (Mentzelia pumila). Less common native shrubs included saltbush (Atriplex sp.), ephedra (Ephedra sp.), and narrowleaf yucca (Yucca angustissima). In the August 2010 vegetation survey (table 4), which followed abundant monsoon rainfall, the vegetation assemblage in the study area also commonly contained the 

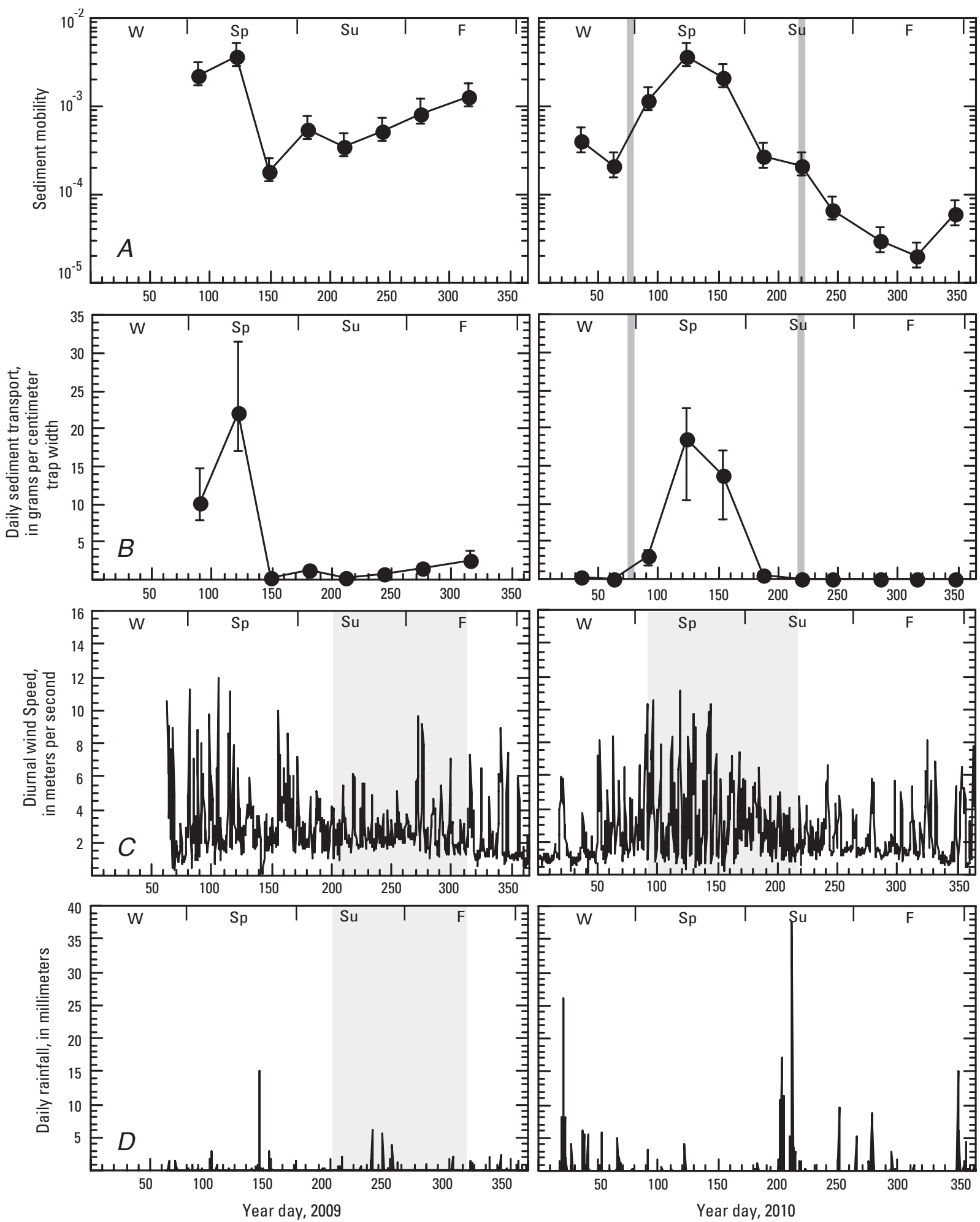

Figure 6. Eolian sediment mobility and transport, wind speed, and rainfall measured at study site 7 in 2009 and 2010 (see fig. $1 C$ for location). $A$, Sediment mobility, in dimensionless units obtained by normalizing the sediment-transport measurements plotted in figure $6 B$ against cumulative sand flux predicted for each time interval, as a function of wind speed, by the transport equation of Dong and others (2003). Gray vertical bars indicate times of vegetation surveys. $B$, Direct measurements of eolian sediment transport obtained from sampled mass collected in Big Spring Number Eight (BSNE) traps divided by the number of days over which it accumulated. Error bars factor in a 70-130-percent efficiency range for BSNE traps (Goossens and others, 2000). C, Wind speed, expressed as daytime (06:00-18:00) and nighttime (18:00-06:00) averages of 4-minute data. $D$, Daily rainfall summed from 4-minute measurements. Gray-shaded regions in figures $6 C$ and $6 D$ indicate data from a weather station at North Teesto (fig. 1) during instrument malfunction at study site 7. 

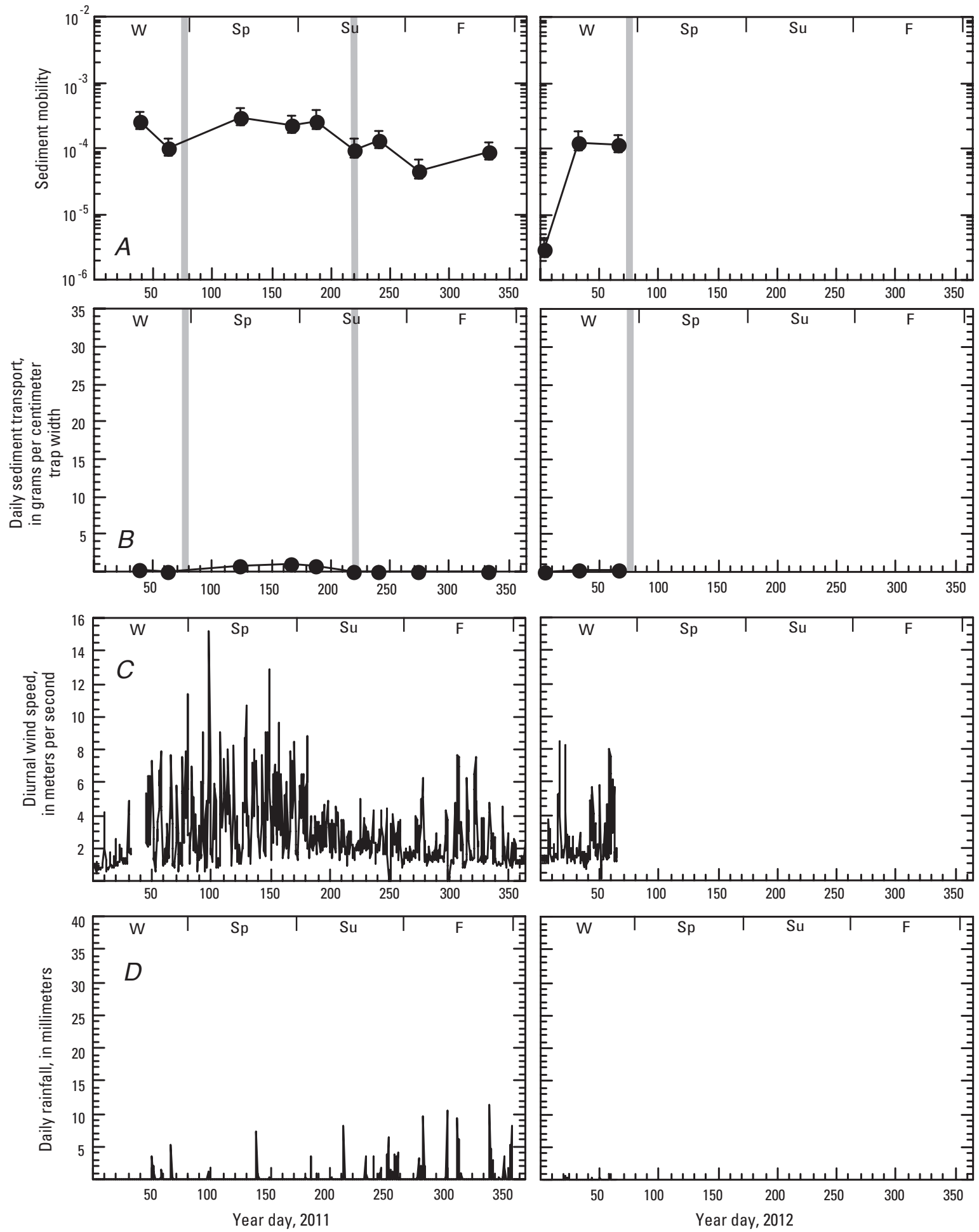

Figure 7. Eolian sediment mobility and transport, wind speed, and rainfall measured at study site 7 in 2011 and 2012. A, Sediment mobility, in dimensionless units obtained by normalizing the sand-transport measurements plotted in figure $7 B$ against cumulative sand flux predicted for each time interval, as a function of wind speed, by the transport equation of Dong and others (2003). Gray vertical bars indicate times of vegetation surveys. Note that vertical scale of figure $7 A$ encompasses one order of magnitude more than does the scale in figure $6 A$. $B$, Direct measurements of eolian sediment transport obtained from sampled mass collected in Big Spring Number Eight (BSNE) traps divided by the number of days over which it accumulated. Error bars factor in a 70-130-percent efficiency range for BSNE traps (Goossens and others, 2000). Beginning in winter 2011, sand-transport measurements probably were artificially low owing to tumbleweed accumulating at the upwind side of sand-trap enclosure. $C$, Wind speed, expressed as daytime (06:00-18:00) and nighttime (18:00-06:00) averages of 4-minute data. $D$, Daily rainfall summed from 4-minute measurements. 

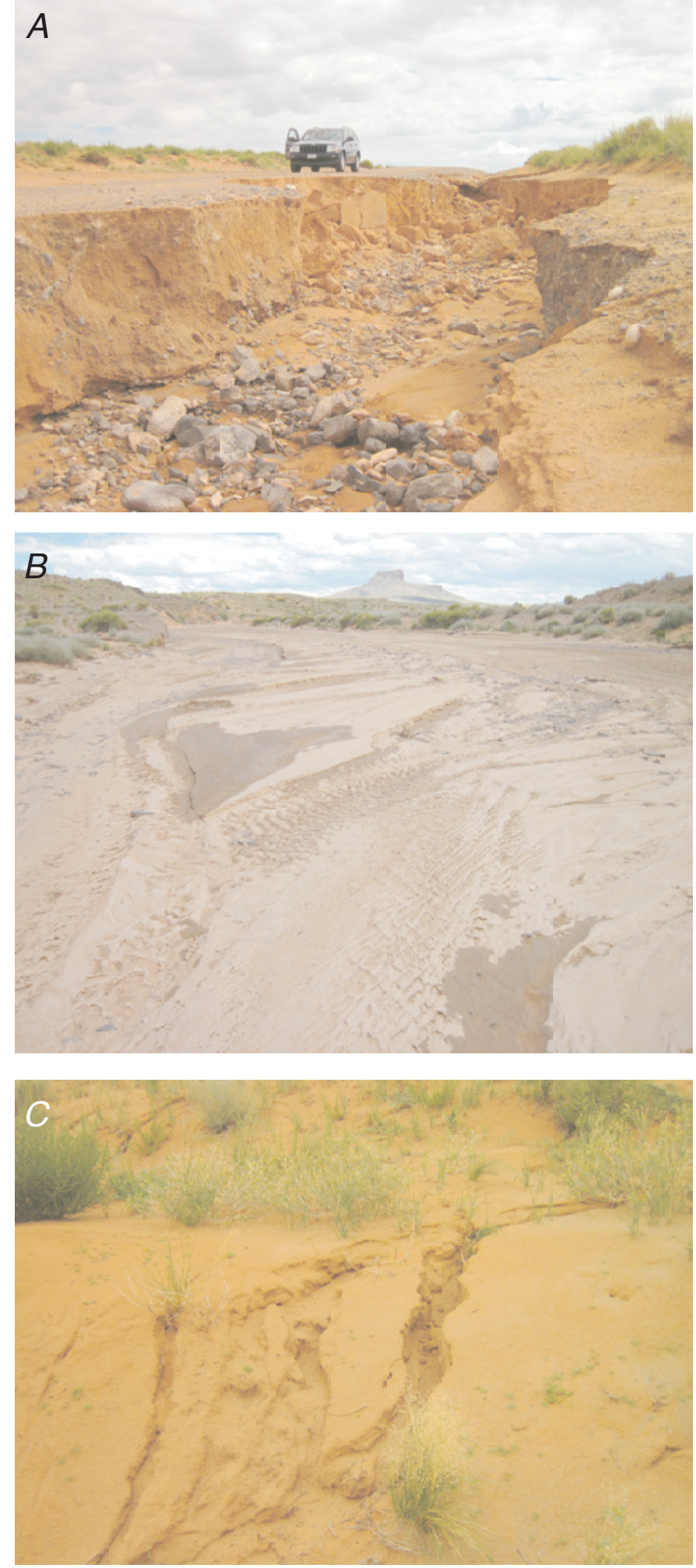

Figure 8. Localities in and near the study area (fig. 1) where an intense monsoon rainstorm occurred on the evening of July 31 , 2010. A, Gullies more than $1 \mathrm{~m}$ deep incised into a graded gravel road, approximately $0.5 \mathrm{~km}$ east of the study area. $B$, Streambed of Teesto Wash near study site 9 , with ripple structures and still-damp sediment indicating recent flow. $C$, Gullies incised into eolian sand near study site 4 .
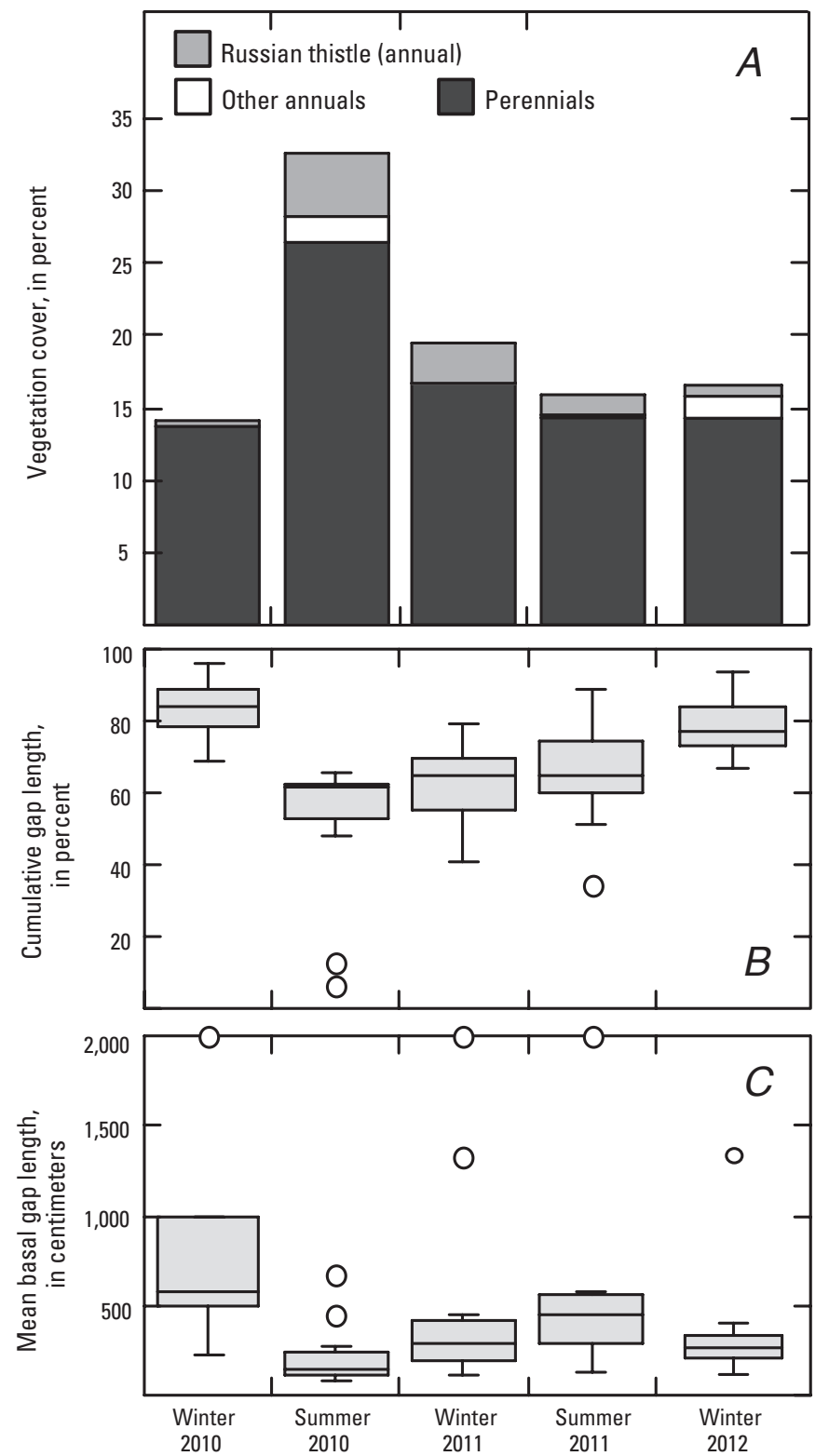

Figure 9. Variations in vegetation abundance and species assemblage. $A$, Vegetation cover, with measurements from circular plots within pods at all 11 study sites (see fig. $1 C$ for locations) combined for each of five biannual surveys. $B$, Cumulative gap length where bare, open sand was present on linear transects of each pod (percentage of total transect length). Boxes span interquartile range of data collected at all 11 study sites; horizontal line through each box is median. Circles, outlier points with values more than 1.5 times interquartile range; bars, highest and lowest non-outlier points. $C$, Mean basal gap length (distance between plant bases; Herrick and others, 2005) measured on linear transects of each pod. 

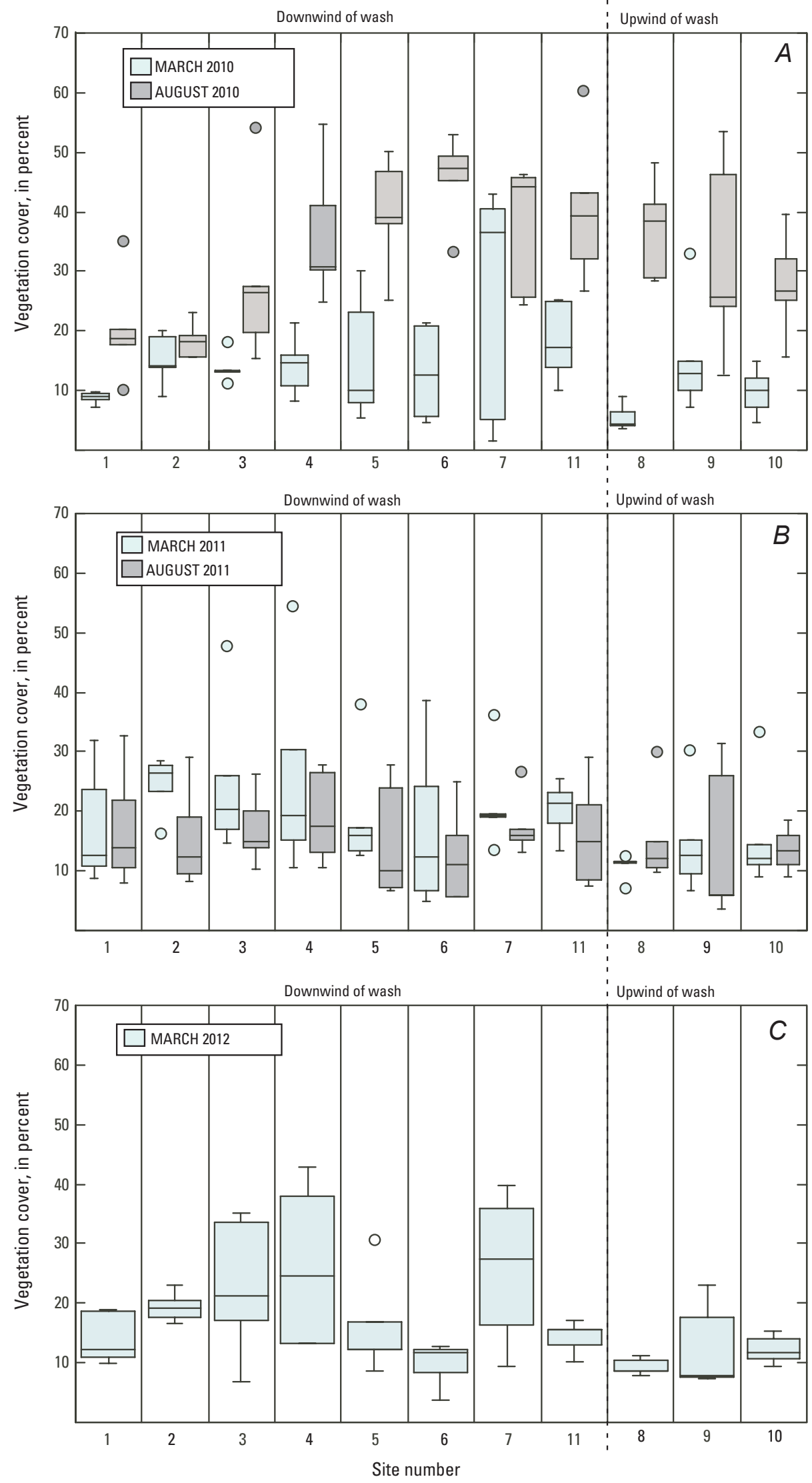

Figure 10. Vegetation cover by study site, showing abundance in March and August surveys in A, 2010, B, 2011, and C, March 2012. 

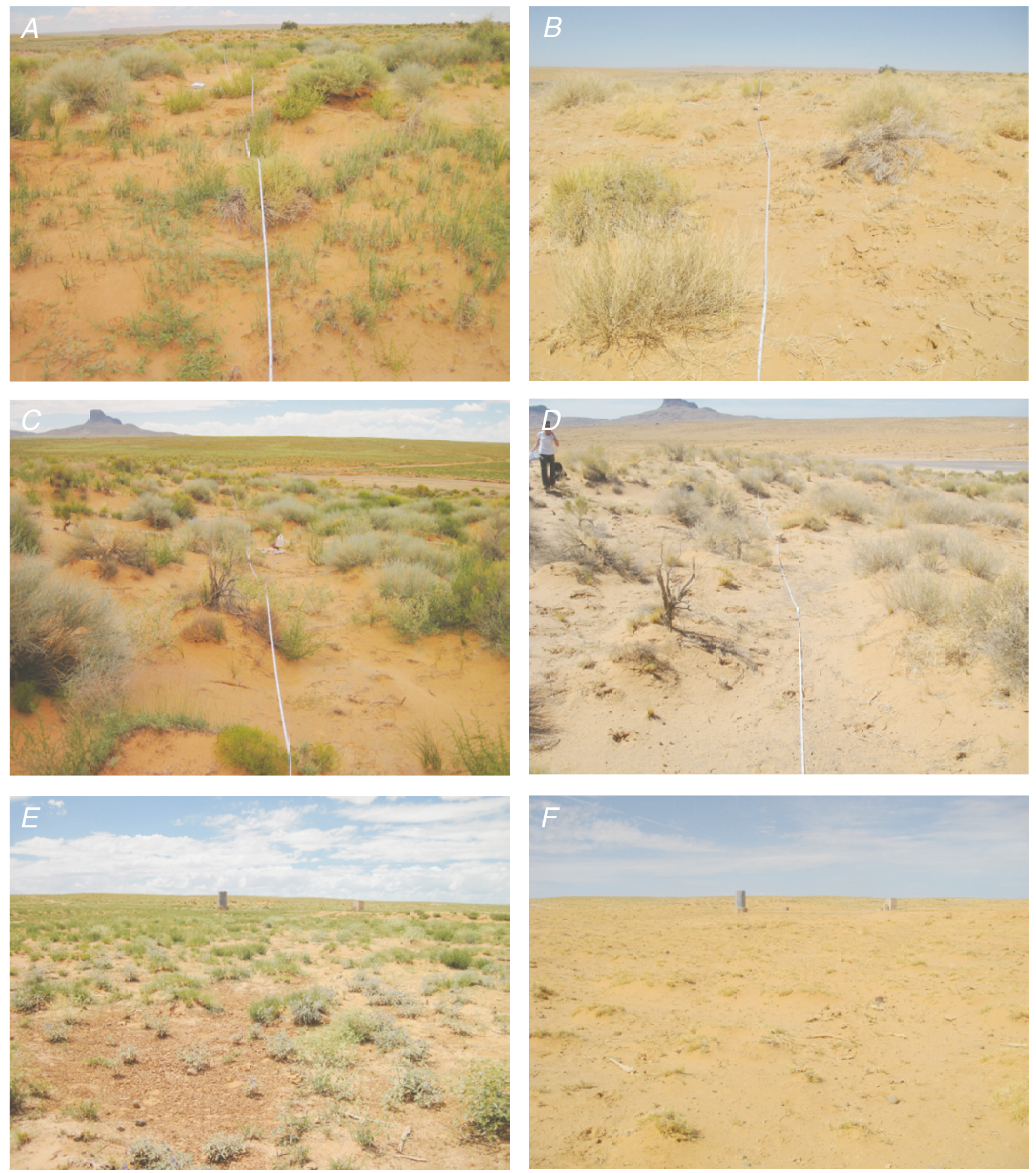

Figure 11. Study area in the Navajo Nation (fig. 1), showing contrast between August vegetation cover during a year with near-normal rainfall (2010) and a year with below-average rainfall (2011). A, Study site 1 in August 2010. B, Study site 1 in August 2011. C, Study site 3 in August 2010. D, Study site 3 in August 2011. E, Study site 8 in August 2010. F, Study site 8 in August 2011. 
annual plants desert twinbugs (Dicoria canescens), doveweed (Croton texensis), Plains spring parsley (Cymopterus acaulis), and bindweed heliotrope (Heliotropium convolvulaceum). Nonnative plants Russian thistle (Salsola sp.), an annual, and silverleaf nightshade (Solanum elaeagnifolium), a perennial, were abundant in several of the surveys, particularly in August 2010 (table 4).

Table 1. Plant varieties identified in the study area near Teesto Wash, Navajo Nation, Arizona.

[Some surveys also noted unidentified plants that are omitted from this list but were recorded as unidentified annual or perennial grasses, forbs, or shrubs]

\begin{tabular}{|c|}
\hline Alkali sacoton (Sporobolus airoides) \\
\hline Basin wildrye (Leymus cinereus) \\
\hline Bindweed heliotrope (Heliotropium convolvulaceum) \\
\hline Dicoria (Dicoria canescens) \\
\hline Doveweed (Croton texensis) \\
\hline Ephedra (Ephedra sp.) \\
\hline Galleta grass (Pleuraphis jamesii) \\
\hline Giant dropseed (Sporobolus giganteus) \\
\hline Globemallow (Sphaeralcea sp.) \\
\hline Grama grass (Bouteloua sp.) \\
\hline Greene's rabbitbrush (Chrysothamnus greenei) \\
\hline Indian ricegrass (Oryzopsis hymenoides) \\
\hline Milkvetch (Astragalus sp.) \\
\hline Milkweed (Asclepias sp.) \\
\hline Mojave indigobush (Psorothamnus arborescens) \\
\hline Narrowleaf yucca (Yucca angustissima) \\
\hline Pigweed (Amaranthus sp.) \\
\hline Plains spring parsley (Cymopterus acaulis) \\
\hline Purple three-awn (Aristida purpurea) \\
\hline Rabbitbrush (Ericameria nauseosus) \\
\hline Russian thistle (Salsola sp.) \\
\hline Saltbush (Atriplex canescens) \\
\hline Sand dropseed (Sporobolus cryptandrus) \\
\hline Sand verbena (Abronia fragrans) \\
\hline Sandhill muhly (Muhlenbergia pungens) \\
\hline Silverleaf nightshade (Solanum elaeagnifolium) \\
\hline Snakeweed (Gutierrezia sarothrae) \\
\hline Spike dropseed (Sporobolus contractus) \\
\hline Stickleaf (Mentzelia pumila) \\
\hline Unidentified aster (Asteraceae family) \\
\hline Wire lettuce (Stephanomeria pauciflora) \\
\hline
\end{tabular}

In 2010, vegetation cover increased substantially between the surveys in March and those during the summer monsoon season (August) of 2010 (figs. 9, 10; table 2). Both annual- and perennial-plant cover increased between March and August 2010, with perennial growth occurring primarily by canopy cover increase on existing plants rather than by recruitment of new plants. No similar increase occurred from winter to summer during the much drier year 2011. Plant cover decreased slightly between March and August 2011, even though warm temperatures and longer daylight hours typically favor plant growth then (fig. 9A). During the August 2011 vegetation survey, when monsoon rainfall that year had been only 14 percent of what had fallen by the same date in 2010, vegetation cover was notably less than in August 2010 (fig. 11). Changes in cumulative canopy gap length (fig. $9 B$ ) largely reflected the increase and subsequent decrease in vegetation abundance during 2010 and 2011. Substrate measurements indicated no substantial change in biologic soil crust or rock area, and little change in accumulated leaf litter that factor into the cumulative-gap-length calculation, and most study sites had $>95 \%$ sand substrate at each survey (fig. 12). Leaf litter was somewhat more abundant in 2011 than in 2010 , as expected, given the abundant vegetation in summer 2010 that had begun to die off by 2011; nevertheless, leaf litter accounted for $<3$ percent of substrate area at most sites, even in the surveys when it was most abundant. As of March 2012, vegetation cover apparently had increased slightly relative to that of summer 2011 (table 2), although the amount of increase was within the measurement uncertainty $(15.9 \pm 0.79$ percent in August 2011, in comparison with $16.5 \pm 0.83$ percent in March 2012). Because perennial-plant cover remained nearly constant between summer 2011 and winter 2012 (fig. 9; table 2 ), an increase in vegetation in winter 2012 could have been caused by new growth of annual plants, dominantly stickleaf (Mentzelia pumila). This increase in annuals reduced the mean basal gap length, although cumulative gap length continued to increase, reflecting a steady increase in bare sand area since summer 2010 (fig. 9). The substantial vegetation growth during the 2010 summer monsoon season was accompanied by a disproportionately greater increase in annual plants relative to perennials (fig. 9A). This increase in annual plants also was reflected in the decrease in mean basal gap lengths between winter and summer 2010 (fig. 9C) - transects intersect more plant bases after new annual plants have germinated. Basal gap length decreased in 2011 relative to 2010 as annual plants died, because annuals did not germinate extensively during the very dry summer of 2011.

Invasive Russian thistle was by far the most abundant annual plant in the study area. In the first four surveys, Russian thistle composed 100 percent (March 2010), 70 percent (August 2010), 96 percent (March 2011), and 93 percent (August 2011) of the total annual-plant cover. After the 2010 monsoon rains, total vegetation cover increased by a factor of 2.3 , whereas Russian thistle increased by a factor of nearly 15 . The abundance and rapid increase of Russian thistle during 2010 likely interfered with the capacity of the BSNE traps 
to collect eolian sediment. By winter 2011, Russian thistle had died and produced abundant wind-mobile tumbleweed that accumulated in thick piles at the upwind side of the fence enclosing the sand traps, apparently inhibiting sand movement locally until the tumbleweed was removed during monthly maintenance visits. These conditions likely affected the relation between our measurements of vegetation cover and sand mobility. Loose Russian-thistle debris (tumbleweed) was abundant enough in 2011 and 2012 to warrant including it as a separate category in measurements of ground cover; at many study sites it covered 1-3 percent or more of the ground
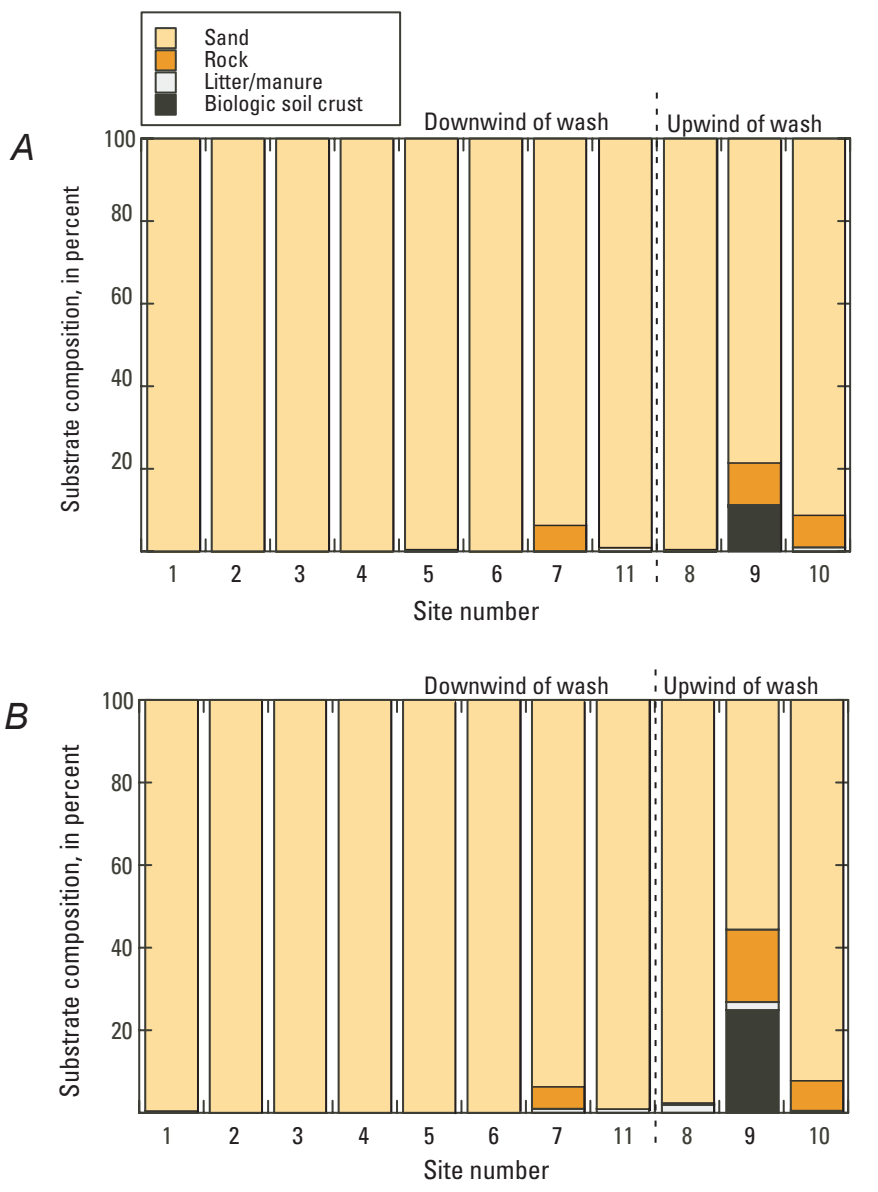

(tables 5-7). Canopy gap length corresponded well in 2010 to sand mobility as plant cover grew between March and August and as several dry years transitioned into the wetter year 2010 (fig. 9). However, even though plant cover in summer 2011 was only half that in summer 2010, measured sand transport did not increase correspondingly, possibly as an artifact of antecedent Russian thistle abundance, such that tumbleweed that grew during the 2010 monsoon rains interfered with sand collection in 2011 and even into 2012.

In contrast to the previous four surveys, the fifth survey (March 2012) showed Russian thistle composing only 32
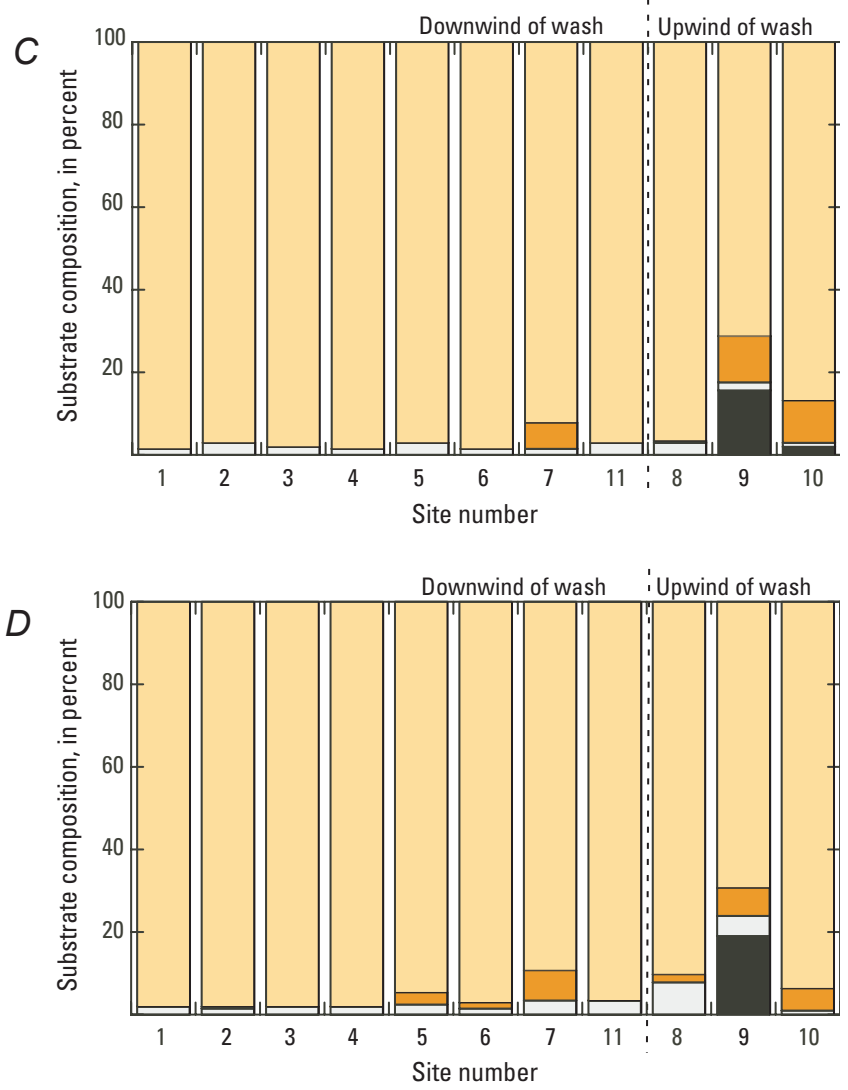

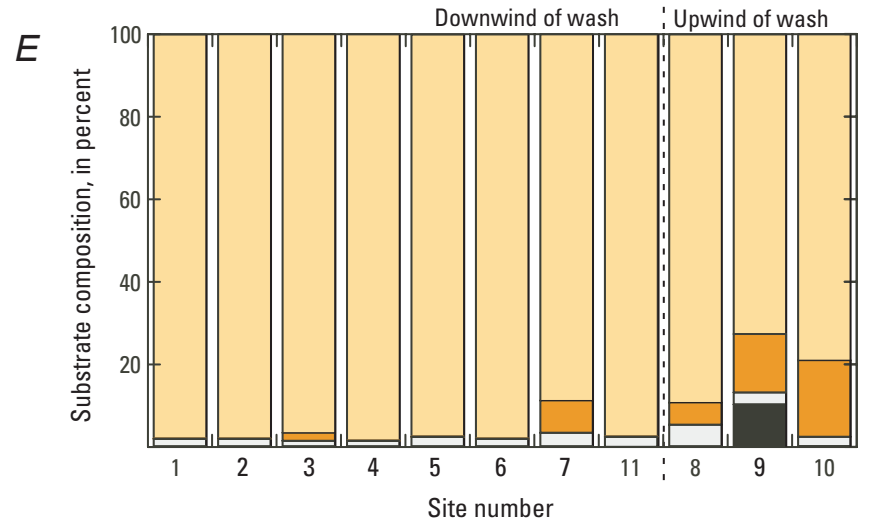

Figure 12. Substrate composition within circular plots of each pod, in $A$, March 2010; $B$, August 2010; $C$, March 2011; $D$, August 2011; and $E$, March 2012. 
Table 2. Summary of major site characteristics measured in the study area near Teesto Wash, Navajo Nation, Arizona.

[Measurement uncertainty is estimated to be 5 percent of each value given below]

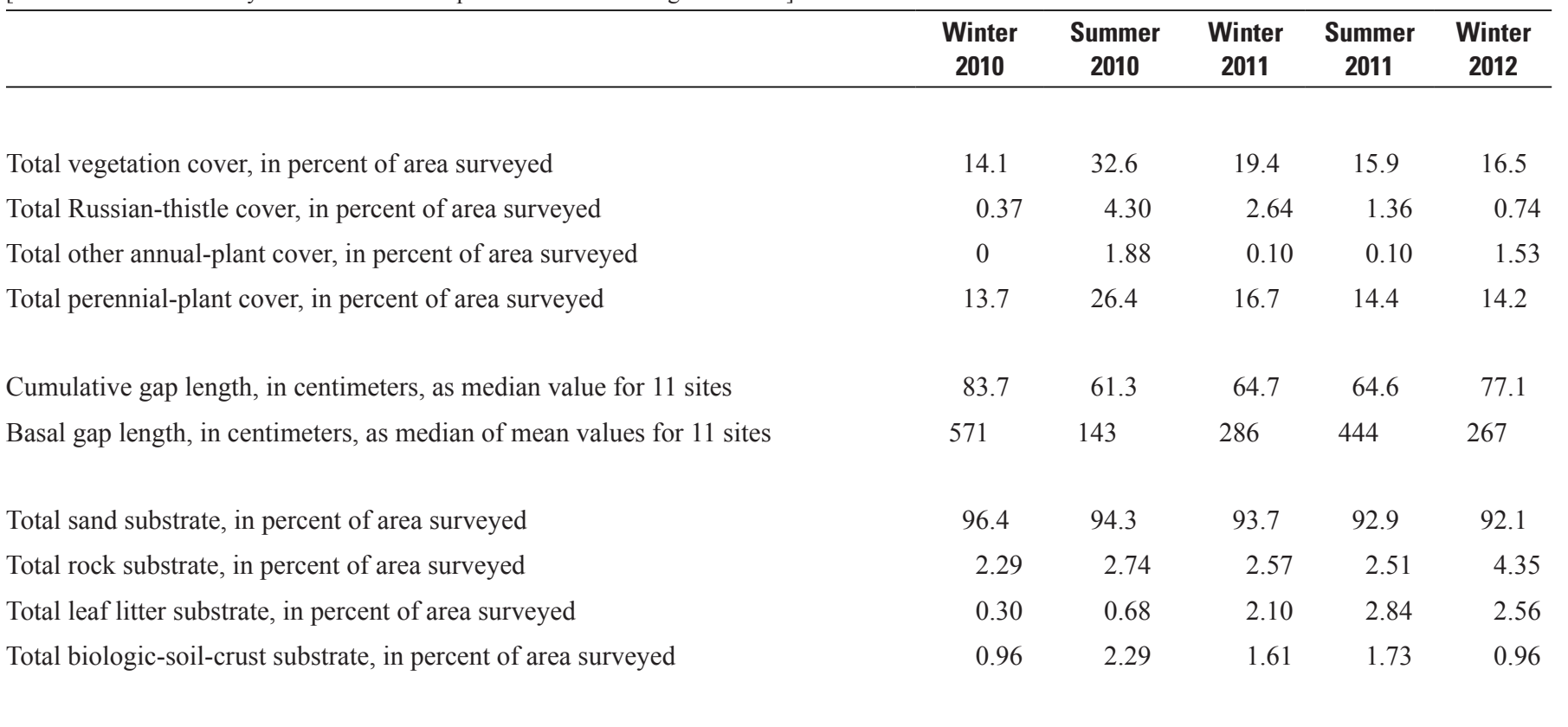

percent of annual-plant cover (fig. 9), with the rest made up of stickleaf and several other varieties of annual forbs (table 7). The winter 2012 survey was the only time during the study interval when no living Russian thistle was observed in the study area - all Russian thistle plants included in the survey (and others outside of the survey pods) were dead, and no green seedlings were observed, whereas live green seedlings of other annual plants, notably stickleaf, were abundant.

\section{Discussion}

The data presented here reflect conditions at the upwind edge of a dune field. In other, nearby areas with rapidly migrating sand dunes devoid or nearly devoid of vegetation, sand mobility and transport likely are much greater than in our study area. We have omitted such terrain from our study because rapid dune migration (more than $30 \mathrm{~m}$ during spring 2011; Redsteer and others, 2011) makes it impossible to deploy equipment in the field or to reoccupy the same sites for vegetation measurements. Instead, the present study has focused on conditions within a landscape where dunes are currently stable enough for people to live, work, and raise livestock. Relations discussed among vegetation cover and eolian sediment transport and erodibility on this Navajo Nation landscape are highly relevant also to other areas of the world with similar environmental problems (for example, Kurosaki and others, 2011; Okin and others, 2011).

Relative abundance of annual and perennial plants exerts an important control on eolian sand mobility and thus on landscape stability (Urban and others, 2009; Munson and others, 2011). Annual plants can germinate, mature, and disperse seeds with only one season of good rainfall, as occurred in the study area between March and August 2010 in response to adequate monsoon rains (tables 3, 4; figs. 9, 10). However, maintenance of and increase in perennial-plant cover requires sufficient moisture in multiple consecutive seasons, not only during the summer monsoon. Perennial plants generally have stiffer, more durable stems and roots and accumulate more leaf litter around their bases, protecting the land surface from wind erosion more efficiently than do annual plants (Belnap and others, 2009; Okin and others, 2011). Therefore, although a year with good monsoon rains and abnormally dry conditions in other seasons would cause short-term annual-plant growth, such as we measured in 2010, it would not reduce eolian sediment mobility in the long term because it would not enhance long-term growth of perennials. The disproportionate increase of such annuals as Russian thistle from a good summer monsoon season, such as in 2010 (fig. 9A), is unlikely to increase landscape stability. The windy season of the southwestern United States occurs in early spring before most annual plants have established. For this reason, and also because invasive exotic plants germinate earlier and crowd out slower-growing native plants, using water that otherwise could be available to perennials, the proliferation of Russian thistle may actually decrease landscape stability. Although both annual and perennial plants increased during the wetter summer of 2010, decreasing sand mobility well into the following year (figs. 6 , 7 ), the subsequent loss of even perennial-plant cover in a dry year, such as occurred during 2011 (fig. 9A), poses a substantial risk to landscape stability in a setting prone to wind erosion. Previous research has shown that perennial-plant cover also has decreased elsewhere on the Colorado Plateau as mean annual temperatures have risen and precipitation has decreased 
over the past several decades, contributing to increased eolian sediment transport (Munson and others, 2011).

Among the 11 study sites where vegetation and substrate assemblage were measured, some differences were apparent between the sites upwind of Teesto Wash (sites 8-10; fig. 1C) and those downwind of the wash. Study sites 9 and 10 consistently had the lowest proportions of open sand substrate, with more area than at other sites occupied by rock and, especially at site 9 , biologic soil crust (fig. 12). The greater proportion of open sand substrate at study sites downwind of the wash is consistent with observations from aerial photography of windblown sand originating from the ephemerally flowing streambed of Teesto Wash and moving downwind (figs. $1 B, 1 C$ ). We infer that eolian sand thus effectively covers rock substrate and inhibits the growth of biologic crust downwind (northeast) of the wash. The sensitive organisms that compose biologic soil crust do not thrive when constantly abraded or buried by windblown sand, and extensive biologic crust growth is more commonly associated with areas where little eolian sand supply and transport occur (Lancaster, 1994; Draut, 2011, 2012). Although study site 8 is also upwind of the wash, ground cover there differs from that at other study sites because site 8 is affected strongly by livestock activity. Study site 8 is located just north of a water cistern visited frequently by cattle and horses (figs. $11 E, 11 F$ ). This site had less overall plant diversity and less native-plant cover than did most other study sites, and instead contained abundant invasive Russian thistle and silverleaf nightshade (figs. $11 E, 11 F$; tables 3-6). In the August 2010 survey, those two nonnative plant species accounted for most of the vegetation at study site 8 , with Russian thistle and silverleaf nightshade composing 43 and 23 percent, respectively, of the total vegetation cover there (table 4). The disproportionately high abundance of those two plant types is attributed to livestock preferentially grazing on other, native plant species, and the ease with which Russian thistle and silverleaf nightshade colonize disturbed areas. Although livestock may eat Russian thistle when the plant is young and small, mature Salsola is thorny and unpalatable. Silverleaf nightshade is toxic to animals and is considered a noxious weed in many states, including Arizona, owing to its rapid spread in disturbed, sandy soils (Huisinga and others, 2006).

Most climate models project that the southwestern United States will become increasingly warm and dry during the 21 st century (for example, Seager and others, 2007a, b) and some suggest that intense storms and associated flooding may increase (Trenberth, 1998). In such a scenario, perennial streamflow would continue to decline on Navajo lands (Redsteer and others, 2010a), whereas stronger, more frequent episodic floods are possible. Because dry streambeds are sources of eolian sediment (fig. 1B), flash floods during storms could supply additional material that would be entrained by wind the following spring (cf. Muhs and Holliday, 1995; Lancaster, 1997; Clarke and Rendell, 1998; Bullard and McTainsh, 2003; Han and others, 2007). Such altered patterns of rainfall and streamflow could further increase sediment supply into the dunes downwind of dry streambeds that have become common on the Navajo Nation since the 1950s (Redsteer and others, 2010b). Increased eolian sediment transport in springtime also could destabilize vegetation that initially thrived under the previous fall monsoon rain, because windblown sand damages plants by abrasion and burial (Okin and others, 2006). We propose that a negative feedback cycle could develop whereby the summer-fall monsoon rain that promotes plant growth also supplies ephemeral washes with new sand, which damages those plants once it is mobilized by wind.

Increased eolian sand transport and dune activity in such a future climate regime would further compromise living conditions for those on the Navajo Nation, as well as elsewhere in the southwestern United States. Because many Navajo residents not only have strong traditional ties to these lands but also lack the economic means to relocate elsewhere, a future combination of climate change, greater sediment mobility, and growth of invasive plants that neither stabilize dunes nor serve a useful purpose for people or livestock would negatively impact residents in the long term.

\section{Implications for the Rocky Mountains Snowpack}

Eolian sediment transport in northeastern Arizona has consequences not only for human health and infrastructure but also for the snowpack in the Rocky Mountains of Colorado, on which millions of people depend for water supply. Satellite imagery has shown dust plumes originating repeatedly from Navajo lands in and near the study area during the time interval covered by this study (for example, fig. 13; U.S. Geological Survey, 2012). Windborne dust from the southwestern Colorado Plateau is known to settle on snow in the southern Rockies, reducing its albedo and leading to earlier spring melting (Painter and others, 2007, 2010; Colorado Dust-on-Snow Program, 2011; Phillips and Doesken, 2011).

Accelerated snowmelt poses a concern for resource managers, who anticipate that the demand for water will increase as warmer, drier conditions prompt a shift from snowfall toward rainfall and increase eolian sediment transport from the Colorado Plateau. This concern is particularly great during La Niña phases of the ENSO cycle - in La Niña years, northeastern Arizona generally sees higher wind velocities and less rainfall than during El Niño phases (Enloe and others, 2004; Phillips and Doesken, 2011), and as the data from this study suggest, less vegetation cover to stabilize sandy soils. Though dominated by very fine sand, the airborne sediment mobilized from our study area contains abundant silt and some clay-size material (fig. 14), indicating that sediment in the vicinity of the study area is certainly fine enough to be transported great distances downwind toward the Rocky Mountains.

Previous studies have indicated a link between strong winds in northeastern Arizona and dust events in the southern Rockies, with a daily average wind velocity higher than 6.7 $\mathrm{m} / \mathrm{s}$ proposed as a threshold value for dust events (Phillips and Doesken, 2011), because dust particles commonly are mobilized 
by the impact of saltating sand grains (for example, Bagnold, 1941). The high springtime sediment transport and mobility measured in our study area in 2009 and 2010 are broadly consistent with the dust-on-snow deposition monitored in the San Juan Range of the southern Rocky Mountains (fig. 1A), where dust-on-snow mass was greater in spring 2009 than in any of the previous 7 years (Skiles and others, 2011). Making more specific connections between trends in eolian sand mobility in our study area and dust deposition in the southern Rocky Mountains is challenging because within the $350 \mathrm{~km}$ between the study area and the nearest snowpack downwind where dust events are recorded is such a large source area that even with a substantial reduction in sediment mobility in the vicinity of our study area, such as after substantial plant growth in a year with adequate rainfall, wind could still supply ample sediment to the San Juan Range. A longer record from the study area and elsewhere may clarify the connections between source-area eolian events and dust deposition in the mountains downwind.

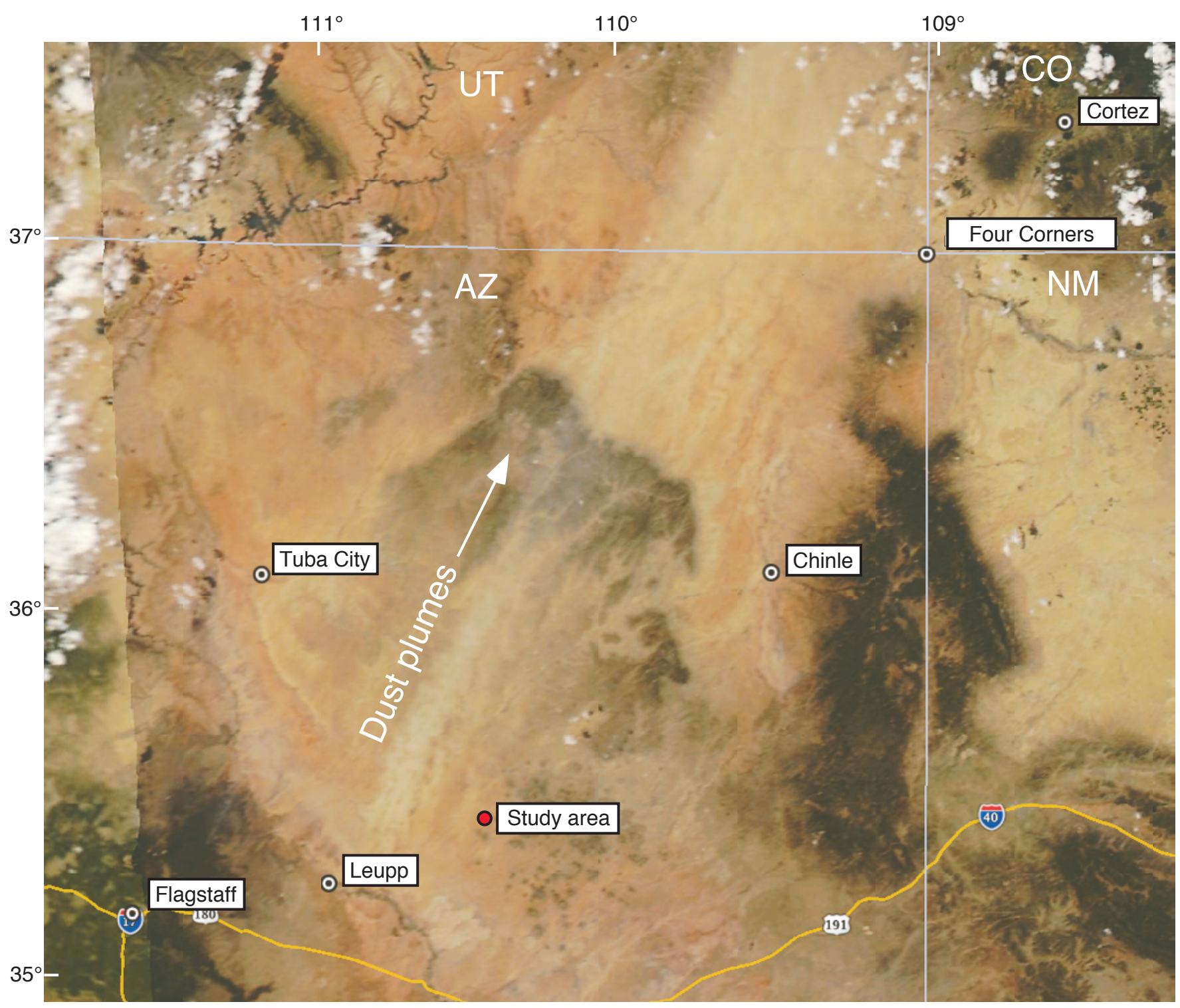

Figure 13. MODIS (Moderate Resolution Imaging Spectroradiometer) satellite image, showing eolian dust plumes that originated in northeastern Arizona, within the Navajo Nation, on the afternoon of May 29, 2011. From National Aeronautics and Space Administration, modified and posted online by the U.S. Geological Survey (2012). 

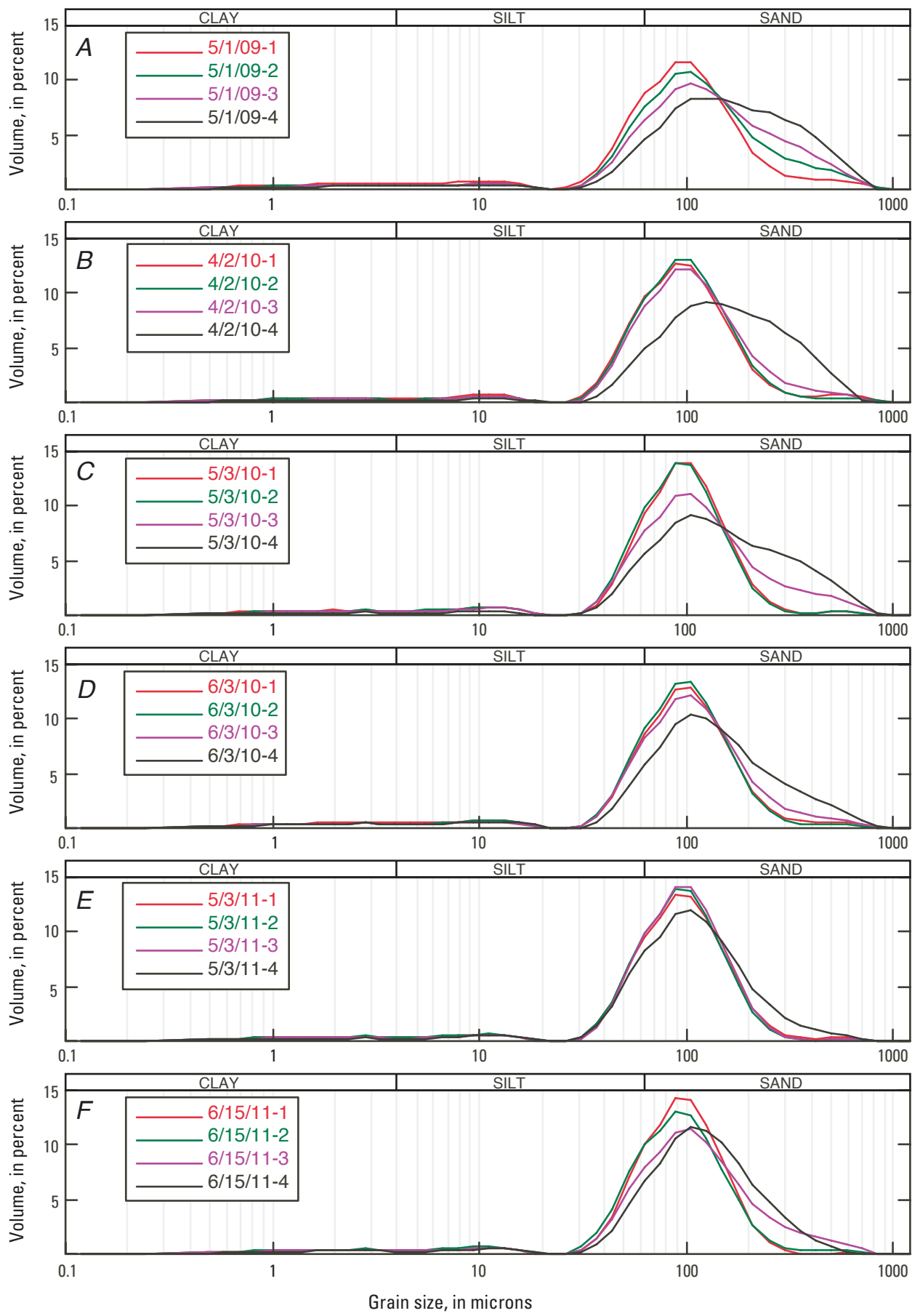

Figure 14. Particle-size data for 24 selected samples collected in Big Spring Number Eight (BSNE) sediment traps within the study area (fig. 1). All samples were obtained during spring, when wind speed is typically highest in this region. Samples were collected on $A$, May 1, 2009; $B$, April 2, 2010; $C$, May 3, 2010; D, June 3, 2010; $E$, May 3, 2011; and $F$, June 15, 2011. Numbers 1-4 after sample date indicate position of BSNE trap from which sample was collected, where 1 is uppermost and 4 is lowermost.

\section{Conclusions}

On the Navajo Nation, decreasing perennial streamflow and warming, drying trends have led to eolian sediment mobilization that affects air quality, housing, and transportation and potentially reduces the albedo of the Rocky Mountains snowpack downwind. Initial results of an intended long-term monitoring program in a $0.2-\mathrm{km}^{2}$ study area near Teesto Wash on the southern Navajo Nation indicate that sand mobility decreased substantially as one year (2010) with near-normal monsoon rainfall somewhat abated a decade-long drought, temporarily doubling vegetation cover. Perennial plants that grew during the same year with adequate monsoon rainfall 
died off rapidly during a subsequent dry year (2011). The proportion of bare, open sand area increased steadily after the short-term vegetation growth of summer 2010 began to die. Measurements in the study area have shown substantially greater vegetation cover during a year when the ENSO cycle was in the El Niño phase than during several years in the La Niña phase. Isolated seasonal increases in rainfall will not improve landscape stability in the long term because a sustained increase in perennial-plant cover, more effective than annual plants at stabilizing sand against wind erosion, requires multiple consecutive seasons of adequate rain. Climate projections suggest that warmer, drier conditions during the coming decades could potentially enhance eolian sediment supply after flash floods in otherwise dry, ephemeral washes. Such conditions could combine to decrease vegetation cover and increase eolian sediment transport and dune activity, worsening the present challenges to people living in this region.

\section{Acknowledgments}

This study was supported by the U.S. Geological Survey. Research was conducted with permission from the Navajo Nation Department of Minerals, the Navajo Nation Historic Preservation Office, and the Navajo Nation Water Management Branch. We also are indebted to the Biggambler family for providing room in their grazing land for this study. Leanna Begay and Arnold Clifford provided information on plant species within the Navajo Nation. Particle-size analyses were performed by Harland Goldstein of the USGS Geology and Environmental Change Science Center. The cover photograph was taken by Jon Mason of the USGS Flagstaff Science Center. Finally, we thank Daniel Muhs (USGS) and Melissa McMaster (National Park Service) for their constructive reviews of the manuscript, and George Havach (USGS) for his editorial comments.

\section{References Cited}

Anderson, R.S., and Hallet, B., 1986, Sediment transport by wind - toward a general model: Geological Society of America Bulletin, v. 97, p. 523-535.

Bagnold, R.A., 1941, The physics of blown sand and desert dunes: London, Methuen and Co., Ltd., 265 p.

Bailey, G., and Bailey, R.G., 1986, A history of the Navajoes - the reservation years ( $2 \mathrm{~d}$ ed.): Santa Fe, N. Mex., School of American Research Press, 360 p.

Belnap, J., Kaltenecker, J.H., Rosentreter, R., Williams, J., Leonard, S., and Eldridge, D., 2001, Biological soil crustsecology and management: Denver, Colo., U.S. Department of the Interior Technical Reference 1730-2, 110 p.
Belnap, J., and Lange, O.L., eds., 2003, Biological soil crusts - structure, function, and management, (Ecological Studies series, No. 150): Berlin, Springer-Verlag, 503 p.

Belnap, J., Reynolds, R.L., Reheis, M.C., Phillips, S.L., Urban, F.E., and Goldstein, H.L., 2009, Sediment losses and gains across a gradient of livestock grazing and plant invasion in a cool, semi-arid grassland, Colorado Plateau, USA: Aeolian Research, v. 1, p. 27-43.

Buckley, R., 1987, The effect of sparse vegetation on the transport of dune sand by wind: Nature, v. 325, p. 426-428.

Bullard, J.E., and Livingstone, I., 2002, Interactions between aeolian and fluvial systems in dryland environments: Area, v. 34 , no. 1 , p. $8-16$.

Bullard, J.E., and McTainsh, G.H., 2003, Aeolian-fluvial interactions in dryland environments; examples, concepts, and Australia case study: Progress in Physical Geography, v. 27 , p. $471-501$.

Clarke, M.L., and Rendell, H.M., 1998, Climate change impacts on sand supply and the formation of desert sand dunes in the south-west USA: Journal of Arid Environments, v. 39, p. 517-531.

Colorado Dust-on-Snow Program, 2011, Center for Snow and Avalanche Studies, Silverton, Colo., http://www.snowstudies.org/codos1.html, accessed June 20, 2012.

Cornelis, W.M., 2006, Hydroclimatology of wind erosion in arid and semi-arid environments, in D'Odorico, P., and Porporato, A., eds., Dryland ecohydrology: Dordrecht, Springer, p. 141-159.

Dominguez, F., Cañon, J., and Valdes, J., 2010, IPCC-AR4 climate simulations for the southwestern U.S.- the importance of future ENSO projections: Climatic Change, v. 99, p. 499-514.

Dong, Z., Liu, X., Wang, H., and Wang, X., 2003, Aeolian sand transport - a wind tunnel model: Sedimentary Geology, v. 161, p. 71-83.

Draut, A.E., and Rubin, D.M., 2006, Measurements of wind, aeolian sand transport, and precipitation in the Colorado River corridor, Grand Canyon, Arizona - January 2005 to January 2006: U.S. Geological Survey Open-File Report 2006-1188, 88 p., http://pubs.usgs.gov/of/2006/1188/

Draut, A.E., and Gillette, E.R., 2010, Vegetation and substrate on aeolian landscapes in the Colorado River corridor, Cataract Canyon, Utah: U.S. Geological Survey Open-File Report 2010-1273, 61 p., http://pubs.usgs.gov/ of/2010/1273/ 
Draut, A.E., 2011, Vegetation and substrate properties of aeolian dune fields in the Colorado River corridor, Grand Canyon, Arizona, U.S. Geological Survey Open-File Report 2011-1195, 16 p., http://pubs.usgs.gov/of/2011/1195/

Draut, A.E., 2012, Effects of river regulation on aeolian landscapes, Colorado River, southwestern U.S.A.: Journal of Geophysical Research-Earth Surface, v. 117, F2, doi:10.1029/2011JF002329.

Enloe, J., O'Brien, J.J., and Smith, S.R., 2004, ENSO impacts on peak wind gusts in the United States: Journal of Climate, v. 17, p. $1728-1737$.

Fryrear, D.W., 1986, A field dust sampler: Journal of Soil and Water Conservation, v. 41, p. 117-119.

Goossens, D., Offer, Z., and London, G., 2000, Wind tunnel and field calibration of five aeolian sand traps: Geomorphology, v. 35, p. 233-252.

Hack, J.T., 1941, Dunes of the western Navajo country: Geographical Review, v. 31, p. 240-263.

Han, G., Zhang, G., and Dong, Y., 2007, A model for the active origin and development of source-bordering dunefields on a semiarid fluvial plan - a case study from the Xiliaohe Plain, Northeast China: Geomorphology, v. 86, p. 512-524.

Herrick, J.E., Van Zee, J.W., Havstad, K.M., Burkett, L.M., and Whitford, W.G., 2005, Monitoring manual for grassland, shrubland, and savanna ecosystems, Las Cruces, New Mexico: U.S. Department of Agriculture and University of Arizona Press, 36 p.

Jewell, P.W., and Nicoll, K., 2011, Wind regimes and aeolian transport in the Great Basin, U.S.A.: Geomorphology, v. 129, p. 1-13.

Kurosaki, Y., Shinoda, M., and Mikami, M., 2011, What caused a recent increase in dust outbreaks over East Asia?: Geophysical Research Letters, v. 38, L11702.

Lancaster, N., 1994, Controls on aeolian activity—some new perspectives from the Kelso Dunes, Mojave Desert, California: Journal of Arid Environments, v. 27, p. 113-125.

Lancaster, N., 1997, Response of eolian geomorphic systems to minor climate change- - examples from the southern California deserts: Geomorphology, v. 19, p. 333-347.

Muhs, D.R., and Holliday, V.T., 1995, Evidence of active dune sand on the Great Plains in the $19^{\text {th }}$ century from accounts of early explorers: Quaternary Research, v. 43, p. 198-208.

Muhs, D.R., Reynolds, R.L., Been, J., and Skipp, G., 2003, Eolian sand transport pathways in the southwestern United States: importance of the Colorado River and local sources: Quaternary International, v. 104, p. 3-18.
Muhs, D.R., and Been, J.M., 2004, Reactivation of stabilized sand dunes on the Colorado Plateau: http://geochange. er.usgs.gov/sw/impacts/geology/sand/, accessed June 20, 2012.

Munson, S.M., Belnap, J., and Okin, G.S., 2011, Responses of wind erosion to climate-induced vegetation changes on the Colorado Plateau: National Academy of Sciences Proceedings, v. 108, p. 3854-3859.

National Climatic Data Center, 2011, State of the Climate National Overview: National Oceanic and Atmospheric Administration, http://www.ncdc.noaa.gov, accessed June 20, 2012.

Norris, T., Vines, P.L., and Hoeffel, E.M., 2010, The American Indian and Alaska Native population, 2010: U.S. Census Bureau, 21 p., http://www.census.gov, accessed June 20, 2012.

O'Brien, M.P., and Rindlaub, B.D., 1936, The transport of sand by wind: Civil Engineering, v. 6, p. 254-263.

Okin, G.S., Gillette, D.A., and Herrick, J.E., 2006, Multi-scale controls on and consequences of aeolian processes in landscape change in arid and semi-arid environments: Journal of Arid Environments, v. 65, p. 253-275.

Okin, G.S., Bullard, J.E., Reynolds, R.L., Ballantine, J.-A.C., Schepanski, K., Todd, M.C., Belnap, J., Baddock, M.C., Gill, T.E., and Miller, M.E., 2011, Dust-small-scale processes with global consequences: Eos (American Geophysical Union Transactions), v. 92, no. 29, p. 241-242.

Painter, T.H., Barrett, A.P., Landry, C.C., Neff, J.C., Cassidy, M.P., Lawrence, C.R., McBride, K.E., and Farmer, G.L., 2007, Impact of disturbed desert soils on duration of mountain snow cover: Geophysical Research Letters, v. 34, L12502.

Painter, T.H., Deems, J.S., Belnap, J., Hamlet, A.F., Landry, C.C., and Udall, B., 2010, Response of Colorado River runoff to dust radiative forcing in snow: National Academy of Sciences Proceedings, v. 107, p. 17125-17130.

Phillips, M., and Doesken, N., 2011, Continental wind patterns associated with Colorado alpine dust deposition - an application of the BLM/USFS RAWS network: Journal of Service Climatology, v. 5, p. 1-11.

Redsteer, M.H., Kelley, K.B., Francis, H., and Block, D., 2010a, Disaster risk assessment case study — recent drought on the Navajo Nation, southwestern United States; contributing case study to the 2011 United Nations Global Assessment Report on Disaster Risk Reduction, annexes and papers: http://www.preventionweb.net/english/hyogo/ gar/2011/en/home/annexes.html, accessed June 20, 2012. 
Redsteer, M.H., Bogle, R., Vogel, J., Block, D., and Middleton, B., 2010b, The history and growth of a recent dune field at Grand Falls, Navajo Nation, NE Arizona [abs.]: Geological Society of America Abstracts with Programs, v. 170 , no. 5 , p. 416 .

Redsteer, M.H., Bogle, R.C., and Vogel, J.M., 2011, Monitoring and analysis of sand dune movement and growth on the Navajo Nation, southwestern United States: U.S. Geological Survey Fact Sheet 2011-3085, http://pubs.usgs.gov/ fs $/ 2011 / 3085 /$.

Seager, R., 2007a, The turn of the century North American drought - global context, dynamics, and past analogs: Journal of Climate, v. 20, p. 5527-5552.

Seager, R., Ting, M., Held, I., Kushnir, Y., Lu, J., Vecchi, G., Huang, H.-P., Hamik, N., Leetmaa, A., Lau, N.-C., Li, C., Velez, J., and Naik, N., 2007b, Model projections of an imminent transition to a more arid climate in southwestern North America: Science, v. 316, p. 1181-1184.

Skiles, M., Painter, T.H., Deems, J.S., and Barrett, A.P., 2011, Interannual variability in dust deposition, radiative forcing, and snowmelt rates in the Colorado River basin: American Geophysical Union, Fall Meeting, San Francisco, Calif., December 5-9, 2011, C41F-05.

Solomon, S., Qin, D., Manning, M., Chen, Z., Marquis, M., Averyt, K.B., Tignor, M., and Miller, H.L., eds., 2007, Climate change 2007-the physical science basis: Contribution of Working Group I to the Fourth Assessment Report of the Intergovernmental Report on Climate Change: Cambridge, U.K., Cambridge University Press, 996 p.

Sterk, G., and Raats, P.A.C., 1996, Comparison of models describing the vertical distribution of wind-eroded sediment: Soil Science Society of America Journal, v. 60, p. 1914-1919.

Trenberth, K., 1998, Atmospheric moisture residence times and cycling -implications for rainfall rates and climate change: Climatic Change, v. 39, p. 667-694.

U.S. Census Bureau, 2000, Table DP-1 - profile of general demographic characteristics, Navajo Nation reservation and off-reservation trust land, AZ-NM-UT: http://www.census. gov/, accessed June 20, 2012.

U.S. Geological Survey, 2012, Dust monitoring and dust events, Southwest Geographic Science Team: http://sgst. wr.usgs.gov/dust_monitoring/dust-events/, last accessed June 20, 2012.

Urban, F.E., Reynolds, R.L., and Fulton, R., 2009, The dynamic interaction of climate, vegetation, and dust emission, Mojave Desert, USA, in Fernandez-Bernal, A., and De la Rosa, M.A., eds., Arid environments and wind erosion: Hauppauge, N.Y., Nova Science, p. 243-267.
Weiss, J.L., Castro, C.L., and Overpeck, J.T., 2009, Distinguishing pronounced droughts in the southwestern United States - seasonality and effects of warmer temperatures: Journal of Climate, v. 22, p. 5918-5932.

Westerling, A.L., Hidalgo, H.G., Cayan, D.R., and Swetnam, T.W., 2006, Warming and earlier spring increase western U.S. forest wildfire activity: Science, v. 313, p. 940-943.

Zobeck, T.M., Sterk, G., Funk, R., Rajot, J.L., Stout, J.E., and Van Pelt, R.S., 2003, Measurement and data analysis methods for field-scale wind erosion studies and model validation: Earth Surface Processes and Landforms, v. 28, p. $1163-1188$. 
This page left intentionally blank. 


\section{Appendix 1. Supplementary Information}


Table 3. Vegetation cover and substrate measured in March 2010 in the study area near Teesto Wash, Navajo Nation, Arizona.

[Coverage is given in terms of area and percentage within five circles of radius $3 \mathrm{~m}$, as shown in figure 3]

Site 1

\begin{tabular}{lcc}
\hline \multicolumn{1}{c}{ Vegetation } & $\begin{array}{c}\text { Area, in square } \\
\text { meters }\end{array}$ & Percentage \\
\hline Unidentified perennial grass & 5.51 & 3.90 \\
Mojave indigobush (Psorothamnus arborescens) & 3.25 & 2.30 \\
Snakeweed (Gutierrezia sarothrae) & 2.32 & 1.64 \\
Rabbitbrush (Ericameria nauseosus) & 0.71 & 0.50 \\
Unidentified aster (Asteraceae family) & 0.28 & 0.20 \\
Saltbush (Atriplex canescens) & 0.14 & 0.10 \\
Unidentified shrub, dead & 0.14 & 0.10 \\
Narrowleaf yucca (Yucca angustissima) & 0.06 & 0.04 \\
Russian thistle (Salsola sp.) & 0.03 & 0.02 \\
\hline Total vegetation cover & 12.4 & 8.8 \\
\hline & Area, in square & Percentage \\
\hline Sand & meters & 100 \\
Rock & 141 & 0 \\
Leaf litter & 0 & 0 \\
Biologic soil crust & 0 & 0 \\
\hline Total gap length, in percent & 0 & 1,000 \\
\hline Mean basal gap length, in centimeters & & 01.4 \\
\hline
\end{tabular}


Table 3. Vegetation cover and substrate measured in March 2010 in the study area near Teesto Wash, Navajo Nation, Arizona.-Continued

Site 2

\begin{tabular}{lcc}
\hline \multicolumn{1}{c}{ Vegetation } & $\begin{array}{c}\text { Area, in square } \\
\text { meters }\end{array}$ & Percentage \\
\hline Mojave indigobush (Psorothamnus arborescens) & 11.3 & 8.00 \\
Snakeweed (Gutierrezia sarothrae) & 4.24 & 3.00 \\
Unidentified perennial grass & 2.54 & 1.80 \\
Unidentified shrub, dead & 1.58 & 1.12 \\
Rabbitbrush (Ericameria nauseosus) & 1.56 & 1.10 \\
Basin wildrye (Leymus cinereus) & 0.14 & 0.10 \\
Russian thistle (Salsola sp.) & 0.14 & 0.10 \\
\hline Total vegetation cover & 21.5 & 15.2 \\
\hline \multicolumn{1}{c}{ Substrate } & Area, in square & Percentage \\
\hline Sand & meters & 99.9 \\
Rock & 141 & 0.06 \\
Leaf litter & 0.08 & 0 \\
Biologic soil crust & 0 & 0 \\
\hline Total gap length, in percent & 0 & 89.5 \\
\hline Mean basal gap length, in centimeters & & 1,000
\end{tabular}

Site 3

\begin{tabular}{lcc}
\hline \multicolumn{1}{c}{ Vegetation } & $\begin{array}{c}\text { Area, in square } \\
\text { meters }\end{array}$ & Percentage \\
\hline Mojave indigobush (Psorothamnus arborescens) & 11.5 & 8.10 \\
Rabbitbrush (Ericameria nauseosus) & 2.83 & 2.00 \\
Unidentified perennial grass & 2.77 & 1.96 \\
Unidentified shrub, dead & 1.19 & 0.84 \\
Snakeweed (Gutierrezia sarothrae) & 0.96 & 0.68 \\
Russian thistle (Salsola sp.) & 0.45 & 0.32 \\
\hline Total vegetation cover & 19.7 & 13.9 \\
\hline \multicolumn{1}{c}{ Substrate } & Area, in square & Percentage \\
\hline Sand & meters & 100 \\
Rock & 141 & 0 \\
Leaf litter & 0 & 0 \\
Biologic soil crust & 0 & 0 \\
\hline Total gap length, in percent & 0 & 75.2 \\
\hline Mean basal gap length, in centimeters & & 222
\end{tabular}


Table 3. Vegetation cover and substrate measured in March 2010 in the study area near Teesto Wash, Navajo Nation, Arizona.-Continued

Site 4

\begin{tabular}{lcc}
\hline \multicolumn{1}{c}{ Vegetation } & $\begin{array}{c}\text { Area, in square } \\
\text { meters }\end{array}$ & Percentage \\
\hline Mojave indigobush (Psorothamnus arborescens) & 16.1 & 11.4 \\
Snakeweed (Gutierrezia sarothrae) & 1.75 & 1.24 \\
Russian thistle (Salsola sp.) & 1.05 & 0.74 \\
Unidentified perennial grass & 0.62 & 0.44 \\
Rabbitbrush (Ericameria nauseosus) & 0.51 & 0.36 \\
Unidentified shrub, dead & 0.14 & 0.10 \\
\hline Total vegetation cover & 20.2 & 14.3 \\
\hline \multicolumn{1}{c}{ Substrate } & Area, in square & Percentage \\
\hline Sand & meters & 100 \\
Rock & 141 & 0 \\
Leaf litter & 0 & 0 \\
Biologic soil crust & 0 & 0 \\
\hline Total gap length, in percent & 0 & 81.4 \\
\hline Mean basal gap length, in centimeters & & 500
\end{tabular}

Site 5

\begin{tabular}{lcc}
\hline \multicolumn{1}{c}{ Vegetation } & $\begin{array}{c}\text { Area, in square } \\
\text { meters }\end{array}$ & Percentage \\
\hline Rabbitbrush (Ericameria nauseosus) & 11.3 & 8.00 \\
Mojave indigobush (Psorothamnus arborescens) & 5.94 & 4.20 \\
Snakeweed (Gutierrezia sarothrae) & 3.96 & 2.80 \\
Unidentified perennial grass & 0.31 & 0.22 \\
Unidentified shrub, dead & 0.14 & 0.10 \\
Russian thistle (Salsola sp.) & 0.08 & 0.06 \\
\hline Total vegetation cover & 21.7 & 15.4 \\
\hline \multicolumn{1}{c}{ Substrate } & Area, in square & Percentage \\
meters & 99.3 \\
Sand & 140 & 0.72 \\
Rock & 1.02 & 0 \\
Leaf litter & 0 & 0 \\
\hline Biologic soil crust & 0 & 83.8 \\
\hline Total gap length, in percent & & 500 \\
\hline Mean basal gap length, in centimeters & & \\
\end{tabular}


Table 3. Vegetation cover and substrate measured in March 2010 in the study area near Teesto Wash, Navajo Nation, Arizona.-Continued

Site 6

\begin{tabular}{lcc}
\hline \multicolumn{1}{c}{ Vegetation } & $\begin{array}{c}\text { Area, in square } \\
\text { meters }\end{array}$ & Percentage \\
\hline Mojave indigobush (Psorothamnus arborescens) & 9.19 & 6.50 \\
Rabbitbrush (Ericameria nauseosus) & 4.24 & 3.00 \\
Snakeweed (Gutierrezia sarothrae) & 2.21 & 1.56 \\
Unidentified perennial grass & 1.13 & 0.80 \\
Unidentified shrub, dead & 0.85 & 0.60 \\
Russian thistle (Salsola sp.) & 0.74 & 0.52 \\
\hline Total vegetation cover & 18.4 & 13.0 \\
\hline \multicolumn{1}{c}{ Substrate } & Area, in square & Percentage \\
\hline Sand & 141 & 100 \\
Rock & 0.03 & 0.02 \\
Leaf litter & 0 & 0 \\
Biologic soil crust & 0 & 0 \\
\hline Total gap length, in percent & & 83.7 \\
\hline Mean basal gap length, in centimeters & & 500
\end{tabular}

Site 7

\begin{tabular}{lcc}
\hline \multicolumn{1}{c}{ Vegetation } & $\begin{array}{c}\text { Area, in square } \\
\text { meters }\end{array}$ & Percentage \\
\hline Rabbitbrush (Ericameria nauseosus) & 23.9 & 16.9 \\
Mojave indigobush (Psorothamnus arborescens) & 10.0 & 7.10 \\
Unidentified perennial grass & 1.19 & 0.84 \\
Russian thistle (Salsola sp.) & 0.28 & 0.20 \\
Snakeweed (Gutierrezia sarothrae) & 0.25 & 0.18 \\
Saltbush (Atriplex canescens) & 0.20 & 0.14 \\
\hline Total vegetation cover & 35.9 & 25.4 \\
\hline \multicolumn{1}{c}{ Substrate } & Area, in square & Percentage \\
\hline meters & 133 & 93.9 \\
Rock & 8.65 & 6.12 \\
Leaf litter & 0 & 0 \\
Biologic soil crust & 0 & 0 \\
\hline Total gap length, in percent & & 81.9 \\
\hline Mean basal gap length, in centimeters & & 1,000
\end{tabular}


Table 3. Vegetation cover and substrate measured in March 2010 in the study area near Teesto Wash, Navajo Nation, Arizona.-Continued

Site 8

\begin{tabular}{lcc}
\hline \multicolumn{1}{c}{ Vegetation } & $\begin{array}{c}\text { Area, in square } \\
\text { meters }\end{array}$ & Percentage \\
\hline Unidentified perennial grass & 3.39 & 2.40 \\
Russian thistle (Salsola sp.) & 2.69 & 1.90 \\
Snakeweed (Gutierrezia sarothrae) & 1.72 & 1.22 \\
\hline Total vegetation cover $\quad$ Substrate & 7.80 & 5.52 \\
\hline \multicolumn{2}{c}{ Area, in square } & Percentage \\
\hline Sand & 141 & 99.4 \\
Rock & 0.11 & 0.08 \\
Leaf litter & 0.71 & 0.50 \\
Biologic soil crust & 0 & 0 \\
\hline Total gap length, in percent & & 95.8 \\
\hline Mean basal gap length, in centimeters & & 2,000
\end{tabular}

Site 9

\begin{tabular}{lcc}
\hline \multicolumn{1}{c}{ Vegetation } & $\begin{array}{c}\text { Area, in square } \\
\text { meters }\end{array}$ & Percentage \\
\hline Mojave indigobush (Psorothamnus arborescens) & 12.2 & 8.60 \\
Undifferentiated shrubs, live & 6.22 & 4.40 \\
Unidentified shrubs, dead & 3.39 & 2.40 \\
Rabbitbrush (Ericameria nauseosus) & 0.42 & 0.30 \\
Unidentified perennial grass & 0.06 & 0.04 \\
Snakeweed (Gutierrezia sarothrae) & 0.03 & 0.02 \\
\hline Total vegetation cover & 22.3 & 15.8 \\
\hline \multicolumn{1}{c}{ Substrate } & Area, in square & Percentage \\
\hline Sand & meters & 78.4 \\
Rock & 111 & 10.2 \\
Leaf litter & 14.4 & 0.80 \\
Biologic soil crust & 1.13 & 10.6 \\
\hline Total gap length, in percent & 15.0 & 69.1 \\
\hline Mean basal gap length, in centimeters & & 571
\end{tabular}


Table 3. Vegetation cover and substrate measured in March 2010 in the study area near Teesto Wash, Navajo Nation, Arizona.-Continued

Site 10

\begin{tabular}{|c|c|c|}
\hline Vegetation & $\begin{array}{c}\text { Area, in square } \\
\text { meters }\end{array}$ & Percentage \\
\hline Rabbitbrush (Ericameria nauseosus) & 7.92 & 5.60 \\
\hline Mojave indigobush (Psorothamnus arborescens) & 4.67 & 3.30 \\
\hline Unidentified shrubs, dead & 0.85 & 0.60 \\
\hline Snakeweed (Gutierrezia sarothrae) & 0.28 & 0.20 \\
\hline Unidentified perennial grass & 0.11 & 0.08 \\
\hline Total vegetation cover & 13.8 & 9.78 \\
\hline Substrate & $\begin{array}{c}\text { Area, in square } \\
\text { meters }\end{array}$ & Percentage \\
\hline Sand & 129 & 91.1 \\
\hline Rock & 11.3 & 8.00 \\
\hline Leaf litter & 1.33 & 0.94 \\
\hline Biologic soil crust & 0 & 0 \\
\hline Total gap length, in percent & & 88.8 \\
\hline Mean basal gap length, in centimeters & & 489 \\
\hline
\end{tabular}

Site 11

\begin{tabular}{lcc}
\hline \multicolumn{1}{c}{ Vegetation } & $\begin{array}{c}\text { Area, in square } \\
\text { meters }\end{array}$ & Percentage \\
\hline Snakeweed (Gutierrezia sarothrae) & 0.57 & 0.40 \\
Unidentified perennial grass & 0.08 & 0.06 \\
Mojave indigobush (Psorothamnus arborescens) & 3.68 & 2.60 \\
Unidentified shrubs, dead & 1.44 & 1.02 \\
Undifferentiated shrubs, live & 19.8 & 14.0 \\
Russian thistle (Salsola sp.) & 0.25 & 0.18 \\
\hline Total vegetation cover & 25.8 & 18.3 \\
\hline \multicolumn{1}{c}{ Substrate } & Area, in square & Percentage \\
\hline Sand & meters & 98.9 \\
Rock & 140 & 0 \\
Leaf litter & 0 & 1.10 \\
Biologic soil crust & 1.56 & 0 \\
\hline Total gap length, in percent & 0 & 75.3 \\
\hline Mean basal gap length, in centimeters & & 571 \\
\hline
\end{tabular}


Table 4. Vegetation cover and substrate measured in August 2010 in the study area near Teesto Wash, Navajo Nation, Arizona.

[Coverage is given in terms of area and percentage within five circles of radius $3 \mathrm{~m}$, as shown in figure 3]

Site 1

\begin{tabular}{|c|c|c|}
\hline Vegetation & $\begin{array}{c}\text { Area, in square } \\
\text { meters }\end{array}$ & Percentage \\
\hline Alkali sacoton (Sporobolus airoides) & 11.5 & 8.10 \\
\hline Mojave indigobush (Psorothamnus arborescens) & 3.78 & 2.68 \\
\hline Russian thistle (Salsola sp.) & 3.78 & 2.68 \\
\hline Plains spring parsley (Cymopterus acaulis) & 1.48 & 1.05 \\
\hline Indian ricegrass (Oryzopsis hymenoides) & 1.45 & 1.03 \\
\hline Unidentified shrub, dead & 1.27 & 0.90 \\
\hline Rabbitbrush (Ericameria nauseosus) & 1.20 & 0.85 \\
\hline Sandhill muhly (Muhlenbergia pungens) & 0.85 & 0.60 \\
\hline Stickleaf (Mentzelia pumila) & 0.85 & 0.60 \\
\hline Purple three-awn (Aristida purpurea) & 0.71 & 0.50 \\
\hline Narrowleaf yucca (Yucca angustissima) & 0.57 & 0.40 \\
\hline Dicoria (Dicoria canescens) & 0.35 & 0.25 \\
\hline Doveweed (Croton texensis) & 0.18 & 0.13 \\
\hline Unidentified annual forb & 0.14 & 0.10 \\
\hline Galleta grass (Pleuraphis jamesii) & 0.14 & 0.10 \\
\hline Greene's rabbitbrush (Chrysothamnus greenei) & 0.14 & 0.10 \\
\hline Snakeweed (Gutierrezia sarothrae) & 0.07 & 0.05 \\
\hline Giant dropseed (Sporobolus giganteus) & 0.07 & 0.05 \\
\hline Sand verbena (Abronia fragrans) & 0.07 & 0.05 \\
\hline Milkweed (Asclepias sp.) & 0.07 & 0.05 \\
\hline Total vegetation cover & 28.6 & 20.3 \\
\hline Substrate & $\begin{array}{c}\text { Area, in square } \\
\text { meters }\end{array}$ & Percentage \\
\hline Sand & 141 & 100 \\
\hline Rock & 0 & 0 \\
\hline Leaf litter & 0.60 & 0.43 \\
\hline Biologic soil crust & 0 & 0 \\
\hline \multicolumn{2}{|l|}{ Total gap length, in percent } & 57.3 \\
\hline Mean basal gap length, in centimeters & & 87 \\
\hline
\end{tabular}


Table 4. Vegetation cover and substrate measured in August 2010 in the study area near Teesto Wash, Navajo Nation, Arizona.-Continued

Site 2

\begin{tabular}{|c|c|c|}
\hline Vegetation & $\begin{array}{c}\text { Area, in square } \\
\text { meters }\end{array}$ & Percentage \\
\hline Mojave indigobush (Psorothamnus arborescens) & 6.79 & 4.80 \\
\hline Unidentified shrub, dead & 3.78 & 2.68 \\
\hline Russian thistle (Salsola sp.) & 3.25 & 2.30 \\
\hline Stickleaf (Mentzelia pumila) & 2.69 & 1.90 \\
\hline Rabbitbrush (Ericameria nauseosus) & 1.84 & 1.30 \\
\hline Indian ricegrass (Oryzopsis hymenoides) & 1.41 & 1.00 \\
\hline Plains spring parsley (Cymopterus acaulis) & 1.34 & 0.95 \\
\hline Sandhill muhly (Muhlenbergia pungens) & 1.17 & 0.83 \\
\hline Alkali sacoton (Sporobolus airoides) & 0.99 & 0.70 \\
\hline Galleta grass (Pleuraphis jamesii) & 0.57 & 0.40 \\
\hline Doveweed (Croton texensis) & 0.49 & 0.35 \\
\hline Snakeweed (Gutierrezia sarothrae) & 0.46 & 0.33 \\
\hline Dicoria (Dicoria canescens) & 0.42 & 0.30 \\
\hline Bindweed heliotrope (Heliotropium convolvulaceum) & 0.21 & 0.15 \\
\hline Unidentified annual forb & 0.14 & 0.10 \\
\hline Wire lettuce (Stephanomeria pauciflora) & 0.14 & 0.10 \\
\hline Total vegetation cover & 25.7 & 18.2 \\
\hline Substrate & $\begin{array}{l}\text { Area, in square } \\
\text { meters }\end{array}$ & Percentage \\
\hline Sand & 141 & 99.9 \\
\hline Rock & 0 & 0 \\
\hline Leaf litter & 0.18 & 0.13 \\
\hline Biologic soil crust & 0 & 0 \\
\hline \multicolumn{2}{|l|}{ Total gap length, in percent } & 65.3 \\
\hline Mean basal gap length, in centimeters & & 125 \\
\hline
\end{tabular}


Table 4. Vegetation cover and substrate measured in August 2010 in the study area near Teesto Wash, Navajo Nation, Arizona.-Continued

Site 3

\begin{tabular}{|c|c|c|}
\hline Vegetation & $\begin{array}{l}\text { Area, in square } \\
\text { meters }\end{array}$ & Percentage \\
\hline Mojave indigobush (Psorothamnus arborescens) & 16.5 & 11.7 \\
\hline Russian thistle (Salsola sp.) & 6.29 & 4.45 \\
\hline Rabbitbrush (Ericameria nauseosus) & 5.02 & 3.55 \\
\hline Stickleaf (Mentzelia pumila) & 2.90 & 2.05 \\
\hline Sandhill muhly (Muhlenbergia pungens) & 2.26 & 1.60 \\
\hline Giant dropseed (Sporobolus giganteus) & 2.23 & 1.58 \\
\hline Plains spring parsley (Cymopterus acaulis) & 1.41 & 1.00 \\
\hline Unidentified shrub, dead & 1.27 & 0.90 \\
\hline Indian ricegrass (Oryzopsis hymenoides) & 0.59 & 0.42 \\
\hline Doveweed (Croton texensis) & 0.57 & 0.40 \\
\hline Dicoria (Dicoria canescens) & 0.30 & 0.21 \\
\hline Snakeweed (Gutierrezia sarothrae) & 0.28 & 0.20 \\
\hline Galleta grass (Pleuraphis jamesii) & 0.18 & 0.13 \\
\hline Alkali sacoton (Sporobolus airoides) & 0.14 & 0.10 \\
\hline Globemallow (Sphaeralcea sp.) & 0.14 & 0.10 \\
\hline Unidentified annual grass & 0.11 & 0.08 \\
\hline Total vegetation cover & 40.2 & 28.5 \\
\hline Substrate & $\begin{array}{c}\text { Area, in square } \\
\text { meters }\end{array}$ & Percentage \\
\hline Sand & 141 & 100 \\
\hline Rock & 0 & 0 \\
\hline Leaf litter & 0.14 & 0.10 \\
\hline Biologic soil crust & 0 & 0 \\
\hline Total gap length, in percent & & 62.4 \\
\hline Mean basal gap length, in centimeters & & 121 \\
\hline
\end{tabular}


Table 4. Vegetation cover and substrate measured in August 2010 in the study area near Teesto Wash, Navajo Nation, Arizona.-Continued

Site 4

\begin{tabular}{|c|c|c|}
\hline Vegetation & $\begin{array}{c}\text { Area, in square } \\
\text { meters }\end{array}$ & Percentage \\
\hline Mojave indigobush (Psorothamnus arborescens) & 19.4 & 13.7 \\
\hline Russian thistle (Salsola sp.) & 10.6 & 7.50 \\
\hline Stickleaf (Mentzelia pumila) & 9.19 & 6.50 \\
\hline Rabbitbrush (Ericameria nauseosus) & 2.26 & 1.60 \\
\hline Doveweed (Croton texensis) & 1.41 & 1.00 \\
\hline Silverleaf nightshade (Solanum elaeagnifolium) & 1.20 & 0.85 \\
\hline Bindweed heliotrope (Heliotropium convolvulaceum) & 1.15 & 0.81 \\
\hline Unidentified forb, dead & 1.13 & 0.80 \\
\hline Indian ricegrass (Oryzopsis hymenoides) & 0.98 & 0.69 \\
\hline Plains spring parsley (Cymopterus acaulis) & 0.95 & 0.67 \\
\hline Unidentified annual grass & 0.71 & 0.50 \\
\hline Snakeweed (Gutierrezia sarothrae) & 0.57 & 0.40 \\
\hline Globemallow (Sphaeralcea sp.) & 0.49 & 0.35 \\
\hline Unidentified perennial grasses & 0.49 & 0.35 \\
\hline Dicoria (Dicoria canescens) & 0.23 & 0.16 \\
\hline Sandhill muhly (Muhlenbergia pungens) & 0.14 & 0.10 \\
\hline Unidentified shrubs, dead & 0.14 & 0.10 \\
\hline Spike dropseed (Sporobolus contractus) & 0.07 & 0.05 \\
\hline Galleta grass (Pleuraphis jamesii) & 0.04 & 0.03 \\
\hline Total vegetation cover & 51.2 & 36.2 \\
\hline Substrate & $\begin{array}{c}\text { Area, in square } \\
\text { meters }\end{array}$ & Percentage \\
\hline Sand & 141.32 & 99.96 \\
\hline Rock & 0.06 & 0.04 \\
\hline Leaf litter & 0 & 0 \\
\hline Biologic soil crust & 0 & 0 \\
\hline \multicolumn{2}{|l|}{ Total gap length, in percent } & 64.0 \\
\hline Mean basal gap length, in centimeters & & 143 \\
\hline
\end{tabular}


Table 4. Vegetation cover and substrate measured in August 2010 in the study area near Teesto Wash, Navajo Nation, Arizona.-Continued

Site 5

\begin{tabular}{|c|c|c|}
\hline Vegetation & $\begin{array}{l}\text { Area, in square } \\
\text { meters }\end{array}$ & Percentage \\
\hline Mojave indigobush (Psorothamnus arborescens) & 13.3 & 9.40 \\
\hline Stickleaf (Mentzelia pumila) & 11.2 & 7.90 \\
\hline Rabbitbrush (Ericameria nauseosus) & 7.63 & 5.40 \\
\hline Silverleaf nightshade (Solanum elaeagnifolium) & 6.29 & 4.45 \\
\hline Snakeweed (Gutierrezia sarothrae), dead & 3.89 & 2.75 \\
\hline Plains spring parsley (Cymopterus acaulis) & 3.82 & 2.70 \\
\hline Doveweed (Croton texensis) & 3.34 & 2.36 \\
\hline Russian thistle (Salsola sp.) & 2.47 & 1.75 \\
\hline Bindweed heliotrope (Heliotropium convolvulaceum) & 1.41 & 1.00 \\
\hline Unidentified perennial grass & 0.85 & 0.60 \\
\hline Indian ricegrass (Oryzopsis hymenoides) & 0.59 & 0.42 \\
\hline Unidentified annual grass & 0.54 & 0.38 \\
\hline Snakeweed (Gutierrezia sp.) & 0.49 & 0.35 \\
\hline Dicoria (Dicoria canescens) & 0.11 & 0.08 \\
\hline Unidentified annual forb & 0.08 & 0.06 \\
\hline Total vegetation cover & 56.0 & 39.6 \\
\hline Substrate & $\begin{array}{l}\text { Area, in square } \\
\text { meters }\end{array}$ & Percentage \\
\hline Sand & 141 & 100 \\
\hline Rock & 0 & 0 \\
\hline Leaf litter & 0 & 0 \\
\hline Biologic soil crust & 0 & 0 \\
\hline Total gap length, in percent & & 61.3 \\
\hline Mean basal gap length, in centimeters & & 267 \\
\hline
\end{tabular}


Table 4. Vegetation cover and substrate measured in August 2010 in the study area near Teesto Wash, Navajo Nation, Arizona.-Continued

Site 6

\begin{tabular}{|c|c|c|}
\hline Vegetation & $\begin{array}{c}\text { Area, in square } \\
\text { meters }\end{array}$ & Percentage \\
\hline Mojave indigobush (Psorothamnus arborescens) & 23.5 & 16.6 \\
\hline Stickleaf (Mentzelia pumila) & 11.6 & 8.20 \\
\hline Russian thistle (Salsola sp.) & 10.9 & 7.70 \\
\hline Plains spring parsley (Cymopterus acaulis) & 7.35 & 5.20 \\
\hline Doveweed (Croton texensis) & 3.25 & 2.30 \\
\hline Rabbitbrush (Ericameria nauseosus) & 3.25 & 2.30 \\
\hline Indian ricegrass (Oryzopsis hymenoides) & 1.34 & 0.95 \\
\hline Unidentified annual forb & 1.27 & 0.90 \\
\hline Unidentified dead plant & 0.92 & 0.65 \\
\hline Sand dropseed (Sporobolus cryptandrus) & 0.71 & 0.50 \\
\hline Giant dropseed (Sporobolus giganteus) & 0.14 & 0.10 \\
\hline Alkali sacoton (Sporobolus airoides) & 0.07 & 0.05 \\
\hline Galleta grass (Pleuraphis jamesii) & 0.04 & 0.03 \\
\hline Total vegetation cover & 64.3 & 45.5 \\
\hline Substrate & $\begin{array}{c}\text { Area, in square } \\
\text { meters }\end{array}$ & Percentage \\
\hline Sand & 141.1 & 99.8 \\
\hline Rock & 0 & 0 \\
\hline Leaf litter & 0.28 & 0.20 \\
\hline Biologic soil crust & 0 & 0 \\
\hline \multicolumn{2}{|l|}{ Total gap length, in percent } & 61.7 \\
\hline Mean basal gap length, in centimeters & & 148 \\
\hline
\end{tabular}


Table 4. Vegetation cover and substrate measured in August 2010 in the study area near Teesto Wash, Navajo Nation, Arizona.-Continued

Site 7

\begin{tabular}{|c|c|c|}
\hline Vegetation & $\begin{array}{c}\text { Area, in square } \\
\text { meters }\end{array}$ & Percentage \\
\hline Rabbitbrush (Ericameria nauseosus) & 22.3 & 15.8 \\
\hline Mojave indigobush (Psorothamnus arborescens) & 5.94 & 4.20 \\
\hline Sandhill muhly (Muhlenbergia pungens) & 5.09 & 3.60 \\
\hline Stickleaf (Mentzelia pumila) & 4.17 & 2.95 \\
\hline Russian thistle (Salsola $\mathrm{sp.}$ ) & 3.65 & 2.58 \\
\hline Plains spring parsley (Cymopterus acaulis) & 2.40 & 1.70 \\
\hline Doveweed (Croton texensis) & 2.33 & 1.65 \\
\hline Giant dropseed (Sporobolus giganteus) & 1.41 & 1.00 \\
\hline Indian ricegrass (Oryzopsis hymenoides) & 1.17 & 0.83 \\
\hline Alkali sacoton (Sporobolus airoides) & 0.85 & 0.60 \\
\hline Unidentified dead plants & 0.71 & 0.50 \\
\hline Sand dropseed (Sporobolus cryptandrus) & 0.65 & 0.46 \\
\hline Unidentified annual grass & 0.57 & 0.40 \\
\hline Ephedra (Ephedra sp.) & 0.42 & 0.30 \\
\hline Saltbush (Atriplex canescens) & 0.42 & 0.30 \\
\hline Dicoria (Dicoria canescens) & 0.14 & 0.10 \\
\hline Snakeweed (Gutierrezia sarothrae) & 0.08 & 0.06 \\
\hline Total vegetation cover & 52.3 & 37.0 \\
\hline Substrate & $\begin{array}{c}\text { Area, in square } \\
\text { meters }\end{array}$ & Percentage \\
\hline Sand & 132 & 93.6 \\
\hline Rock & 7.49 & 5.30 \\
\hline Leaf litter & 1.56 & 1.10 \\
\hline Biologic soil crust & 0 & 0 \\
\hline \multicolumn{2}{|l|}{ Total gap length, in percent } & 48.4 \\
\hline Mean basal gap length, in centimeters & & 103 \\
\hline
\end{tabular}


Table 4. Vegetation cover and substrate measured in August 2010 in the study area near Teesto Wash, Navajo Nation, Arizona.-Continued

Site 8

\begin{tabular}{lcc}
\hline \multicolumn{1}{c}{ Vegetation } & $\begin{array}{c}\text { Area, in square } \\
\text { meters }\end{array}$ & Percentage \\
\hline Silverleaf nightshade (Solanum elaeagnifolium) & 22.5 & 15.9 \\
Russian thistle (Salsola sp.) & 11.9 & 8.40 \\
Sand dropseed (Sporobolus cryptandrus) & 10.0 & 7.10 \\
Doveweed (Croton texensis) & 6.36 & 4.50 \\
Unidentified dead plants & 0.99 & 0.70 \\
Unidentified perennial grass & 0.57 & 0.40 \\
Pigweed (Amaranthus sp.) & 0.14 & 0.10 \\
Sandhill muhly (Muhlenbergia pungens) & 0.14 & 0.10 \\
Bindweed heliotrope (Heliotropium convolvulaceum) & 0.04 & 0.03 \\
\hline Total vegetation cover & 52.6 & 37.2 \\
\hline \multicolumn{1}{c}{ Substrate } & Area, in square & Percentage \\
\hline Sand & meters & 97.7 \\
Rock & 138 & 0.20 \\
Leaf litter & 0.28 & 2.10 \\
Biologic soil crust & 2.97 & 0 \\
\hline Total gap length, in percent & 0 & 58.7 \\
\hline Mean basal gap length, in centimeters & & 108 \\
\hline
\end{tabular}


Table 4. Vegetation cover and substrate measured in August 2010 in the study area near Teesto Wash, Navajo Nation, Arizona.-Continued

Site 9

\begin{tabular}{lcc}
\hline \multicolumn{1}{c}{ Vegetation } & $\begin{array}{c}\text { Area, in square } \\
\text { meters }\end{array}$ & Percentage \\
\hline Mojave indigobush (Psorothamnus arborescens) & 17.8 & 12.6 \\
Rabbitbrush (Ericameria nauseosus) & 9.61 & 6.80 \\
Unidentified annual forbs & 6.22 & 4.40 \\
Stickleaf (Mentzelia pumila) & 4.81 & 3.40 \\
Unidentified dead plants & 3.53 & 2.50 \\
Unidentified dead shrub & 1.27 & 0.90 \\
Doveweed (Croton texensis) & 0.95 & 0.68 \\
Unidentified annual grass & 0.68 & 0.48 \\
Russian thistle (Salsola sp.) & 0.52 & 0.37 \\
Plains spring parsley (Cymopterus acaulis) & 0.14 & 0.10 \\
Globemallow (Sphaeralcea sp.) & 0.10 & 0.07 \\
\hline Total vegetation cover & 45.7 & 32.3 \\
\hline \multicolumn{1}{c}{ Substrate } & Area, in square & Percentage \\
\hline Leaf litter & 78.8 & 24.3 \\
\hline Biologic soil crust & 24.3 & 55.8 \\
\hline Motal gap length, in percent & 3.25 & 17.2 \\
\hline Rock & 35.0 & 2.30 \\
\hline & & 444 \\
\hline
\end{tabular}


Table 4. Vegetation cover and substrate measured in August 2010 in the study area near Teesto Wash, Navajo Nation, Arizona.-Continued

Site 10

\begin{tabular}{|c|c|c|}
\hline Vegetation & $\begin{array}{c}\text { Area, in square } \\
\text { meters }\end{array}$ & Percentage \\
\hline Rabbitbrush (Ericameria nauseosus) & 15.6 & 11.0 \\
\hline Stickleaf (Mentzelia pumila) & 7.35 & 5.20 \\
\hline Mojave indigobush (Psorothamnus arborescens) & 6.64 & 4.70 \\
\hline Unidentified dead shrubs & 3.11 & 2.20 \\
\hline Russian thistle (Salsola sp.) & 2.12 & 1.50 \\
\hline Plains spring parsley (Cymopterus acaulis) & 1.27 & 0.90 \\
\hline Unidentified perennial grass & 0.85 & 0.60 \\
\hline Unidentified dead plants & 0.71 & 0.50 \\
\hline Unidentified annual forb & 0.42 & 0.30 \\
\hline Unidentified annual forb (second) & 0.42 & 0.30 \\
\hline Snakeweed (Gutierrezia sarothrae) & 0.28 & 0.20 \\
\hline Indian ricegrass (Oryzopsis hymenoides) & 0.14 & 0.10 \\
\hline Doveweed (Croton texensis) & 0.14 & 0.10 \\
\hline Pigweed (Amaranthus sp.) & 0.07 & 0.05 \\
\hline Milkvetch (Astragalus sp.) & 0.07 & 0.05 \\
\hline Total vegetation cover & 39.2 & 27.7 \\
\hline Substrate & $\begin{array}{c}\text { Area, in square } \\
\text { meters }\end{array}$ & Percentage \\
\hline Sand & 130 & 92.1 \\
\hline Rock & 10.5 & 7.40 \\
\hline Leaf litter & 0.71 & 0.50 \\
\hline Biologic soil crust & 0 & 0 \\
\hline \multicolumn{2}{|l|}{ Total gap length, in percent } & 13.0 \\
\hline Mean basal gap length, in centimeters & & 666 \\
\hline
\end{tabular}


Table 4. Vegetation cover and substrate measured in August 2010 in the study area near Teesto Wash, Navajo Nation, Arizona._-Continued

Site 11

\begin{tabular}{lcc}
\hline \multicolumn{1}{c}{ Vegetation } & $\begin{array}{c}\text { Area, in square } \\
\text { meters }\end{array}$ & Percentage \\
\hline Unidentified annual forb & 14.1 & 10.0 \\
Stickleaf (Mentzelia pumila) & 12.2 & 8.60 \\
Russian thistle (Salsola sp.) & 11.5 & 8.10 \\
Mojave indigobush (Psorothamnus arborescens) & 9.90 & 7.00 \\
Unidentified annual forb (second) & 3.39 & 2.40 \\
Unidentified dead plants & 2.54 & 1.80 \\
Plains spring parsley (Cymopterus acaulis) & 1.34 & 0.95 \\
Indian ricegrass (Oryzopsis hymenoides) & 0.85 & 0.60 \\
Unidentified perennial grass & 0.57 & 0.40 \\
Bindweed heliotrope (Heliotropium convolvulaceum) & 0.35 & 0.25 \\
Sand dropseed (Sporobolus cryptandrus) & 0.14 & 0.10 \\
\hline Total vegetation cover & 56.8 & 40.2 \\
\hline & Area, in square & Percentage \\
\hline Sand & meters & 98.9 \\
Rock & 139.8 & 0 \\
Leaf litter & 0 & 1.10 \\
\hline Total gap length, in percent & 1.56 & 0 \\
\hline Mean basal gap length, in centimeters & 0 & 00 \\
\hline & & \\
\hline & & 0.6 \\
\hline
\end{tabular}


Table 5. Vegetation cover and substrate measured in March 2011 in the study area near Teesto Wash, Navajo Nation, Arizona.

[Coverage is given in terms of area and percentage within five circles of radius $3 \mathrm{~m}$, as shown in figure 3]

Site 1

\begin{tabular}{|c|c|c|}
\hline Vegetation & $\begin{array}{c}\text { Area, in square } \\
\text { meters }\end{array}$ & Percentage \\
\hline Galleta grass (Pleuraphis jamesii) & 13.9 & 9.80 \\
\hline Mojave indigobush (Psorothamnus arborescens) & 2.54 & 1.80 \\
\hline Russian thistle (Salsola sp.) & 1.91 & 1.35 \\
\hline Stickleaf (Mentzelia pumila) & 1.63 & 1.15 \\
\hline Sandhill muhly (Muhlenbergia pungens) & 0.85 & 0.60 \\
\hline Indian ricegrass (Oryzopsis hymenoides) & 0.83 & 0.59 \\
\hline Rabbitbrush (Ericameria nauseosus) & 0.71 & 0.50 \\
\hline Snakeweed (Gutierrezia sarothrae), live & 0.61 & 0.43 \\
\hline Snakeweed (Gutierrezia sarothrae), dead & 0.57 & 0.40 \\
\hline Narrowleaf yucca (Yucca angustissima) & 0.42 & 0.30 \\
\hline Saltbush (Atriplex canescens) & 0.42 & 0.30 \\
\hline Sand dropseed (Sporobolus cryptandrus) & 0.20 & 0.14 \\
\hline Unidentified perennial grass, dead & 0.14 & 0.10 \\
\hline Sand verbena (Abronia fragrans) & 0.08 & 0.06 \\
\hline Unidentified forb & 0.07 & 0.05 \\
\hline Total vegetation cover & 24.8 & 17.6 \\
\hline Substrate & $\begin{array}{c}\text { Area, in square } \\
\text { meters }\end{array}$ & Percentage \\
\hline Sand & 139.1 & 98.4 \\
\hline Rock & 0.00 & 0.00 \\
\hline Leaf litter & 2.26 & 1.60 \\
\hline Biologic soil crust & 0.00 & 0.00 \\
\hline Russian-thistle litter & 0.71 & 0.50 \\
\hline \multicolumn{2}{|l|}{ Total gap length, in percent } & 70.1 \\
\hline Mean basal gap length, in centimeters & & 133 \\
\hline
\end{tabular}


Table 5. Vegetation cover and substrate measured in March 2011 in the study area near Teesto Wash, Navajo Nation, Arizona.-Continued

Site 2

\begin{tabular}{|c|c|c|}
\hline Vegetation & $\begin{array}{c}\text { Area, in square } \\
\text { meters }\end{array}$ & Percentage \\
\hline Mojave indigobush (Psorothamnus arborescens) & 12.6 & 8.90 \\
\hline Russian thistle (Salsola sp.) & 4.59 & 3.25 \\
\hline Rabbitbrush (Ericameria nauseosus) & 3.68 & 2.60 \\
\hline Sandhill muhly (Muhlenbergia pungens) & 3.32 & 2.35 \\
\hline Indian ricegrass (Oryzopsis hymenoides) & 2.12 & 1.50 \\
\hline Stickleaf (Mentzelia pumila) & 1.89 & 1.34 \\
\hline Snakeweed (Gutierrezia sarothrae), dead & 1.70 & 1.20 \\
\hline Galleta grass (Pleuraphis jamesii) & 1.41 & 1.00 \\
\hline Unidentified shrub, dead & 1.27 & 0.90 \\
\hline Unidentified perennial forb & 0.71 & 0.5 \\
\hline Giant dropseed (Sporobolus giganteus) & 0.61 & 0.43 \\
\hline Snakeweed (Gutierrezia sarothrae), live & 0.48 & 0.34 \\
\hline Total vegetation cover & 34.4 & 24.3 \\
\hline Substrate & $\begin{array}{c}\text { Area, in square } \\
\text { meters }\end{array}$ & Percentage \\
\hline Sand & 137 & 97.0 \\
\hline Rock & 0 & 0 \\
\hline Leaf litter & 4.24 & 3.00 \\
\hline Biologic soil crust & 0 & 0 \\
\hline$\underline{\text { Russian-thistle litter }}$ & 2.83 & 2.00 \\
\hline \multicolumn{2}{|l|}{ Total gap length, in percent } & 79.4 \\
\hline Mean basal gap length, in centimeters & & 222 \\
\hline
\end{tabular}


Table 5. Vegetation cover and substrate measured in March 2011 in the study area near Teesto Wash, Navajo Nation, Arizona.-Continued

Site 3

\begin{tabular}{|c|c|c|}
\hline Vegetation & $\begin{array}{c}\text { Area, in square } \\
\text { meters }\end{array}$ & Percentage \\
\hline Mojave indigobush (Psorothamnus arborescens) & 16.7 & 11.8 \\
\hline Russian thistle (Salsola sp.) & 5.80 & 4.10 \\
\hline Rabbitbrush (Ericameria nauseosus) & 4.03 & 2.85 \\
\hline Indian ricegrass (Oryzopsis hymenoides) & 2.33 & 1.65 \\
\hline Stickleaf (Mentzelia pumila) & 2.12 & 1.50 \\
\hline Sandhill muhly (Muhlenbergia pungens) & 1.84 & 1.30 \\
\hline Giant dropseed (Sporobolus giganteus) & 1.29 & 0.91 \\
\hline Unidentified plant & 0.64 & 0.45 \\
\hline Galleta grass (Pleuraphis jamesii) & 0.57 & 0.40 \\
\hline Snakeweed (Gutierrezia sarothrae) & 0.28 & 0.20 \\
\hline Total vegetation cover & 35.6 & 25.2 \\
\hline Substrate & $\begin{array}{c}\text { Area, in square } \\
\text { meters }\end{array}$ & Percentage \\
\hline Sand & 138 & 97.8 \\
\hline Rock & 0 & 0 \\
\hline Leaf litter & 3.11 & 2.20 \\
\hline Biologic soil crust & 0 & 0 \\
\hline Russian-thistle litter & 4.67 & 3.30 \\
\hline Total gap length, in percent & & 52.2 \\
\hline Mean basal gap length, in centimeters & & 118 \\
\hline
\end{tabular}


Table 5. Vegetation cover and substrate measured in March 2011 in the study area near Teesto Wash, Navajo Nation, Arizona.-Continued

Site 4

\begin{tabular}{lcc}
\hline \multicolumn{1}{c}{ Vegetation } & $\begin{array}{c}\text { Area, in square } \\
\text { meters }\end{array}$ & Percentage \\
\hline Mojave indigobush (Psorothamnus arborescens) & 22.1 & 15.6 \\
Russian thistle (Salsola sp.) & 8.91 & 6.30 \\
Stickleaf (Mentzelia pumila) & 3.24 & 2.29 \\
Indian ricegrass (Oryzopsis hymenoides) & 1.07 & 0.76 \\
Rabbitbrush (Ericameria nauseosus) & 0.85 & 0.60 \\
Snakeweed (Gutierrezia sarothrae), dead & 0.28 & 0.20 \\
Spike dropseed (Sporobolus contractus) & 0.28 & 0.20 \\
Plains spring parsley (Cymopterus acaulis) & 0.03 & 0.02 \\
Globemallow (Sphaeralcea sp.) & 0.03 & 0.02 \\
\hline Total vegetation cover & 36.7 & 26.0 \\
\hline \multicolumn{1}{c}{ Substrate } & Area, in square & Percentage \\
& meters & 98.3 \\
\hline Sand & 139 & 0 \\
Rock & 0 & 1.70 \\
Leaf litter & 2.40 & 0 \\
Biologic soil crust & 0 & 7.30 \\
Russian-thistle litter & 10.3 & 58.6 \\
\hline Total gap length, in percent & & 286 \\
\hline Mean basal gap length, in centimeters & &
\end{tabular}


Table 5. Vegetation cover and substrate measured in March 2011 in the study area near Teesto Wash, Navajo Nation, Arizona.-Continued

Site 5

\begin{tabular}{|c|c|c|}
\hline Vegetation & $\begin{array}{c}\text { Area, in square } \\
\text { meters }\end{array}$ & Percentage \\
\hline Rabbitbrush (Ericameria nauseosus) & 10.5 & 7.40 \\
\hline Mojave indigobush (Psorothamnus arborescens) & 9.75 & 6.90 \\
\hline Stickleaf (Mentzelia pumila) & 1.84 & 1.30 \\
\hline Russian thistle (Salsola sp.) & 1.77 & 1.25 \\
\hline Snakeweed (Gutierrezia sarothrae), live & 1.63 & 1.15 \\
\hline Snakeweed (Gutierrezia sarothrae), dead & 0.57 & 0.40 \\
\hline Unidentified annual forb & 0.49 & 0.35 \\
\hline Unidentified plant & 0.42 & 0.30 \\
\hline Giant dropseed (Sporobolus giganteus) & 0.28 & 0.20 \\
\hline Indian ricegrass (Oryzopsis hymenoides) & 0.23 & 0.16 \\
\hline Silverleaf nightshade (Solanum elaeagnifolium) & 0.07 & 0.05 \\
\hline Unidentified perennial grass & 0.03 & 0.02 \\
\hline Plains spring parsley (Cymopterus acaulis) & 0.03 & 0.02 \\
\hline Total vegetation cover & 27.6 & 19.5 \\
\hline Substrate & $\begin{array}{c}\text { Area, in square } \\
\text { meters }\end{array}$ & Percentage \\
\hline Sand & 137 & 97.1 \\
\hline Rock & 0 & 0 \\
\hline Leaf litter & 3.96 & 2.80 \\
\hline Biologic soil crust & 0 & 0 \\
\hline Russian-thistle litter & 5.23 & 3.70 \\
\hline Total gap length, in percent & & 67.1 \\
\hline Mean basal gap length, in centimeters & & 400 \\
\hline
\end{tabular}


Table 5. Vegetation cover and substrate measured in March 2011 in the study area near Teesto Wash, Navajo Nation, Arizona.-Continued

Site 6

\begin{tabular}{|c|c|c|}
\hline Vegetation & $\begin{array}{l}\text { Area, in square } \\
\text { meters }\end{array}$ & Percentage \\
\hline Mojave indigobush (Psorothamnus arborescens) & 8.48 & 6.00 \\
\hline Rabbitbrush (Ericameria nauseosus) & 7.21 & 5.10 \\
\hline Russian thistle (Salsola sp.) & 2.32 & 1.64 \\
\hline Stickleaf (Mentzelia pumila) & 2.12 & 1.50 \\
\hline Sand dropseed (Sporobolus cryptandrus) & 0.99 & 0.70 \\
\hline Giant dropseed (Sporobolus giganteus) & 0.98 & 0.69 \\
\hline Indian ricegrass (Oryzopsis hymenoides) & 0.68 & 0.48 \\
\hline Unidentified annual forb & 0.57 & 0.40 \\
\hline Unidentified perennial forb & 0.31 & 0.22 \\
\hline Rabbitbrush (Ericameria nauseosus), dead & 0.28 & 0.20 \\
\hline Snakeweed (Gutierrezia sarothrae), dead & 0.23 & 0.16 \\
\hline Unidentified plant & 0.14 & 0.10 \\
\hline Grama grass (Bouteloua sp.) & 0.08 & 0.06 \\
\hline Sandhill muhly (Muhlenbergia pungens) & 0.07 & 0.05 \\
\hline Total vegetation cover & 24.5 & 17.3 \\
\hline Substrate & $\begin{array}{c}\text { Area, in square } \\
\text { meters }\end{array}$ & Percentage \\
\hline Sand & 139 & 98.5 \\
\hline Rock & 0 & 0 \\
\hline Leaf litter & 1.98 & 1.40 \\
\hline Biologic soil crust & 0 & 0 \\
\hline Russian-thistle litter & 2.40 & 1.70 \\
\hline \multicolumn{2}{|l|}{ Total gap length, in percent } & 69.1 \\
\hline Mean basal gap length, in centimeters & & 400 \\
\hline
\end{tabular}


Table 5. Vegetation cover and substrate measured in March 2011 in the study area near Teesto Wash, Navajo Nation, Arizona.-Continued

Site 7

\begin{tabular}{|c|c|c|}
\hline Vegetation & $\begin{array}{c}\text { Area, in square } \\
\text { meters }\end{array}$ & Percentage \\
\hline Rabbitbrush (Ericameria nauseosus) & 13.9 & 9.80 \\
\hline Russian thistle (Salsola sp.) & 4.21 & 2.98 \\
\hline Mojave indigobush (Psorothamnus arborescens) & 3.96 & 2.80 \\
\hline Galleta grass (Pleuraphis jamesii) & 3.39 & 2.40 \\
\hline Unidentified plant & 0.85 & 0.60 \\
\hline Indian ricegrass (Oryzopsis hymenoides) & 0.75 & 0.53 \\
\hline Sandhill muhly (Muhlenbergia pungens) & 0.71 & 0.50 \\
\hline Ephedra (Ephedra sp.) & 0.65 & 0.46 \\
\hline Giant dropseed (Sporobolus giganteus) & 0.64 & 0.45 \\
\hline Stickleaf (Mentzelia pumila) & 0.57 & 0.40 \\
\hline Sand dropseed (Sporobolus cryptandrus) & 0.42 & 0.30 \\
\hline Saltbush (Atriplex canescens) & 0.34 & 0.24 \\
\hline Snakeweed (Gutierrezia sarothrae) & 0.14 & 0.10 \\
\hline Total vegetation cover & 30.5 & 21.6 \\
\hline Substrate & $\begin{array}{c}\text { Area, in square } \\
\text { meters }\end{array}$ & Percentage \\
\hline Sand & 130 & 92.2 \\
\hline Rock & 8.77 & 6.20 \\
\hline Leaf litter & 2.26 & 1.60 \\
\hline Biologic soil crust & 0 & 0 \\
\hline Russian-thistle litter & 6.50 & 4.60 \\
\hline Total gap length, in percent & & 52.5 \\
\hline Mean basal gap length, in centimeters & & 222 \\
\hline
\end{tabular}


Table 5. Vegetation cover and substrate measured in March 2011 in the study area near Teesto Wash, Navajo Nation, Arizona.-Continued

Site 8

\begin{tabular}{|c|c|c|}
\hline Vegetation & $\begin{array}{l}\text { Area, in square } \\
\text { meters }\end{array}$ & Percentage \\
\hline Sand dropseed (Sporobolus cryptandrus) & 6.43 & 4.55 \\
\hline Russian thistle (Salsola sp.) & 4.67 & 3.30 \\
\hline Galleta grass (Pleuraphis jamesii) & 1.70 & 1.20 \\
\hline Unidentified plant & 0.99 & 0.70 \\
\hline Unidentified perennial grass & 0.57 & 0.40 \\
\hline Unidentified perennial forb & 0.42 & 0.30 \\
\hline Silverleaf nightshade (Solanum elaeagnifolium) & 0.28 & 0.20 \\
\hline Unidentified annual forb & 0.14 & 0.10 \\
\hline Indian ricegrass (Oryzopsis hymenoides) & 0.06 & 0.04 \\
\hline Globemallow (Sphaeralcea sp.) & 0.06 & 0.04 \\
\hline Snakeweed (Gutierrezia sarothrae), dead & 0.06 & 0.04 \\
\hline Total vegetation cover & 15.4 & 10.9 \\
\hline Substrate & $\begin{array}{c}\text { Area, in square } \\
\text { meters }\end{array}$ & Percentage \\
\hline Sand & 137 & 96.6 \\
\hline Rock & 0.59 & 0.42 \\
\hline Leaf litter & 4.24 & 3.00 \\
\hline Biologic soil crust & 0 & 0 \\
\hline$\underline{\text { Russian-thistle litter }}$ & 1.84 & 1.30 \\
\hline Total gap length, in percent & & 75.3 \\
\hline Mean basal gap length, in centimeters & & 148 \\
\hline
\end{tabular}


Table 5. Vegetation cover and substrate measured in March 2011 in the study area near Teesto Wash, Navajo Nation, Arizona.-Continued

Site 9

\begin{tabular}{lcc}
\hline \multicolumn{1}{c}{ Vegetation } & $\begin{array}{c}\text { Area, in square } \\
\text { meters }\end{array}$ & Percentage \\
\hline Mojave indigobush (Psorothamnus arborescens) & 13.7 & 9.70 \\
Rabbitbrush (Ericameria nauseosus) & 2.26 & 1.60 \\
Stickleaf (Mentzelia pumila) & 1.87 & 1.32 \\
Unidentified shrub, dead & 1.13 & 0.80 \\
Russian thistle (Salsola sp.) & 0.85 & 0.60 \\
Rabbitbrush (Ericameria nauseosus), dead & 0.71 & 0.50 \\
Grama grass (Bouteloua sp.) & 0.49 & 0.35 \\
\hline Total vegetation cover & 21.0 & 14.9 \\
\hline \multicolumn{1}{c}{ Substrate } & Area, in square & Percentage \\
\hline Sand & meters & 71.1 \\
Rock & 100 & 11.2 \\
Leaf litter & 15.8 & 2.05 \\
Biologic soil crust & 2.90 & 15.7 \\
Russian-thistle litter & 22.2 & 1.70 \\
\hline Total gap length, in percent & 2.40 & 41.0 \\
\hline Mean basal gap length, in centimeters & & 1333 \\
& &
\end{tabular}

Site 10

\begin{tabular}{lcc}
\hline \multicolumn{1}{c}{ Vegetation } & $\begin{array}{c}\text { Area, in square } \\
\text { meters }\end{array}$ & Percentage \\
\hline Rabbitbrush (Ericameria nauseosus) & 11.7 & 8.30 \\
Mojave indigobush (Psorothamnus arborescens) & 6.36 & 4.50 \\
Stickleaf (Mentzelia pumila) & 1.98 & 1.40 \\
Russian thistle (Salsola sp.) & 1.41 & 1.00 \\
Rabbitbrush (Ericameria nauseosus), dead & 0.42 & 0.30 \\
Ephedra (Ephedra sp.), dead & 0.42 & 0.30 \\
Indian ricegrass (Oryzopsis hymenoides) & 0.20 & 0.14 \\
Unidentified shrubs, dead & 0.14 & 0.10 \\
\hline Total vegetation cover & 22.7 & 16.0 \\
\hline \multicolumn{1}{c}{ Substrate } & Area, in square & Percentage \\
\hline Sand & meters & 86.9 \\
Rock & 123 & 10.2 \\
Leaf litter & 14.4 & 0.90 \\
Biologic soil crust & 1.27 & 2.00 \\
Russian-thistle litter & 2.83 & 0.50 \\
\hline Total gap length, in percent & 0.71 & 58.5 \\
\hline Mean basal gap length, in centimeters & & 2000 \\
\hline
\end{tabular}


Table 5. Vegetation cover and substrate measured in March 2011 in the study area near Teesto Wash, Navajo Nation, Arizona.-Continued

Site 11

\begin{tabular}{lcc}
\hline \multicolumn{1}{c}{ Vegetation } & $\begin{array}{c}\text { Area, in square } \\
\text { meters }\end{array}$ & Percentage \\
\hline Mojave indigobush (Psorothamnus arborescens) & 17.2 & 12.2 \\
Russian thistle (Salsola sp.) & 4.61 & 3.26 \\
Stickleaf (Mentzelia pumila) & 2.71 & 1.92 \\
Rabbitbrush (Ericameria nauseosus) & 2.26 & 1.60 \\
Indian ricegrass (Oryzopsis hymenoides) & 0.85 & 0.60 \\
Unidentified forbs & 0.37 & 0.26 \\
Giant dropseed (Sporobolus giganteus) & 0.28 & 0.20 \\
Snakeweed (Gutierrezia sarothrae), dead & 0.28 & 0.20 \\
Sand dropseed (Sporobolus cryptandrus) & 0.14 & 0.10 \\
Unidentified aster (Asteraceae family) & 0.08 & 0.06 \\
\hline Total vegetation cover & 28.8 & 20.4 \\
\hline \multicolumn{1}{c}{ Substrate } & Area, in square & Percentage \\
\hline mand & meters & 97.0 \\
Rock & 137 & 0 \\
Leaf litter & 0 & 2.90 \\
Biologic soil crust & 4.10 & 0.06 \\
Russian-thistle litter & 0.08 & 3.30 \\
\hline Total gap length, in percent & 4.67 & 64.7 \\
\hline Mean basal gap length, in centimeters & & \\
\hline & & \\
\hline & & \\
\hline
\end{tabular}


Table 6. Vegetation cover and substrate measured in August 2011 in the study area near Teesto Wash, Navajo Nation, Arizona.

[Coverage is given in terms of area and percentage within five circles of radius $3 \mathrm{~m}$, as shown in figure 3]

Site 1

\begin{tabular}{|c|c|c|}
\hline Vegetation & $\begin{array}{c}\text { Area, in square } \\
\text { meters }\end{array}$ & Percentage \\
\hline Unidentified perennial grass, dead & 11.3 & 8.00 \\
\hline Mojave indigobush (Psorothamnus arborescens) & 5.51 & 3.90 \\
\hline Sand dropseed (Sporobolus cryptandrus) & 1.84 & 1.30 \\
\hline Sandhill muhly (Muhlenbergia pungens) & 1.41 & 1.00 \\
\hline Russian thistle (Salsola sp.) & 0.92 & 0.65 \\
\hline Saltbush (Atriplex canescens) & 0.57 & 0.40 \\
\hline Narrowleaf yucca (Yucca angustissima) & 0.57 & 0.40 \\
\hline Rabbitbrush (Ericameria nauseosus) & 0.57 & 0.40 \\
\hline Stickleaf (Mentzelia pumila) & 0.42 & 0.30 \\
\hline Indian ricegrass (Oryzopsis hymenoides) & 0.42 & 0.30 \\
\hline Snakeweed (Gutierrezia sarothrae) & 0.39 & 0.28 \\
\hline Unidentified shrub, dead & 0.35 & 0.25 \\
\hline Alkali sacoton (Sporobolus airoides) & 0.28 & 0.20 \\
\hline Snakeweed (Gutierrezia sp.), dead & 0.14 & 0.10 \\
\hline Total vegetation cover & 24.7 & 17.5 \\
\hline Substrate & $\begin{array}{c}\text { Area, in square } \\
\text { meters }\end{array}$ & Percentage \\
\hline Sand & 139 & 98.0 \\
\hline Rock & 0 & 0 \\
\hline Leaf litter & 2.83 & 2.00 \\
\hline Biologic soil crust & 0 & 0 \\
\hline Russian-thistle litter & 0.28 & 0.20 \\
\hline \multicolumn{2}{|l|}{ Total gap length, in percent } & 79.5 \\
\hline Mean basal gap length, in centimeters & & 129 \\
\hline
\end{tabular}


Table 6. Vegetation cover and substrate measured in August 2011 in the study area near Teesto Wash, Navajo Nation, Arizona.-Continued

Site 2

\begin{tabular}{lcc}
\hline \multicolumn{1}{c}{ Vegetation } & $\begin{array}{c}\text { Area, in square } \\
\text { meters }\end{array}$ & Percentage \\
\hline Mojave indigobush (Psorothamnus arborescens) & 9.90 & 7.00 \\
Rabbitbrush (Ericameria nauseosus) & 3.11 & 2.20 \\
Sandhill muhly (Muhlenbergia pungens) & 2.97 & 2.10 \\
Unidentified perennial grass & 1.91 & 1.35 \\
Unidentified shrub, dead & 1.13 & 0.80 \\
Indian ricegrass (Oryzopsis hymenoides) & 0.75 & 0.53 \\
Russian thistle (Salsola sp.) & 0.57 & 0.40 \\
Stickleaf (Mentzelia pumila) & 0.51 & 0.36 \\
Snakeweed (Gutierrezia sarothrae) & 0.39 & 0.28 \\
Giant dropseed (Sporobolus giganteus) & 0.35 & 0.25 \\
Spike dropseed (Sporobolus contractus) & 0.21 & 0.15 \\
Unidentified perennial forb & 0.14 & 0.10 \\
Snakeweed (Gutierrezia sarothrae), dead & 0.14 & 0.10 \\
Unidentified perennial forb, dead & 0.06 & 0.04 \\
\hline Total vegetation cover & 22.1 & 15.7 \\
\hline Substrate & Area, in square & Percentage \\
\hline Sand & 138 & 0.67 .8 \\
Rock & 0.85 & 0 \\
\hline Total gap length, in percent & 2.26 & 1.40 \\
\hline Mean basal gap length, in centimeters & 0 & 00 \\
\hline
\end{tabular}


Table 6. Vegetation cover and substrate measured in August 2011 in the study area near Teesto Wash, Navajo Nation, Arizona.-Continued

Site 3

\begin{tabular}{|c|c|c|}
\hline Vegetation & $\begin{array}{l}\text { Area, in square } \\
\text { meters }\end{array}$ & Percentage \\
\hline Mojave indigobush (Psorothamnus arborescens) & 9.61 & 6.80 \\
\hline Sandhill muhly (Muhlenbergia pungens) & 3.68 & 2.60 \\
\hline Rabbitbrush (Ericameria nauseosus) & 2.97 & 2.10 \\
\hline Russian thistle (Salsola sp.) & 2.76 & 1.95 \\
\hline Unidentified perennial grass & 2.33 & 1.65 \\
\hline Indian ricegrass (Oryzopsis hymenoides) & 1.06 & 0.75 \\
\hline Stickleaf (Mentzelia pumila) & 0.85 & 0.60 \\
\hline Giant dropseed (Sporobolus giganteus) & 0.57 & 0.40 \\
\hline Unidentified shrub, dead & 0.14 & 0.10 \\
\hline Snakeweed (Gutierrezia sarothrae) & 0.13 & 0.09 \\
\hline Spike dropseed (Sporobolus contractus) & 0.07 & 0.05 \\
\hline Total vegetation cover & 24.2 & 17.1 \\
\hline Substrate & $\begin{array}{c}\text { Area, in square } \\
\text { meters }\end{array}$ & Percentage \\
\hline Sand & 139 & 98.2 \\
\hline Rock & 0 & 0 \\
\hline Leaf litter & 2.54 & 1.80 \\
\hline Biologic soil crust & 0 & 0 \\
\hline Russian-thistle litter & 2.54 & 1.80 \\
\hline Total gap length, in percent & & 64.6 \\
\hline Mean basal gap length, in centimeters & & 191 \\
\hline
\end{tabular}


54 Vegetation, Substrate, and Eolian Sediment Transport at Teesto Wash, Navajo Nation, 2009-2012

Table 6. Vegetation cover and substrate measured in August 2011 in the study area near Teesto Wash, Navajo Nation, Arizona.-Continued

Site 4

\begin{tabular}{|c|c|c|}
\hline Vegetation & $\begin{array}{c}\text { Area, in square } \\
\text { meters }\end{array}$ & Percentage \\
\hline Mojave indigobush (Psorothamnus arborescens) & 20.4 & 14.4 \\
\hline Russian thistle (Salsola $\mathrm{sp.}$.) & 3.60 & 2.55 \\
\hline Rabbitbrush (Ericameria nauseosus) & 1.15 & 0.81 \\
\hline Stickleaf (Mentzelia pumila) & 1.03 & 0.73 \\
\hline Indian ricegrass (Oryzopsis hymenoides) & 0.49 & 0.35 \\
\hline Unidentified perennial grass & 0.20 & 0.14 \\
\hline Snakeweed (Gutierrezia sarothrae), dead & 0.07 & 0.05 \\
\hline Globemallow (Sphaeralcea sp.) & 0.03 & 0.02 \\
\hline Total vegetation cover & 26.9 & 19.1 \\
\hline Substrate & $\begin{array}{c}\text { Area, in square } \\
\text { meters }\end{array}$ & Percentage \\
\hline Sand & 139 & 98.0 \\
\hline Rock & 0 & 0 \\
\hline Leaf litter & 2.83 & 2.00 \\
\hline Biologic soil crust & 0 & 0 \\
\hline Russian-thistle litter & 3.11 & 2.20 \\
\hline Total gap length, in percent & & 70.1 \\
\hline Mean basal gap length, in centimeters & & 562 \\
\hline
\end{tabular}


Table 6. Vegetation cover and substrate measured in August 2011 in the study area near Teesto Wash, Navajo Nation, Arizona.-Continued

Site 5

\begin{tabular}{|c|c|c|}
\hline Vegetation & $\begin{array}{l}\text { Area, in square } \\
\text { meters }\end{array}$ & Percentage \\
\hline Rabbitbrush (Ericameria nauseosus) & 11.3 & 8.00 \\
\hline Mojave indigobush (Psorothamnus arborescens) & 7.35 & 5.20 \\
\hline Russian thistle (Salsola sp.) & 0.75 & 0.53 \\
\hline Snakeweed (Gutierrezia sarothrae) & 0.57 & 0.40 \\
\hline Snakeweed (Gutierrezia sarothrae), dead & 0.42 & 0.30 \\
\hline Silverleaf nightshade (Solanum elaeagnifolium) & 0.37 & 0.26 \\
\hline Indian ricegrass (Oryzopsis hymenoides) & 0.25 & 0.18 \\
\hline Unidentified perennial grass, dead & 0.21 & 0.15 \\
\hline Giant dropseed (Sporobolus giganteus) & 0.14 & 0.10 \\
\hline Stickleaf (Mentzelia pumila) & 0.07 & 0.05 \\
\hline Unidentified perennial grass & 0.04 & 0.03 \\
\hline Total vegetation cover & 21.5 & 15.2 \\
\hline Substrate & $\begin{array}{l}\text { Area, in square } \\
\text { meters }\end{array}$ & Percentage \\
\hline Sand & 134 & 94.5 \\
\hline Rock & 4.38 & 3.10 \\
\hline Leaf litter & 3.32 & 2.35 \\
\hline Biologic soil crust & 0 & 0 \\
\hline Russian-thistle litter & 3.96 & 2.80 \\
\hline Total gap length, in percent & & 75.1 \\
\hline Mean basal gap length, in centimeters & & 571 \\
\hline
\end{tabular}


Table 6. Vegetation cover and substrate measured in August 2011 in the study area near Teesto Wash, Navajo Nation, Arizona.-Continued

Site 6

\begin{tabular}{|c|c|c|}
\hline Vegetation & $\begin{array}{c}\text { Area, in square } \\
\text { meters }\end{array}$ & Percentage \\
\hline Mojave indigobush (Psorothamnus arborescens) & 9.19 & 6.50 \\
\hline Rabbitbrush (Ericameria nauseosus) & 4.24 & 3.00 \\
\hline Russian thistle (Salsola sp.) & 0.93 & 0.66 \\
\hline Unidentified perennial grass & 0.89 & 0.63 \\
\hline Snakeweed (Gutierrezia sarothrae) & 0.85 & 0.60 \\
\hline Unidentified shrub, dead & 0.71 & 0.50 \\
\hline Unidentified annual plants, dead & 0.57 & 0.40 \\
\hline Giant dropseed (Sporobolus giganteus) & 0.17 & 0.12 \\
\hline Indian ricegrass (Oryzopsis hymenoides) & 0.16 & 0.12 \\
\hline Snakeweed (Gutierrezia sarothrae), dead & 0.14 & 0.10 \\
\hline Stickleaf (Mentzelia pumila) & 0.10 & 0.07 \\
\hline Total vegetation cover & 17.9 & 12.7 \\
\hline Substrate & $\begin{array}{c}\text { Area, in square } \\
\text { meters }\end{array}$ & Percentage \\
\hline Sand & 137 & 97.2 \\
\hline Rock & 1.98 & 1.40 \\
\hline Leaf litter & 1.98 & 1.40 \\
\hline Biologic soil crust & 0 & 0 \\
\hline Russian-thistle litter & 2.33 & 1.65 \\
\hline Total gap length, in percent & & 63.8 \\
\hline Mean basal gap length, in centimeters & & 444 \\
\hline
\end{tabular}


Table 6. Vegetation cover and substrate measured in August 2011 in the study area near Teesto Wash, Navajo Nation, Arizona.-Continued

Site 7

\begin{tabular}{|c|c|c|}
\hline Vegetation & $\begin{array}{c}\text { Area, in square } \\
\text { meters }\end{array}$ & Percentage \\
\hline Mojave indigobush (Psorothamnus arborescens) & 9.19 & 6.50 \\
\hline Rabbitbrush (Ericameria nauseosus) & 9.19 & 6.50 \\
\hline Unidentified perennial grass & 1.70 & 1.20 \\
\hline Russian thistle (Salsola sp.) & 1.34 & 0.95 \\
\hline Unidentified annual plants, dead & 0.85 & 0.60 \\
\hline Sandhill muhly (Muhlenbergia pungens) & 0.42 & 0.30 \\
\hline Saltbush (Atriplex canescens) & 0.42 & 0.30 \\
\hline Sand dropseed (Sporobolus cryptandrus) & 0.42 & 0.30 \\
\hline Snakeweed (Gutierrezia sarothrae) & 0.42 & 0.30 \\
\hline Ephedra (Ephedra sp.) & 0.35 & 0.25 \\
\hline Giant dropseed (Sporobolus giganteus) & 0.35 & 0.25 \\
\hline Indian ricegrass (Oryzopsis hymenoides) & 0.28 & 0.20 \\
\hline Total vegetation cover & 25.0 & 17.7 \\
\hline Substrate & $\begin{array}{c}\text { Area, in square } \\
\text { meters }\end{array}$ & Percentage \\
\hline Sand & 126 & 89.3 \\
\hline Rock & 10.7 & 7.55 \\
\hline Leaf litter & 4.52 & 3.20 \\
\hline Biologic soil crust & 0 & 0 \\
\hline Russian-thistle litter & 5.51 & 3.90 \\
\hline Total gap length, in percent & & 57.6 \\
\hline Mean basal gap length, in centimeters & & 400 \\
\hline
\end{tabular}


Table 6. Vegetation cover and substrate measured in August 2011 in the study area near Teesto Wash, Navajo Nation, Arizona.-Continued

Site 8

\begin{tabular}{lcc}
\hline \multicolumn{1}{c}{ Vegetation } & $\begin{array}{c}\text { Area, in square } \\
\text { meters }\end{array}$ & Percentage \\
\hline Sand dropseed (Sporobolus cryptandrus) & 8.62 & 6.10 \\
Russian thistle (Salsola sp.) & 8.34 & 5.90 \\
Unidentified perennial grass & 3.68 & 2.60 \\
Silverleaf nightshade (Solanum elaeagnifolium) & 1.29 & 0.91 \\
\hline Total vegetation cover $\quad$ Substrate & 21.9 & 15.5 \\
\hline & Area, in square & Percentage \\
\hline Sand & meters & 90.1 \\
Rock & 127 & 2.32 \\
Leaf litter & 3.28 & 7.60 \\
Biologic soil crust & 10.7 & 0 \\
Russian-thistle litter & 0 & 0.10 \\
\hline Total gap length, in percent & 0.14 & 88.7 \\
\hline Mean basal gap length, in centimeters & & 167
\end{tabular}

Site 9

\begin{tabular}{lcc}
\hline \multicolumn{1}{c}{ Vegetation } & $\begin{array}{c}\text { Area, in square } \\
\text { meters }\end{array}$ & Percentage \\
\hline Mojave indigobush (Psorothamnus arborescens) & 14.6 & 10.3 \\
Rabbitbrush (Ericameria nauseosus) & 2.83 & 2.00 \\
Russian thistle (Salsola sp.) & 0.23 & 0.16 \\
Unidentified shrub, dead & 2.54 & 1.80 \\
Unidentified perennial forb, dead & 0.14 & 0.10 \\
Stickleaf (Mentzelia pumila) & 0.28 & 0.20 \\
\hline Total vegetation cover & 20.6 & 14.6 \\
\hline \multicolumn{1}{c}{ Substrate } & Area, in square & Percentage \\
\hline Sand & meters & 69.1 \\
Rock & 97.7 & 7.20 \\
Leaf litter & 10.2 & 4.70 \\
Biologic soil crust & 6.64 & 19.0 \\
Russian-thistle litter & 26.9 & 1.70 \\
\hline Total gap length, in percent & 2.40 & 34.6 \\
\hline Mean basal gap length, in centimeters & & 2000 \\
\hline
\end{tabular}


Table 6. Vegetation cover and substrate measured in August 2011 in the study area near Teesto Wash, Navajo Nation, Arizona.-Continued

Site 10

\begin{tabular}{|c|c|c|}
\hline Vegetation & $\begin{array}{c}\text { Area, in square } \\
\text { meters }\end{array}$ & Percentage \\
\hline Mojave indigobush (Psorothamnus arborescens) & 8.48 & 6.00 \\
\hline Rabbitbrush (Ericameria nauseosus) & 7.86 & 5.56 \\
\hline Russian thistle (Salsola sp.) & 1.19 & 0.84 \\
\hline Stickleaf (Mentzelia pumila) & 0.57 & 0.40 \\
\hline Unidentified shrub, dead & 0.57 & 0.40 \\
\hline Unidentified perennial grass & 0.03 & 0.02 \\
\hline Globemallow (Sphaeralcea sp.) & 0.03 & 0.02 \\
\hline Indian ricegrass (Oryzopsis hymenoides) & 0.31 & 0.22 \\
\hline Snakeweed (Gutierrezia sp.) & 0.14 & 0.10 \\
\hline Total vegetation cover & 19.2 & 13.6 \\
\hline Substrate & $\begin{array}{c}\text { Area, in square } \\
\text { meters }\end{array}$ & Percentage \\
\hline Sand & 132 & 93.4 \\
\hline Rock & 7.63 & 5.40 \\
\hline Leaf litter & 1.70 & 1.20 \\
\hline Biologic soil crust & 0 & 0 \\
\hline Russian-thistle litter & 2.12 & 1.50 \\
\hline Total gap length, in percent & & 51.2 \\
\hline Mean basal gap length, in centimeters & & 571 \\
\hline
\end{tabular}


Table 6. Vegetation cover and substrate measured in August 2011 in the study area near Teesto Wash, Navajo Nation, Arizona.-Continued

Site 11

\begin{tabular}{lcc}
\hline \multicolumn{1}{c}{ Vegetation } & $\begin{array}{c}\text { Area, in square } \\
\text { meters }\end{array}$ & Percentage \\
\hline Mojave indigobush (Psorothamnus arborescens) & 18.5 & 13.1 \\
Stickleaf (Mentzelia pumila) & 1.22 & 0.86 \\
Russian thistle (Salsola sp.) & 1.22 & 0.86 \\
Indian ricegrass (Oryzopsis hymenoides) & 0.62 & 0.44 \\
Unidentified shrub, dead & 0.57 & 0.40 \\
Rabbitbrush (Ericameria nauseosus) & 0.28 & 0.20 \\
Giant dropseed (Sporobolus giganteus) & 0.28 & 0.20 \\
Unidentified perennial grass, dead & 0.17 & 0.12 \\
Unidentified aster (Asteraceae family) & 0.08 & 0.06 \\
\hline Total vegetation cover & 23.0 & 16.2 \\
\hline \multicolumn{1}{c}{ Substrate } & Area, in square & Percentage \\
\hline mand & 137 & 96.6 \\
Rock & 0 & 0 \\
Leaf litter & 4.81 & 3.40 \\
Biologic soil crust & 0 & 0 \\
Russian-thistle litter & 1.98 & 1.40 \\
\hline Total gap length, in percent & & 62.2 \\
\hline Mean basal gap length, in centimeters & & 500 \\
\hline & & \\
\hline & & 0 \\
\hline
\end{tabular}


Table 7. Vegetation cover and substrate measured in March 2012 in the study area near Teesto Wash, Navajo Nation, Arizona.

[Coverage is given in terms of area and percentage within five circles of radius $3 \mathrm{~m}$, as shown in figure 3]

Site 1

\begin{tabular}{|c|c|c|}
\hline Vegetation & $\begin{array}{c}\text { Area, in square } \\
\text { meters }\end{array}$ & Percentage \\
\hline Unidentified perennial grass & 8.91 & 6.30 \\
\hline Mojave indigobush (Psorothamnus arborescens) & 4.24 & 30.00 \\
\hline Sandhill muhly (Muhlenbergia pungens) & 2.46 & 1.74 \\
\hline Stickleaf (Mentzelia pumila) & 0.91 & 0.64 \\
\hline Rabbitbrush (Ericameria nauseosus) & 0.64 & 0.45 \\
\hline Snakeweed (Gutierrezia sarothrae) & 0.57 & 0.40 \\
\hline Narrowleaf yucca (Yucca angustissima) & 0.57 & 0.40 \\
\hline Unidentified shrub, dead & 0.49 & 0.35 \\
\hline Russian thistle (Salsola sp.), dead & 0.48 & 0.34 \\
\hline Indian ricegrass (Oryzopsis hymenoides) & 0.37 & 0.26 \\
\hline Saltbush (Atriplex canescens) & 0.14 & 0.10 \\
\hline Unidentified annual forb; pigweed (Amaranthus sp.)? & trace & trace \\
\hline Total vegetation cover & 19.8 & 14.0 \\
\hline Substrate & $\begin{array}{l}\text { Area, in square } \\
\text { meters }\end{array}$ & Percentage \\
\hline Sand & 139 & 98.0 \\
\hline Rock & 0 & 0 \\
\hline Leaf litter & 2.83 & 2.00 \\
\hline Biologic soil crust & 0 & 0 \\
\hline Russian-thistle litter & & 0.20 \\
\hline Total gap length, in percent & & 82.8 \\
\hline Mean basal gap length, in centimeters & & 114 \\
\hline
\end{tabular}


Table 7. Vegetation cover and substrate measured in March 2012 in the study area near Teesto Wash, Navajo Nation, Arizona.-Continued

Site 2

\begin{tabular}{|c|c|c|}
\hline Vegetation & $\begin{array}{c}\text { Area, in square } \\
\text { meters }\end{array}$ & Percentage \\
\hline Mojave indigobush (Psorothamnus arborescens) & 10.9 & 7.70 \\
\hline Sandhill muhly (Muhlenbergia pungens) & 5.94 & 4.20 \\
\hline Rabbitbrush (Ericameria nauseosus) & 2.83 & 2.00 \\
\hline Indian ricegrass (Oryzopsis hymenoides) & 2.26 & 1.60 \\
\hline Shrub, unidentified, dead & 1.63 & 1.15 \\
\hline Russian thistle (Salsola sp.), dead & 1.36 & 0.96 \\
\hline Snakeweed (Gutierrezia sarothrae) & 0.81 & 0.57 \\
\hline Unidentified perennial grass & 0.79 & 0.56 \\
\hline Stickleaf (Mentzelia pumila) & 0.62 & 0.44 \\
\hline Giant dropseed (Sporobolus giganteus) & 0.11 & 0.08 \\
\hline Milkvetch (Astragalus sp.) & 0.02 & 0.01 \\
\hline Unidentified annual forb & 0.01 & 0.004 \\
\hline Unidentified annual forb; pigweed (Amaranthus sp.)? & 0.01 & 0.004 \\
\hline \multirow[t]{2}{*}{ Total vegetation cover } & 27.3 & 19.3 \\
\hline & $\begin{array}{c}\text { Area, in square } \\
\text { meters }\end{array}$ & Percentage \\
\hline Sand & 139 & 98.0 \\
\hline Rock & 0 & 0 \\
\hline Leaf litter & 2.83 & 2.00 \\
\hline Biologic soil crust & 0 & 0 \\
\hline Russian-thistle litter & 2.04 & 1.44 \\
\hline Total gap length, in percent & & 86.3 \\
\hline Mean basal gap length, in centimeters & & 267 \\
\hline
\end{tabular}


Table 7. Vegetation cover and substrate measured in March 2012 in the study area near Teesto Wash, Navajo Nation, Arizona.-Continued

Site 3

\begin{tabular}{|c|c|c|}
\hline Vegetation & $\begin{array}{l}\text { Area, in square } \\
\text { meters }\end{array}$ & Percentage \\
\hline Mojave indigobush (Psorothamnus arborescens) & 15.7 & 11.1 \\
\hline Rabbitbrush (Ericameria nauseosus) & 7.63 & 5.40 \\
\hline Stickleaf (Mentzelia pumila) & 3.87 & 2.74 \\
\hline Russian thistle (Salsola sp.), dead & 1.13 & 0.80 \\
\hline Unidentified perennial grass & 0.99 & 0.70 \\
\hline Snakeweed (Gutierrezia sarothrae), dead & 0.99 & 0.70 \\
\hline Indian ricegrass (Oryzopsis hymenoides) & 0.78 & 0.55 \\
\hline Unidentified annual forb; pigweed (Amaranthus sp.)? & 0.44 & 0.31 \\
\hline Giant dropseed (Sporobolus giganteus) & 0.28 & 0.20 \\
\hline Unidentified shrub, dead & 0.17 & 0.12 \\
\hline Unidentified annual forb & 0.12 & 0.08 \\
\hline Plains spring parsley (Cymopterus acaulis) & 0.003 & 0.002 \\
\hline Total vegetation cover & 32.1 & 22.7 \\
\hline Substrate & $\begin{array}{c}\text { Area, in square } \\
\text { meters }\end{array}$ & Percentage \\
\hline Sand & 137 & 96.7 \\
\hline Rock & 2.83 & 2.00 \\
\hline Leaf litter & 1.84 & 1.30 \\
\hline Biologic soil crust & 0 & 0 \\
\hline Russian-thistle litter & 2.01 & 1.42 \\
\hline Total gap length, in percent & & 68.9 \\
\hline Mean basal gap length, in centimeters & & 211 \\
\hline
\end{tabular}


Table 7. Vegetation cover and substrate measured in March 2012 in the study area near Teesto Wash, Navajo Nation, Arizona.-Continued

Site 4

\begin{tabular}{|c|c|c|}
\hline Vegetation & $\begin{array}{c}\text { Area, in square } \\
\text { meters }\end{array}$ & Percentage \\
\hline Mojave indigobush (Psorothamnus arborescens) & 22.9 & 16.2 \\
\hline Stickleaf (Mentzelia pumila) & 5.51 & 3.90 \\
\hline Rabbitbrush (Ericameria nauseosus) & 3.39 & 2.40 \\
\hline Russian thistle (Salsola sp.), dead & 3.14 & 2.22 \\
\hline Indian ricegrass (Oryzopsis hymenoides) & 1.10 & 0.78 \\
\hline Unidentified shrub, dead & 0.28 & 0.20 \\
\hline Unidentified perennial grass & 0.20 & 0.14 \\
\hline Giant dropseed (Sporobolus giganteus) & 0.14 & 0.10 \\
\hline Globemallow (Sphaeralcea sp.) & 0.11 & 0.08 \\
\hline Plains spring parsley (Cymopterus acaulis) & 0.10 & 0.07 \\
\hline Snakeweed (Gutierrezia sarothrae), dead & 0.07 & 0.05 \\
\hline Unidentified annual forb; pigweed (Amaranthus sp.)? & 0.07 & 0.05 \\
\hline Unidentified annual forb & 0.06 & 0.04 \\
\hline Bindweed heliotrope (Heliotropium convolvulaceum) & trace & trace \\
\hline Total vegetation cover & 37.1 & 26.2 \\
\hline Substrate & $\begin{array}{c}\text { Area, in square } \\
\text { meters }\end{array}$ & Percentage \\
\hline Sand & 139 & 98.3 \\
\hline Rock & 0 & 0 \\
\hline Leaf litter & 2.40 & 1.70 \\
\hline Biologic soil crust & 0 & 0 \\
\hline Russian-thistle litter & 1.84 & 1.30 \\
\hline Total gap length, in percent & & 83.9 \\
\hline Mean basal gap length, in centimeters & & 250 \\
\hline
\end{tabular}


Table 7. Vegetation cover and substrate measured in March 2012 in the study area near Teesto Wash, Navajo Nation, Arizona.-Continued

Site 5

\begin{tabular}{|c|c|c|}
\hline Vegetation & $\begin{array}{c}\text { Area, in square } \\
\text { meters }\end{array}$ & Percentage \\
\hline Mojave indigobush (Psorothamnus arborescens) & 8.20 & 5.80 \\
\hline Rabbitbrush (Ericameria nauseosus) & 5.80 & 4.10 \\
\hline Sandhill muhly (Muhlenbergia pungens) & 2.26 & 1.60 \\
\hline Stickleaf (Mentzelia pumila) & 1.84 & 1.30 \\
\hline Unidentified perennial grass & 1.61 & 1.14 \\
\hline Russian thistle (Salsola sp.), dead & 1.13 & 0.80 \\
\hline Indian ricegrass (Oryzopsis hymenoides) & 0.7 & 0.52 \\
\hline Snakeweed (Gutierrezia sarothrae) & 0.57 & 0.40 \\
\hline Unidentified shrub, dead & 0.28 & 0.20 \\
\hline Unidentified annual forb; pigweed (Amaranthus sp.)? & 0.15 & 0.10 \\
\hline Unidentified annual forb & 0.01 & 0.01 \\
\hline Total vegetation cover & 22.6 & 16.0 \\
\hline Substrate & $\begin{array}{l}\text { Area, in square } \\
\text { meters }\end{array}$ & Percentage \\
\hline Sand & 138 & 97.3 \\
\hline Rock & 0.28 & 0.20 \\
\hline Leaf litter & 3.53 & 2.50 \\
\hline Biologic soil crust & 0 & 0 \\
\hline Russian-thistle litter & 2.88 & 2.04 \\
\hline Total gap length, in percent & & 77.1 \\
\hline Mean basal gap length, in centimeters & & 222 \\
\hline
\end{tabular}


Table 7. Vegetation cover and substrate measured in March 2012 in the study area near Teesto Wash, Navajo Nation, Arizona.-Continued

Site 6

\begin{tabular}{|c|c|c|}
\hline Vegetation & $\begin{array}{l}\text { Area, in square } \\
\text { meters }\end{array}$ & Percentage \\
\hline Mojave indigobush (Psorothamnus arborescens) & 6.64 & 4.70 \\
\hline Stickleaf (Mentzelia pumila) & 2.12 & 1.50 \\
\hline Rabbitbrush (Ericameria nauseosus) & 1.56 & 1.10 \\
\hline Giant dropseed (Sporobolus giganteus) & 1.07 & 0.76 \\
\hline Unidentified shrub, dead & 0.71 & 0.50 \\
\hline Russian thistle (Salsola sp.), dead & 0.42 & 0.30 \\
\hline Indian ricegrass (Oryzopsis hymenoides) & 0.33 & 0.23 \\
\hline Unidentified perennial grass & 0.28 & 0.20 \\
\hline Plains spring parsley (Cymopterus acaulis) & 0.17 & 0.12 \\
\hline Unidentified annual forb & 0.14 & 0.10 \\
\hline Unidentified annual forb; pigweed (Amaranthus sp.)? & 0.06 & 0.04 \\
\hline Total vegetation cover & 13.5 & 9.6 \\
\hline Substrate & $\begin{array}{c}\text { Area, in square } \\
\text { meters }\end{array}$ & Percentage \\
\hline Sand & 139 & 98.2 \\
\hline Rock & 0.14 & 0.10 \\
\hline Leaf litter & 2.46 & 1.74 \\
\hline Biologic soil crust & 0 & 0 \\
\hline Russian-thistle litter & 0.14 & 0.10 \\
\hline Total gap length, in percent & & 73.8 \\
\hline Mean basal gap length, in centimeters & & 333 \\
\hline
\end{tabular}


Table 7. Vegetation cover and substrate measured in March 2012 in the study area near Teesto Wash, Navajo Nation, Arizona.-Continued

Site 7

\begin{tabular}{|c|c|c|}
\hline Vegetation & $\begin{array}{c}\text { Area, in square } \\
\text { meters }\end{array}$ & Percentage \\
\hline Rabbitbrush (Ericameria nauseosus) & 19.7 & 13.9 \\
\hline Mojave indigobush (Psorothamnus arborescens) & 8.62 & 6.10 \\
\hline Unidentified perennial grass & 2.21 & 1.56 \\
\hline Ephedra (Ephedra sp.) & 1.41 & 1.00 \\
\hline Russian thistle (Salsola sp.), dead & 1.27 & 0.90 \\
\hline Saltbush (Atriplex canescens) & 0.79 & 0.56 \\
\hline Sandhill muhly (Muhlenbergia pungens) & 0.71 & 0.50 \\
\hline Indian ricegrass (Oryzopsis hymenoides) & 0.57 & 0.40 \\
\hline Giant dropseed (Sporobolus giganteus) & 0.42 & 0.30 \\
\hline Snakeweed (Gutierrezia sarothrae) & 0.23 & 0.16 \\
\hline Stickleaf (Mentzelia pumila) & 0.20 & 0.14 \\
\hline Unidentified annual forb; pigweed (Amaranthus sp.)? & 0.12 & 0.08 \\
\hline Plains spring parsley (Cymopterus acaulis) & 0.06 & 0.04 \\
\hline \multirow[t]{2}{*}{ Total vegetation cover } & 36.3 & 25.6 \\
\hline & $\begin{array}{l}\text { Area, in square } \\
\text { meters }\end{array}$ & Percentage \\
\hline Sand & 125 & 88.7 \\
\hline Rock & 10.9 & 7.70 \\
\hline Leaf litter & 5.09 & 3.60 \\
\hline Biologic soil crust & 0 & 0 \\
\hline Russian-thistle litter & 5.09 & 3.60 \\
\hline Total gap length, in percent & & 73.4 \\
\hline Mean basal gap length, in centimeters & & 400 \\
\hline
\end{tabular}


Table 7. Vegetation cover and substrate measured in March 2012 in the study area near Teesto Wash, Navajo Nation, Arizona.-Continued

Site 8

\begin{tabular}{lcc}
\hline \multicolumn{1}{c}{ Vegetation } & $\begin{array}{c}\text { Area, in square } \\
\text { meters }\end{array}$ & Percentage \\
\hline Unidentified perennial grass & 11.10 & 7.85 \\
Russian thistle (Salsola sp.), dead & 1.81 & 1.28 \\
Unidentified forb, dead & 0.06 & 0.04 \\
Silverleaf nightshade (Solanum elaeagnifolium), dead & 0.03 & 0.02 \\
Globemallow (Sphaeralcea sp.) & 0.03 & 0.02 \\
Indian ricegrass (Oryzopsis hymenoides) & 0.01 & 0.01 \\
\hline Total vegetation cover & 13.0 & 9.2 \\
\hline \multicolumn{1}{c}{ Substrate } & Area, in square & Percentage \\
\hline Sand & meters & 89.2 \\
Rock & 126 & 5.44 \\
Leaf litter & 7.69 & 5.40 \\
Biologic soil crust & 7.63 & 0 \\
Russian-thistle litter & 0 & 0 \\
\hline Total gap length, in percent & 0 & 93.7 \\
\hline Mean basal gap length, in centimeters & & 333 \\
\hline
\end{tabular}


Table 7. Vegetation cover and substrate measured in March 2012 in the study area near Teesto Wash, Navajo Nation, Arizona._-Continued

Site 9

\begin{tabular}{|c|c|c|}
\hline Vegetation & $\begin{array}{c}\text { Area, in square } \\
\text { meters }\end{array}$ & Percentage \\
\hline Mojave indigobush (Psorothamnus arborescens) & 10.0 & 7.10 \\
\hline Unidentified shrub, dead & 2.26 & 1.60 \\
\hline Stickleaf (Mentzelia pumila) & 2.08 & 1.47 \\
\hline Rabbitbrush (Ericameria nauseosus), dead & 1.98 & 1.40 \\
\hline Rabbitbrush (Ericameria nauseosus), live & 0.99 & 0.70 \\
\hline Unidentified perennial grass & 0.14 & 0.10 \\
\hline Russian thistle (Salsola sp.), dead & 0.14 & 0.10 \\
\hline Unidentified annual forb; pigweed (Amaranthus sp.)? & 0.08 & 0.06 \\
\hline Indian ricegrass (Oryzopsis hymenoides) & 0.06 & 0.04 \\
\hline Unidentified perennial forb & 0.03 & 0.02 \\
\hline Unidentified annual forb & 0.003 & 0.002 \\
\hline Total vegetation cover & 17.8 & 12.6 \\
\hline Substrate & $\begin{array}{c}\text { Area, in square } \\
\text { meters }\end{array}$ & Percentage \\
\hline Sand & 103 & 72.6 \\
\hline Rock & 19.8 & 14.0 \\
\hline Leaf litter & 4.24 & 3.00 \\
\hline Biologic soil crust & 14.7 & 10.4 \\
\hline Russian-thistle litter & 3.53 & 2.50 \\
\hline Total gap length, in percent & & 75.9 \\
\hline Mean basal gap length, in centimeters & & 1,330 \\
\hline
\end{tabular}


Table 7. Vegetation cover and substrate measured in March 2012 in the study area near Teesto Wash, Navajo Nation, Arizona.-Continued

Site 10

\begin{tabular}{lcc}
\hline \multicolumn{1}{c}{ Vegetation } & $\begin{array}{c}\text { Area, in square } \\
\text { meters }\end{array}$ & Percentage \\
\hline Mojave indigobush (Psorothamnus arborescens) & 6.50 & 4.60 \\
Rabbitbrush (Ericameria nauseosus) & 6.08 & 4.30 \\
Stickleaf (Mentzelia pumila) & 2.97 & 2.10 \\
Unidentified shrub, dead & 0.85 & 0.60 \\
Russian thistle (Salsola sp.), dead & 0.42 & 0.30 \\
Unidentified perennial grass & 0.14 & 0.10 \\
Unidentified annual forb; pigweed (Amaranthus sp.)? & 0.12 & 0.09 \\
Indian ricegrass (Oryzopsis hymenoides) & 0.03 & 0.02 \\
Unidentified perennial forb & 0.01 & 0.01 \\
\hline Total vegetation cover & 17.1 & 12.1 \\
\hline \multicolumn{1}{c}{ Substrate } & Area, in square & Percentage \\
\hline meters & \\
\hline Sand & 112 & 79.2 \\
Rock & 26.0 & 18.4 \\
Leaf litter & 3.39 & 2.40 \\
Riologic soil crust & 0 & 0 \\
\hline Mean basal gap length, in centimeters & 0.14 & 0.10 \\
\hline
\end{tabular}


Table 7. Vegetation cover and substrate measured in March 2012 in the study area near Teesto Wash, Navajo Nation, Arizona.-Continued

Site 11

\begin{tabular}{|c|c|c|}
\hline Vegetation & $\begin{array}{l}\text { Area, in square } \\
\text { meters }\end{array}$ & Percentage \\
\hline Mojave indigobush (Psorothamnus arborescens) & 13.3 & 9.40 \\
\hline Stickleaf (Mentzelia pumila) & 1.92 & 1.36 \\
\hline Rabbitbrush (Ericameria nauseosus) & 1.70 & 1.20 \\
\hline Unidentified shrub, dead & 1.41 & 1.00 \\
\hline Indian ricegrass (Oryzopsis hymenoides) & 0.99 & 0.70 \\
\hline Giant dropseed (Sporobolus giganteus) & 0.42 & 0.30 \\
\hline Russian thistle (Salsola sp.), dead & 0.14 & 0.10 \\
\hline Unidentified aster (Asteraceae family), dead & 0.11 & 0.08 \\
\hline Unidentified annual forb; pigweed (Amaranthus sp.)? & 0.06 & 0.04 \\
\hline Unidentified perennial forb & 0.03 & 0.02 \\
\hline Total vegetation cover & 20.1 & 14.2 \\
\hline Substrate & $\begin{array}{l}\text { Area, in square } \\
\text { meters }\end{array}$ & Percentage \\
\hline Sand & 138 & 97.3 \\
\hline Rock & 0 & 0 \\
\hline Leaf litter & 3.53 & 2.50 \\
\hline Biologic soil crust & 0.28 & 0.20 \\
\hline Russian-thistle litter & 2.12 & 1.50 \\
\hline Total gap length, in percent & & 66.7 \\
\hline Mean basal gap length, in centimeters & & 333 \\
\hline
\end{tabular}

Produced in the Menlo Park Publishing Service Center, California Manuscript approved for publication, July 25, 2012 
